\title{
FUEL CELL BASED BATTERY-LESS UPS SYSTEM
}

\author{
A Thesis \\ by \\ MIRUNALINI VENKATAGIRI CHELLAPPAN \\ Submitted to the Office of Graduate Studies of \\ Texas A\&M University \\ in partial fulfillment of the requirements for the degree of \\ MASTER OF SCIENCE
}

August 2008

Major Subject: Electrical Engineering 


\title{
FUEL CELL BASED BATTERY-LESS UPS SYSTEM
}

\author{
A Thesis \\ by \\ MIRUNALINI VENKATAGIRI CHELLAPPAN
}

\author{
Submitted to the Office of Graduate Studies of \\ Texas A\&M University \\ in partial fulfillment of the requirements for the degree of \\ MASTER OF SCIENCE
}

\begin{abstract}
Approved by:
Chair of Committee, Prasad N. Enjeti

Committee Members, Chanan Singh

Shankar P. Bhattacharyya

Emil Straube

Head of Department, Costas N. Georghiades
\end{abstract}

August 2008

Major Subject: Electrical Engineering 


\author{
ABSTRACT \\ Fuel Cell Based Battery-less UPS System. \\ (August 2008)
}
Mirunalini Venkatagiri Chellappan, B.En, Anna University, Chennai, India Chair of Advisory Committee: Dr. Prasad N. Enjeti

With the increased usage of electrical equipment for various applications, the demand for quality power apart from continuous power availability has increased and hence requires the development of appropriate power conditioning system. A major factor during development of these systems is the requirement that they remain environment-friendly. This cannot be realized using the conventional systems as they use batteries and/or engine generators. Among various viable technologies, fuel cells have emerged as one of the most promising sources for both portable and stationary applications.

In this thesis, a new battery less UPS system configuration powered by fuel cell is discussed. The proposed topology utilizes a standard offline UPS module and the battery is replaced by a supercapacitor. The system operation is such that the supercapacitor bank is sized to support startup and load transients and steady state power is supplied by the fuel cell. Further, the fuel cell runs continuously to supply $10 \%$ power in steady state. In case of power outage, it is shown that the startup time for fuel cell is reduced and the supercapacitor bank supplies power till the fuel cell ramps up from supplying 
$10 \%$ load to $100 \%$ load. A detailed design example is presented for a $200 \mathrm{~W} / 350 \mathrm{VA} 1$ phase UPS system to meet the requirements of a critical load. The equivalent circuit and hence the terminal behavior of the fuel cell and the supercapacitor are considered in the analysis and design of the system for a stable operation over a wide range. The steady state and transient state analysis were used for stability verification.

Hence, from the tests such as step load changes and response time measurements, the non-linear model of supercapacitor was verified. Temperature rise and fuel consumption data were measured and the advantages of having a hybrid source (supercapacitor in parallel with fuel cell) over just a standalone fuel cell source were shown. Finally, the transfer times for the proposed UPS system and the battery based UPS system were measured and were found to be satisfactory. Overall, the proposed system was found to satisfy the required performance specifications. 


\section{DEDICATION}

To my dad, mom and brother

(Chellappan Ramasamy Gounder, Gunasundari Chellappan and Raghunath Chellappan)

Who mean the world to me 


\section{ACKNOWLEDGEMENTS}

I would firstly like to express my sincere gratitude to my advisor and mentor, Dr. Prasad Enjeti, for his guidance throughout my graduate studies. His wide technical knowledge, understanding, encouraging and personal guidance provided the strong basis for the completion of my thesis. I would like to thank all my committee members, Dr. Chanan Singh, Dr. Shankar Bhattacharyya and Dr. Emil Straube for their time, help and support.

I would also like to thank all my fellow students in the Power Electronics and Power Quality Laboratory at Texas A\&M University, especially Maja Harfman Todorovic and Leonardo Palma for their help and guidance. Also, I would like to thank my friends especially, Suresh Balasubramanian, Anand Balakrishnan and Haritha Eachempatti, who have been a great support morally and technically.

Finally, special thanks to my mother, father and brother for their love, support and encouragement. 


\section{TABLE OF CONTENTS}

Page

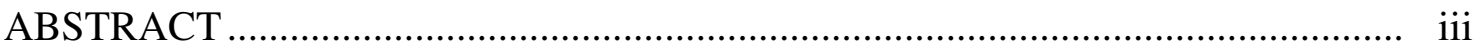

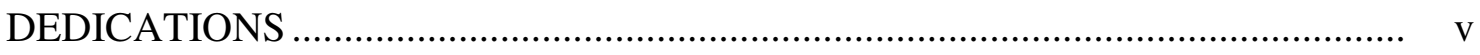

ACKNOWLEDGEMENTS ......................................................................... vi

TABLE OF CONTENTS ............................................................................ vii

LIST OF FIGURES ................................................................................ ix

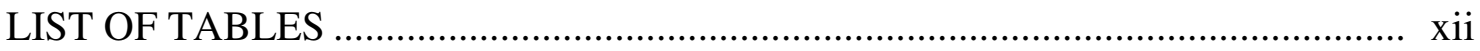

\section{CHAPTER}

I INTRODUCTION .................................................................. 1

$1.1 \quad$ Introduction ......................................................................... 1

$1.2 \quad$ Power quality disturbances................................................. 3

1.3 Possible solutions for power quality disturbances ....................... 5

$1.4 \quad$ Overview of UPS systems ................................................ 6

1.4.1 Passive standby UPS ..................................................... 7

1.4.2 Line interactive UPS .................................................... 8

1.4.3 Double conversion online UPS ............................................ 9

1.4.4 Delta conversion on-line UPS ............................................. 10

1.5 Disadvantages of battery based system and the alternatives available ............................................................................... 11

$1.6 \quad$ Fuel cell technology ......................................................... 13

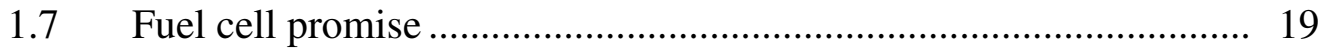

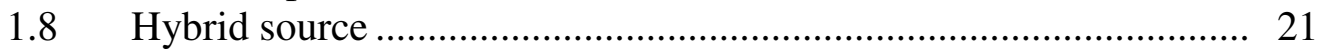

$1.9 \quad$ Fuel cell based battery-less UPS system .................................... 23

1.10 Previous work....................................................................... 24

1.11 Research objective................................................................ 26

1.12 Thesis outline ..................................................................... 27

II MODELING OF FUEL CELL AND SUPERCAPACITOR ............... 29

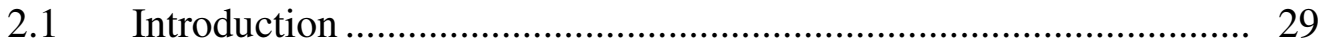

2.2 Equivalent circuit of fuel cell .............................................. 29 
CHAPTER Page

2.3 Non-linear model of supercapacitor ........................................ 35

2.4 Conclusions ....................................................................... 40

III PROPOSED FUEL CELL BASED BATTERY-LESS UPS SYSTEM . 41

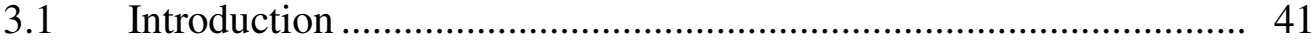

3.2 Block diagram of the proposed topology ................................. 42

$3.3 \quad$ Design example .............................................................. 44

3.3.1 Specifications of UPS ........................................................... 44

3.3.2 Fuel cell capacity ............................................................. 45

3.3.3 Supercapacitor sizing ..................................................... 47

3.3.4 Design of buck converter ................................................ 50

3.3.5 Design of supercapacitor charging circuit........................... 52

3.4 Losses in supercapacitor................................................ 54

3.5 Steady state stability analysis ................................................. 55

3.6 Transient state stability analysis.............................................. 57

3.7 Conclusions ................................................................... 64

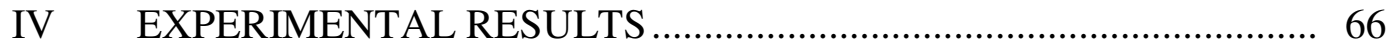

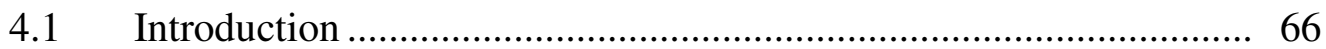

4.2 Experimental results for proposed UPS system .......................... 66

4.2.1 Transient response comparison of fuel cell and hybrid power

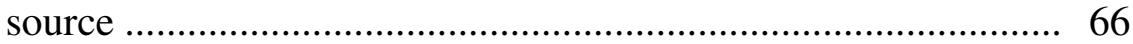

4.2.2 Fuel consumption ............................................................. 69

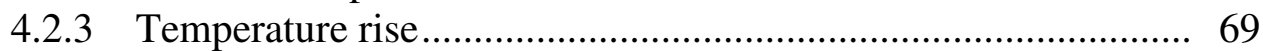

4.2.4 Performance of battery based and the proposed UPS systems... 71

4.3 Conclusions ........................................................................... 73

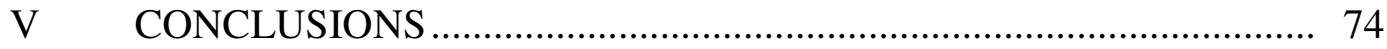

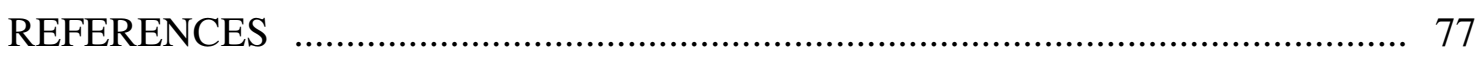

VITA 


\section{LIST OF FIGURES}

Page

Figure 1 ITI (CBEMA) curve (ITI, 2000) …........................................ 2

Figure 2 Sources and types of power quality disturbances......................... 5

Figure 3 Passive standby UPS topology …........................................... 7

Figure 4 Line interactive UPS topology ............................................. 8

Figure 5 Double conversion on-line UPS topology ................................ 10

Figure 6 Delta conversion on-line UPS topology .................................... 11

Figure 7 Comparison of efficiencies of fuel cells, diesel/steam engines and

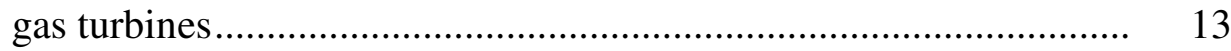

Figure $8 \quad$ Fuel cell basic structure ......................................................... 14

Figure 9 Block diagram of a fuel cell power system .................................. 15

Figure 10 Fuel cell and battery energy density vs. specific energy .................. 19

Figure 11 Typical cell voltage vs. current density plots for PEM fuel cells and a common interpretation for voltage drop.................................... 31

Figure 12 Equivalent circuit for PEM fuel cell ........................................ 31

Figure 13 Test setup for measuring the frequency respond of the PEM fuel cell

Figure 14 Nyquist plot for $1200 \mathrm{~W}$ fuel cell stack ..................................... 33

Figure 15 V-I curve for 1200W PEM fuel cell for power up to 200W ........... 34

Figure 16 Non-linear model of a supercapacitor ........................................ 35

Figure 17 Nyquist plot for sixteen Maxwell BCAP0140 supercapacitor ......... 37 
Figure 18 Resistance, R4 vs. charge voltage ..................................................... 39

Figure 19 Capacitance, $\mathrm{C} 4$ vs. charge voltage ................................................... 39

Figure 20 Block diagram of the proposed topology ......................................... 43

Figure 21 Ballard Nexa 1200W PEM fuel cell................................................. 45

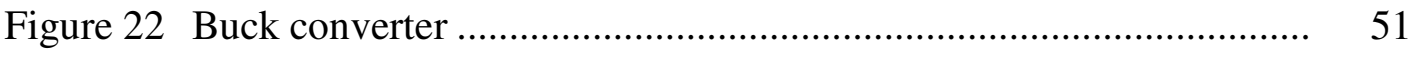

Figure 23 Supercapacitor charging circuit........................................................ 53

Figure 24 Supercapacitor discharge profile ...................................................... 54

Figure 25 Fuel cell V-I characteristic and load power locus ............................. 56

Figure 26 Fuel cell DC-DC converter system ……………………………..... 58

Figure 27 Modeling of fuel cell impedance effect............................................ 58

Figure 28 Small signal model of a) buck converter b) when fuel cell is

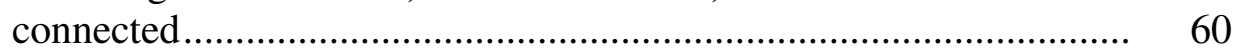

Figure 29 Impedances for fuel cell buck converter system ............................... 61

Figure 30 Small signal representation of fuel cell and supercapacitor powered system

Figure 31 Effect of forming hybrid source …………………………………... 64

Figure 32 Transient behavior of fuel cell and hybrid (fuel cell in parallel with supercapacitor) power sources for step change in load between $20 \mathrm{~W}$ and $200 \mathrm{~W}$ a) $20 \mathrm{~W}$ to $200 \mathrm{~W}$ with fuel cell power source; b) $200 \mathrm{~W}$ to $20 \mathrm{~W}$ with hybrid power source; c) $20 \mathrm{~W}$ to $200 \mathrm{~W}$ with hybrid power source; d) $200 \mathrm{~W}$ to $20 \mathrm{~W}$ with hybrid power source

Figure 33 Transient behavior of fuel cell and hybrid (fuel cell in parallel with supercapacitor) power sources for step change in load between $100 \mathrm{~W}$ and $200 \mathrm{~W}$ a) $100 \mathrm{~W}$ to $200 \mathrm{~W}$ with fuel cell power source; b) $200 \mathrm{~W}$ to $100 \mathrm{~W}$ with hybrid power source; c) $100 \mathrm{~W}$ to $200 \mathrm{~W}$ with hybrid power source; d) $200 \mathrm{~W}$ to $100 \mathrm{~W}$ with 
hybrid power source ......................................................... 68

Figure 34 Fuel consumption of a) $100 \mathrm{~W}$ load and b) $200 \mathrm{~W}$ load .................. 70

Figure 35 Temperature rise curve for a) $100 \mathrm{~W}$ load and b) $200 \mathrm{~W}$ load.......... 70

Figure 36 Transfer time for a) battery based UPS system with 20W load b) battery based UPS system with $100 \mathrm{~W}$ load c) proposed UPS system with $20 \mathrm{~W}$ load and d) proposed UPS system with $100 \mathrm{~W}$ load

Figure 37 CBEMA - ITIC curve showing the region of operation of the

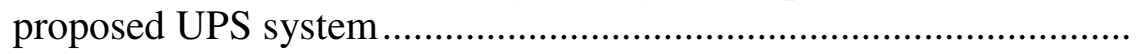




\section{LIST OF TABLES}

Page

Table I Cost of generating $1 \mathrm{~kW}$ of energy ......................................... 20

Table II Comparison of various backup systems ................................... 21

Table III Short and long term reserve energy sources for backup power ........ 22

Table IV Fuel Cell equivalent circuit parameters.................................... 34

Table V Supercapacitor equivalent circuit parameters ............................... 38

Table VI Nonlinear variation of supercapacitor equivalent model parameters .................................................................... 38

Table VII Specification of proposed fuel cell powered UPS ......................... 44

Table VIII Specifications of the Nexa fuel cell stack ................................. 45

Table IX Specification of supercapacitor, BCAP0140 E350 (Maxwell Technologies, 2000) ............................................................ 50

Table X Response times for step load changes for fuel cell and hybrid power source 


\section{CHAPTER I INTRODUCTION}

\subsection{Introduction}

In the present day, every application ranging from those used at home and small offices to hospitals, banks and huge call centers are dependent on electricity. Any power disturbance such as power outage or voltage sag/swell can result in malfunctioning of the equipment, loss in productivity and data and in the case of health care, loss of lives is also possible. Hence, power quality and power continuity are important factors that need to be ensured for critical applications. There exists an intrinsic relationship between the load performance and the electric power quality. Power outages and other power disturbances cannot be avoided but a system can be developed to ensure that the load does not see these power disturbances.

In view of this, various power conditioners such as surge suppressors, stabilizers and Uninterruptible Power Supply (UPS) systems have been designed. A reference for developing these power conditioners is a CBEMA curve (Figure 1) which is a representation of the events of allowed voltage variations with time. This curve gives the AC input voltage envelope that typically can be tolerated by the Information Technology Equipment [1] as a function of time. The methods by which this curve may be

This thesis follows the style of IEEE Transactions on Industry Applications. 


\section{ITI (CBEMA) Curve}

(Revised 2000)

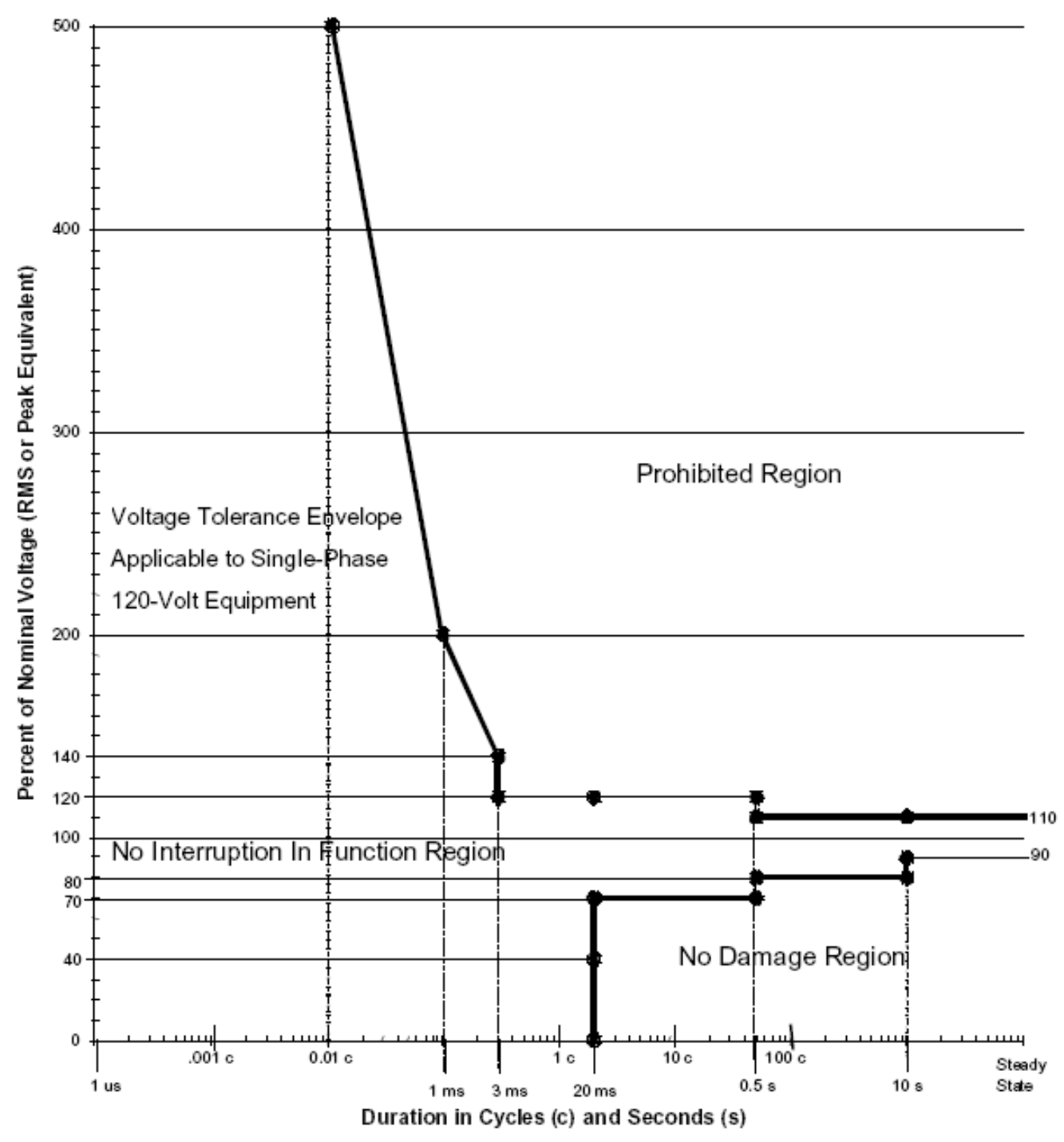

Figure 1. ITI (CBEMA) curve (ITI, 2000)

maximized so as to supply quality power for longer durations of time have been one of the major goals of the power conditioning systems. While aiming towards these goals, another factor to be considered is achieving these while staying environmentally friendly. With batteries as the major means of storing back up energy, this is not 
possible. (Batteries and their disadvantages have been discussed later in this chapter). Hence, an eco-friendly means of storing/generating energy has been the goal. One of the steps towards this goal is the usage of fuel cells as the means of providing the back up energy required. In the recent years, people have become more aware of the need and advantages of using fuel cells. The fuel cell technology and its advantages have been discussed in Section 1.6.

\subsection{Power quality disturbances}

The study of the different power quality disturbances, their effects on the equipment and the frequency of occurrence is important for arriving at the most appropriate and optimized solution for these disturbances. The common power quality disturbances faced are voltage surges, spikes and sags and harmonics (or noise) in the power line. These disturbances have been explained below [2]:

1. Surges: Surge is a rapid short-term increase in voltage. Surges are often caused when high power demand devices such as air conditioners turn off and the extra voltage is dissipated through the power line. Since sensitive electronic devices require a constant voltage, surges stress delicate components and cause premature failure.

2. Spikes: An extremely high and nearly instantaneous increase in voltage within a very short duration measured in microseconds is called a spike. Spikes are often caused by lightning or by events such as power coming back on after an outage. A spike can damage or destroy sensitive electronic equipment. 
3. Sag: A rapid short-term decrease in voltage is sag. Sag typically is caused by simultaneous high power demand of many electrical devices such as motors, compressors and so on. The effect of sag is to "starve" electronic equipment of power causing unexpected crashes and lost or corrupted data. Sags also reduce the efficiency and life span of equipment such as electric motors.

4. Noise: Noise is a disturbance in the smooth flow of electricity. Often technically referred to as electro-magnetic interference (EMI) or radio frequency interference (RFI). "Harmonics" are a special category of power line noise that causes distortions in electrical voltage or current. It is the presence of voltage/current components whose frequencies are multiples of the fundamental frequency. These are caused by the non-linear power requirement of the load. Noise can be caused by motors and electronic devices in the immediate vicinity or far away. Noise can affect performance of some equipment and introduce glitches and errors into software programs and data files. Harmonics cause alteration in the rms, peak and average values of the power demanded by the load hence causing an increase in the power drawn.

5. Outage: Outage is the total loss of power for some period of time. Outages are caused by excessive demands on the power system, lightning strikes and accidental damage to power lines. In addition to shutting down all types of electrical equipment, outages cause unexpected data loss. 
The various sources of power quality disturbances have been shown in Figure 2 which shows that a major percentage of the disturbance is caused due to the equipment used in business or a facility. Hence it is vital to protect the equipment as well as the utility from such disturbances. The possible solutions have been explained in the next section.
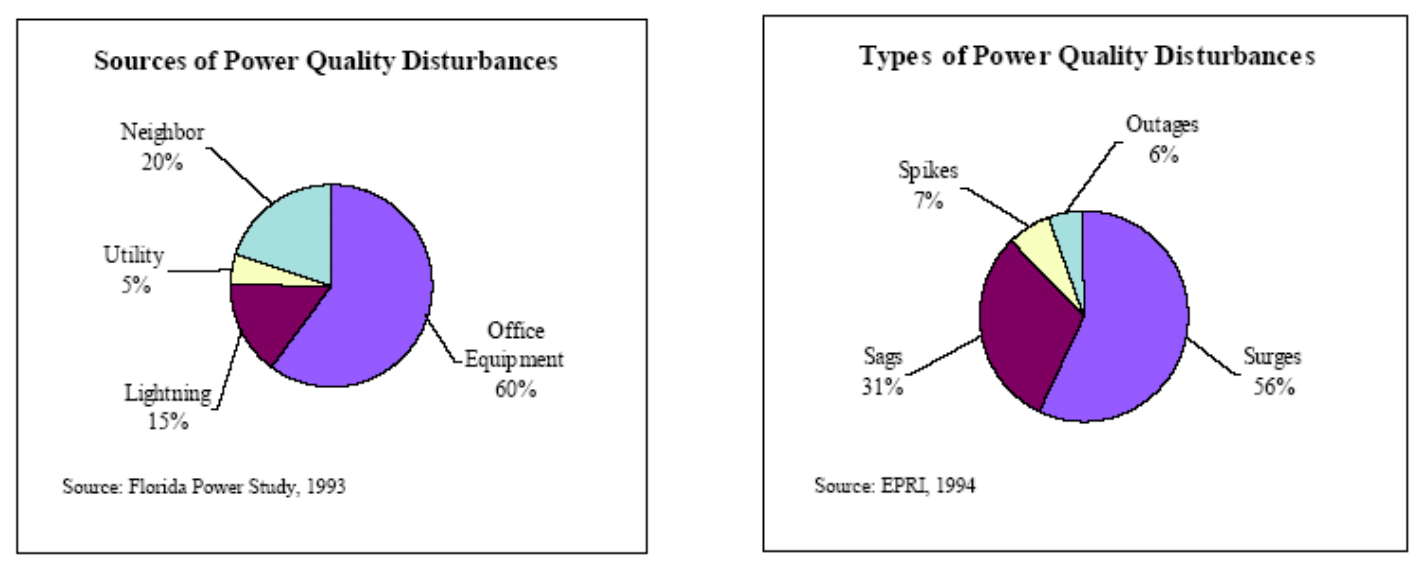

Figure 2. Sources and types of power quality disturbances

\subsection{Possible solutions for power quality disturbances}

The most common solutions for the above mentioned power quality disturbances are surge suppressors, stabilizers and UPS (Uninterruptible Power Supply) systems.

A surge suppressor is an electronic device that limits the damaging effect of power surges on electronic equipment from commercial power plants, generators, and electrical storms. A surge protector passes the electrical current along from the outlet to a number of electrical and electronic devices plugged in to the power strip. In case of voltage surge or spike, the surge protector attempts to regulate the voltage either by blocking or shorting to ground voltages above a safe threshold. 
Stabilizer is a mains regulator which uses a continuously variable autotransformer to maintain an AC output that is as close to the standard or normal mains voltage as possible, under conditions of fluctuation. It uses a servomechanism (or negative feedback) to control the position of the tap (or wiper) of the autotransformer, usually with a motor. An increase in the mains voltage causes the output to increase, which in turn causes the tap (or wiper) to move in a direction that reduces the output towards the nominal voltage.

An Uninterruptible Power Supply (UPS) system is a device which ensures quality and continuous power supply to the connected equipment by supplying power from a separate source. The backup source may be battery, flywheel, generator or more recently, fuel cells and supercapacitors. While stabilizers and surge suppressors provide protection against surges, spikes and noise only, UPS system also takes care of voltage sags and power outages. Hence, UPS system is the ideal solution for equipment protection hence forms the base for this research.

\subsection{Overview of UPS systems}

An UPS system basically has three components - rectifier, inverter and back up power system. The backup energy system can be batteries, flywheel, engine generator, fuel cells and/or supercapacitors.

Depending on the design approach and the performance characteristics, there are four common types of UPS systems [3]-[5]:

1. Passive standby

2. Line interactive 
3. Double conversion on-line

4. Delta conversion on-line

\subsubsection{Passive standby UPS}

This topology, shown in Figure 3, is also known as "Off-line UPS" or "Line-Preferred UPS".

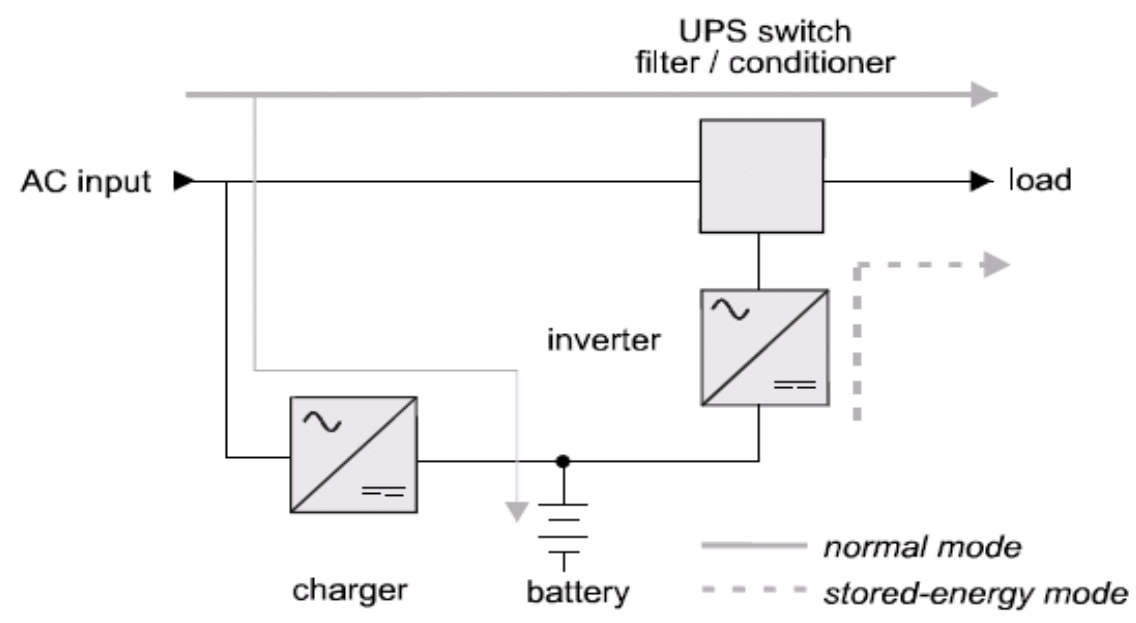

Figure 3. Passive standby UPS topology

Passive standby UPS system is used for low power ratings $(<2 \mathrm{kVA})$ and is most commonly used for Personal Computers. In normal mode of operation, the load is supplied from the utility through a static switch, generally via a filter/conditioner to mitigate the disturbances and to provide voltage regulation. During this mode, the $\mathrm{AC} / \mathrm{DC}$ converter (charger) charges the energy storage device. In the stored-energy mode of operation, i.e. when the input line is outside the preset tolerance limits or is not present at all, the load is supplied from the energy storage device through the inverter. The main advantages of this topology are simple design, low cost and small size. The 
major drawbacks are that there is no isolation from the distribution system, long switching time and no regulation of output frequency and voltage.

\subsubsection{Line-interactive UPS}

Line-interactive UPS system is used in low power ratings such as for small business, web and departmental servers. This topology (shown in Figure 4) consists of a static switch, a bidirectional converter and the energy storage device. A line-interactive UPS interacts with the line and operates either to improve the power factor or to regulate the output voltage for the load. This UPS has three modes of operation. In the normal mode of operation, the utility feeds the load directly and the bidirectional converter is operated in order to maintain the power factor close to unity and provide conditioned power to the load. In the stored-energy mode of operation, the static switch breaks the connection from the utility to prevent back-feed from the inverter. The converter acts as an inverter to supply power to the load from the energy storage device. This type of UPS may include a maintenance bypass, during which the UPS is totally switched off and the load is supplied from the utility.

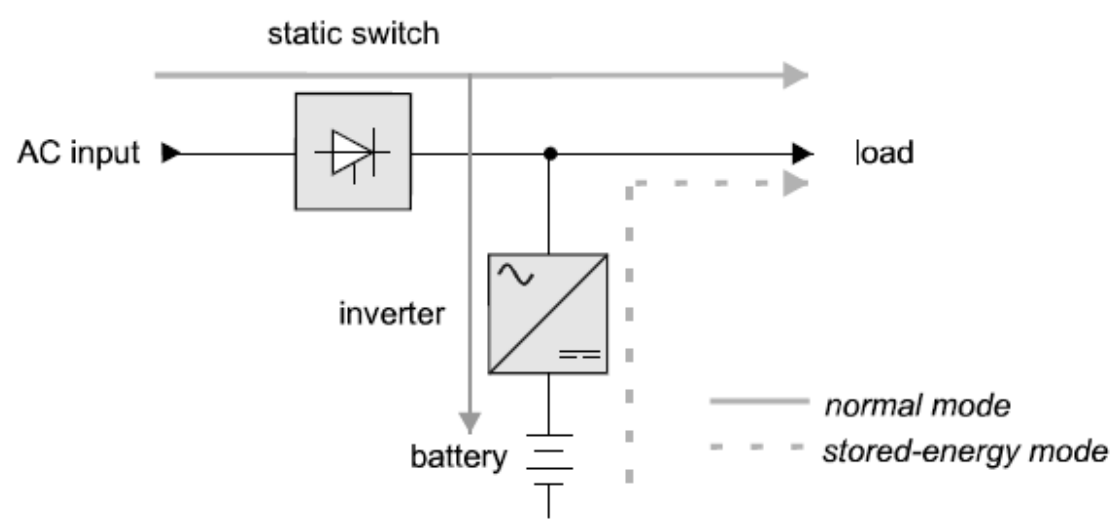

Figure 4. Line interactive UPS topology 
The advantages of the line-interactive UPS systems are simple design, high reliability and lower cost compared to double conversion UPS systems. The main disadvantages of this system are no isolation of the load from the distribution system, no regulation of output frequency, mediocre output voltage conditioning and poor efficiency. As frequency regulation is not possible it is poorly suited to sensitive loads with medium to high power ratings.

\subsubsection{Double conversion on-line UPS}

Double conversion UPS systems are used exclusively for protection of critical application of higher power ratings (from $10 \mathrm{kVA}$ and upwards). During the normal mode of operation, the power to the load is supplied via the rectifier/charger and inverter. Here, a double conversion - AC/DC and DC/AC, takes place. These are also known as "On-Line UPS" or "Inverter-Preferred UPS". This topology, shown in Figure 5) allows good line conditioning as the two converters can be operated to provide the required voltage and frequency. The $\mathrm{AC} / \mathrm{DC}$ converter charges the battery or the energy storage element that is present there.

During the stored energy mode, the energy storage device and the DC/AC converter provide the required power. When the AC line resumes, the input and output voltages are synchronized using an appropriate control loop. In the bypass mode of operation, the load is transferred without a break to the AC bypass when there is UPS internal malfunction, load current transients, overloads or end of battery backup time. There is also a separate maintenance bypass switch which is operated manually and is used for maintenance purpose. Continuous protection of load, isolation of load from the 
distribution system, improved performance under steady state and transient conditions, good line conditioning are some of the advantages of this UPS system. The main drawback of this topology is that it is expensive.

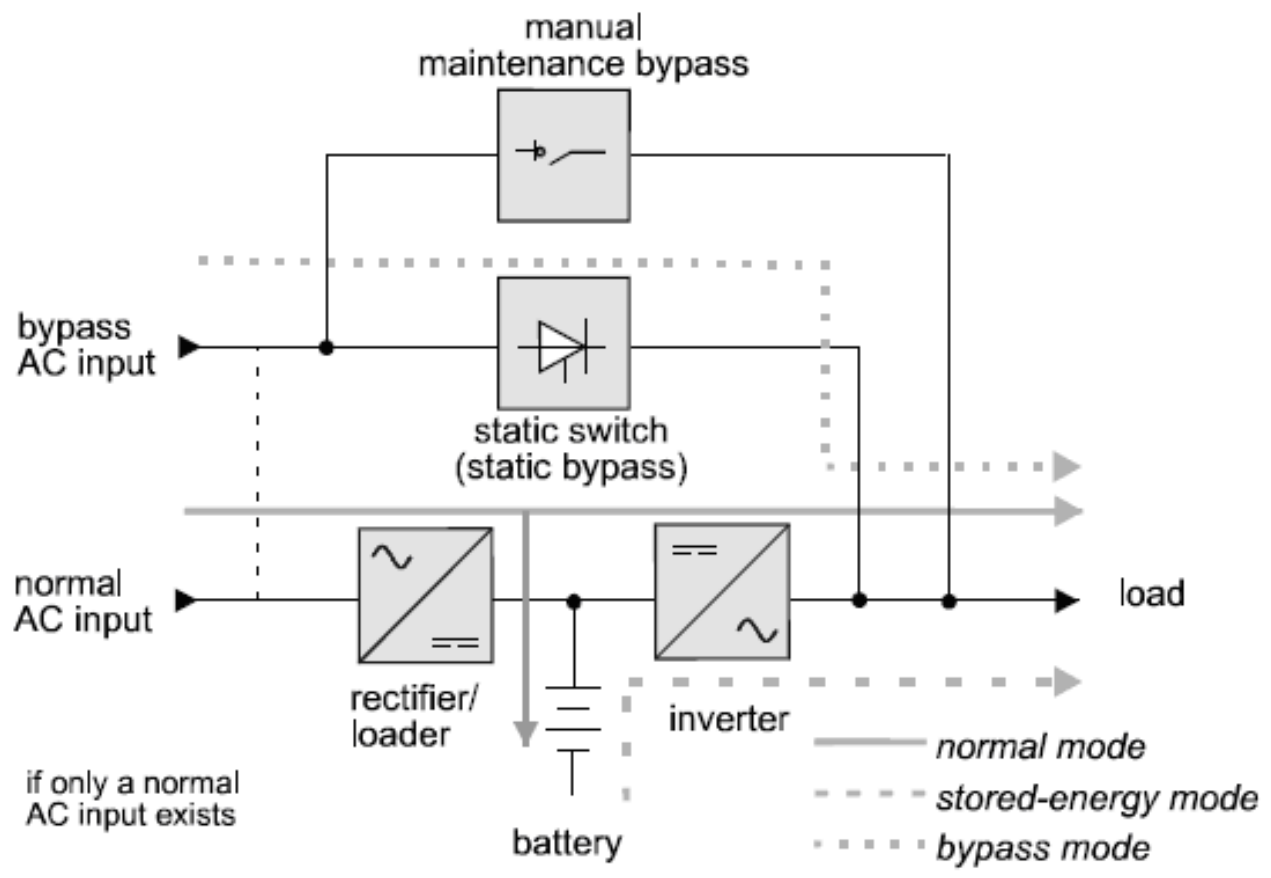

Figure 5. Double conversion on-line UPS topology

\subsubsection{Delta conversion on-line UPS}

This UPS topology is a newer technology which overcomes the drawbacks of Double conversion UPS and is used for $5 \mathrm{kVA}$ to $1.6 \mathrm{MW}$ applications. The topology is shown in Figure 6. During normal mode of operation, similar to the double conversion UPS system, the delta conversion UPS system also has its inverter supplying the load voltage. The variation here is that the delta converter also supplies power to the inverter output. In case of power failure or disturbances, the operation is the same as the double conversion UPS system. 


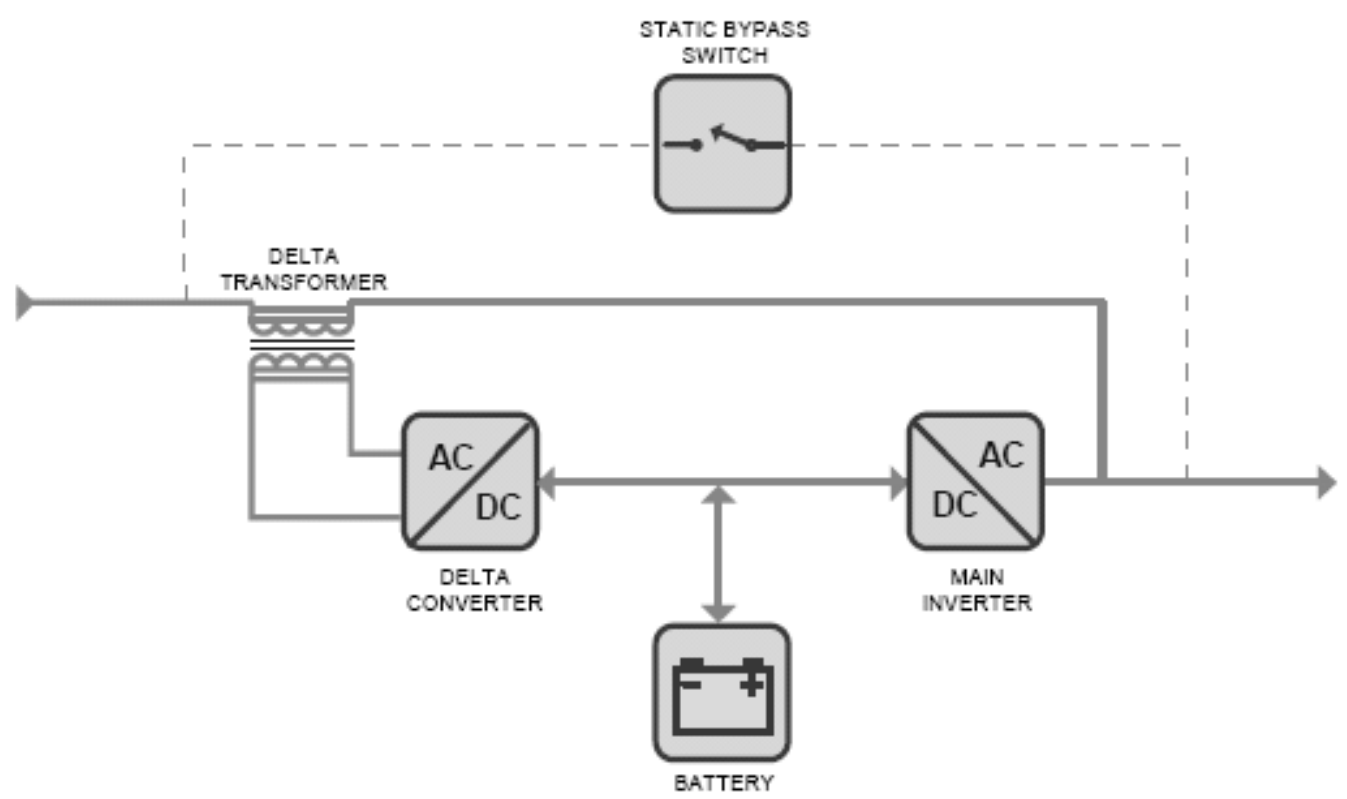

Figure 6. Delta conversion on-line UPS topology

\subsection{Disadvantages of battery based system and the alternatives available}

A typical UPS system uses Sealed Lead Acid (SLA) batteries as the means of energy storage. Though they have the obvious advantages of being inexpensive, reliable and mature technology, low self discharge and low maintenance requirements compared to other battery technologies, there are some disadvantages which propel the search for better ways of storing energy.

SLA batteries require slow charging for longer life and more reliable operation. The reason is as follows: A SLA battery consists of lead electrodes and lead oxide electrode with some amount of sulphuric acid. When these batteries are charged or discharged, the reacting chemicals present in the interface between the electrode and electrolyte get affected first. An interface charge is first created which diffuses over the entire volume of the active material. When a SLA battery is completely discharged and 
given a fast charge, the interface charge is only created first and this charge will spread throughout the battery thus causing the net interface charge to decrease. This will cause trouble when the initial current required by the system is very high. When the batteries are slowly charged, there is enough time for the interface charge to redistribute and get replenished by the charger. Hence, slow charging of the batteries is essential for their proper functioning and longevity.

Also care must be taken while charging as too high a rate of charging can lead to thermal runaway, rupture or internal mechanical damage.

SLA batteries have to be stored in charged state always. This is because a discharged battery will lead to freezing of its electrolyte. Also, leaving them charged and unused for large periods of time will lead to deep discharge and subsequent irreversible capacity loss.

The major drawback of SLA batteries is their very poor energy densities which makes them heavy and occupy a huge amount of space which renders limited usage in stationary and wheeled applications.

Another major shortcoming of lead-acid batteries is that they are environmentally unfriendly due to the electrolyte and the lead content. Hence most SLA batteries are recycled. Also, while transporting flooded lead acid batteries extreme precautions have to be taken to avoid spillage in case of an accident.

Due to above problems associated with usage of batteries, better solutions for backup power and energy storage have been explored and elaborated on in forthcoming sections. 


\subsection{Fuel cell technology}

Fuel cell is an energy conversion device that uses an electrochemical process to convert hydrogen into electricity without combustion. As long as fuel is supplied, the fuel cell will continue to generate power. Since the conversion of the fuel to energy takes place via an electrochemical process, not combustion, the process is clean, quiet and highly efficient - two to three times more efficient than fuel burning (as shown in Figure 7). Fuel cells are similar to batteries but the fuel and oxidant are stored externally, enabling them to continue operating as long as the chemicals are supplied. In most applications the oxygen is taken directly from air, so that only the fuel has to be stored. The ideal fuel for fuel cells is hydrogen, but other hydrogen containing fuels (such as natural gas or petrol) may be used if they are passed through a reformer, which converts them into a hydrogen rich gas.

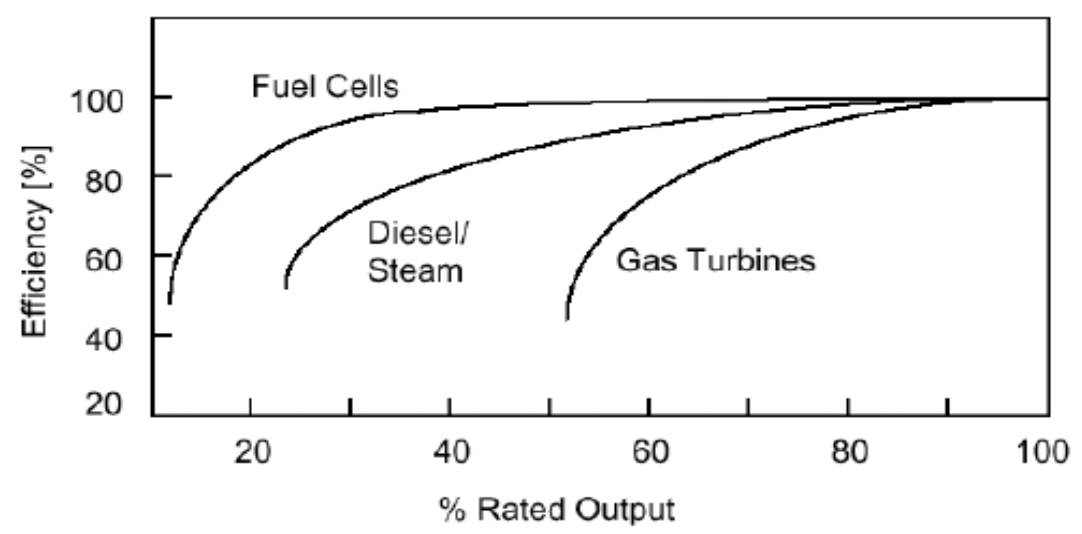

Figure 7. Comparison of efficiencies of fuel cells, diesel/steam engines and gas turbines

A fuel cell consists of two electrodes, an anode and a cathode, with an electrolyte sandwiched in between Figure 8 is a diagram of a typical fuel cell. Oxygen passes over 
the cathode and hydrogen over the anode. When the two gases try to interact, the presence of electrolyte splits the hydrogen atom into a proton and an electron. The proton passes freely through the electrolyte. The electron travels through the electrical circuit, creating an electric current before recombining with the hydrogen and oxygen, creating a molecule of water. This chemical process generates electrical and thermal energy but produces pure water as a by-product.

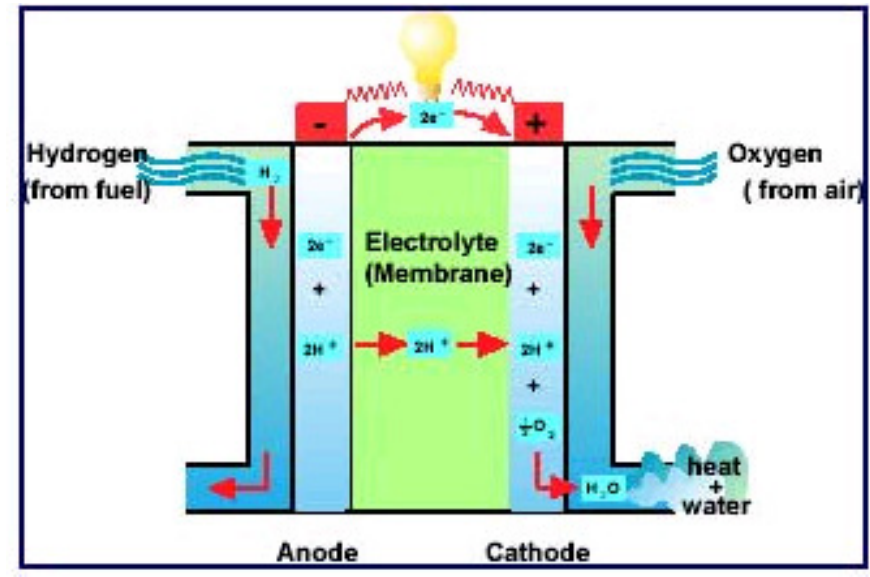

Figure 8. Fuel cell basic structure

As shown in Figure 9, a fuel cell system consists of three main components that work together: a fuel reformer, a fuel cell stack consisting of many membrane electrode assemblies, with gas and water distribution manifolds and electronic controls and power conversion equipment. The reformer is responsible for producing a hydrogen-rich stream, typically from a fossil fuel source, which is then fed into the stack containing the membrane assembly to be combined with oxygen from the air. This catalytic reactive combination of hydrogen and oxygen produces electricity. Reformers can be designed to convert a number of everyday fuels into hydrogen, including natural gas, propane, coal- 
bed gas (sour gas), landfill decomposition gas, and gasoline. The reformer converts the hydrogen from the hydrocarbon molecule, generally using the steam or heat captured from the operating fuel cell. Alternatively, hydrogen can be produced in bulk at a separate facility and then transported and stored on site in a compressed gas form or bound in a metal hydride.

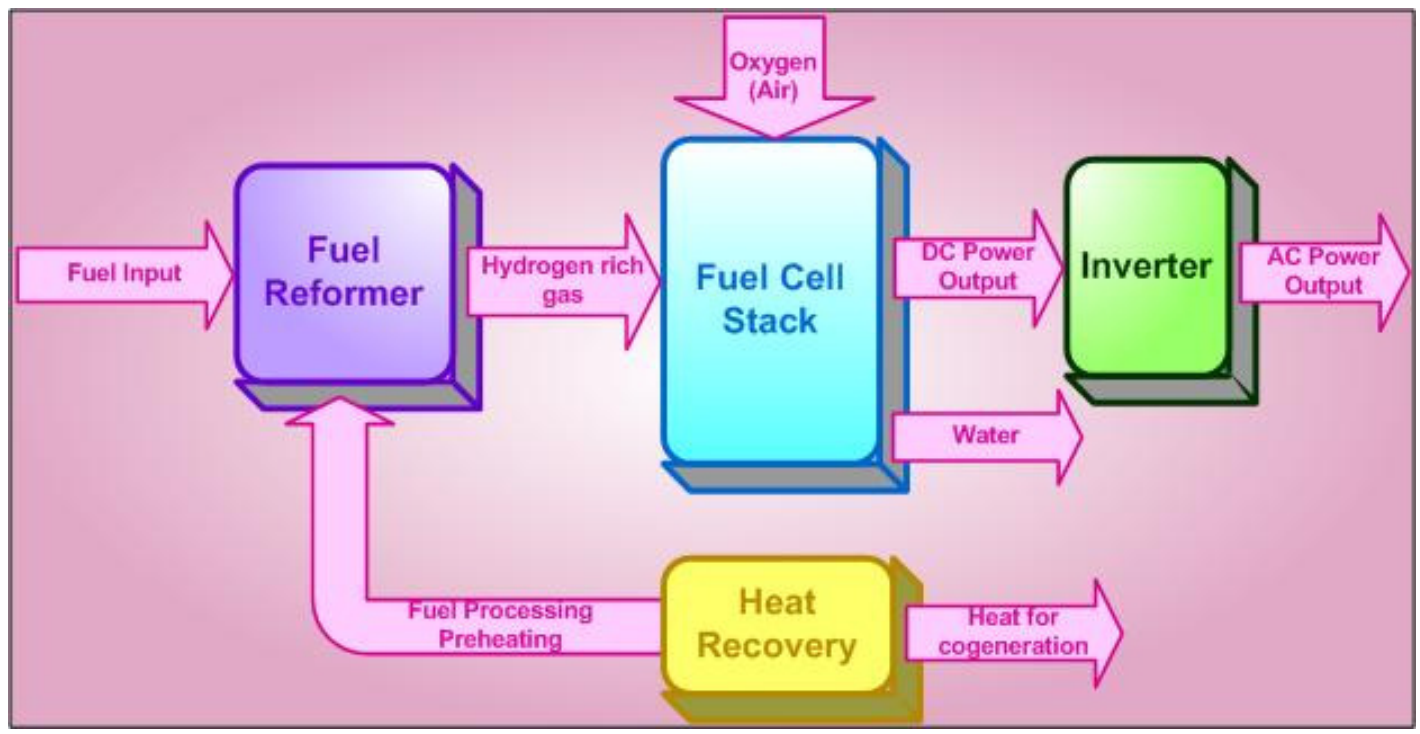

Figure 9. Block diagram of a fuel cell power system

The heart of the fuel cell is the membrane electrode assembly, composed of an anode, cathode, electrolyte, and associated channels to deliver hydrogen and oxygen and to remove water and heat. The anode and cathode have to be electrically isolated from each other, but with a membrane in between them that allows hydrogen ions catalytically produced at the anode to migrate to the cathode to combine with oxygen from the air, producing water. The electric current flows from one electrode to the other through the electrical load. The fuel cell system (Figure 9) contains a fuel cell stack, so called because it is a stack of the fuel cells shown in (Figure 8). The size of the stack 
determines how much power and voltage can be produced by the system. The third part of a fuel cell system consists of the electronic controls and power conversion equipment. Integral to efficient design, electronic controls balance the inflows and outflows of fuel, air, and cooling agents. Power conditioning equipment is also needed to convert the direct current (DC) power produced by fuel cells into the appropriate power demand by the load. This process is represented by the inverter box in Figure 9.

Fuel cells can be classified into five main types each depending on the type of electrolyte and fuel used.

1. Alkali fuel cells (AFC) operate on compressed hydrogen and oxygen. They generally use a solution of potassium hydroxide (chemically, $\mathrm{KOH}$ ) in water as their electrolyte. Efficiency is about $70 \%$, and operating temperature is 150 to $200{ }^{\circ} \mathrm{C}$, (about 300 to $400{ }^{\circ} \mathrm{F}$ ). Cell output ranges from $300 \mathrm{~W}$ to 5 $\mathrm{kW}$. Alkali cells were used in Apollo spacecraft to provide both electricity and drinking water. They require pure hydrogen fuel, however, and their platinum electrode catalysts are expensive. And like any container filled with liquid, they can leak.

2. Molten Carbonate fuel cells (MCFC) use high-temperature compounds of salt (like sodium or magnesium) carbonates (chemically, $\mathrm{CO}_{3}$ ) as the electrolyte. Efficiency ranges from 60 to $80 \%$, and operating temperature is about $650{ }^{\circ} \mathrm{C}\left(1,200{ }^{\circ} \mathrm{F}\right)$. Units with output up to $2 \mathrm{MW}$ have been constructed, and designs exist for units up to $100 \mathrm{MW}$. The high temperature limits damage from carbon monoxide "poisoning" of the cell and waste heat 
can be recycled to make additional electricity. Their nickel electrodecatalysts are inexpensive compared to the platinum used in other cells. But the high temperature also limits the materials and safe uses of MCFCs-they would probably be too hot for home use. Also, carbonate ions from the electrolyte are used up in the reactions, making it necessary to inject carbon dioxide to compensate.

3. Phosphoric Acid fuel cells (PAFC) use phosphoric acid as the electrolyte. Efficiency ranges from 40 to $80 \%$, and operating temperature is between 150 to $200{ }^{\circ} \mathrm{C}$ (about 300 to $400{ }^{\circ} \mathrm{F}$ ). Existing phosphoric acid cells have outputs up to $200 \mathrm{~kW}$, and $11 \mathrm{MW}$ units have been tested. PAFCs tolerate a carbon monoxide concentration of about $1.5 \%$, which broadens the choice of fuels they can use. If gasoline is used, the sulfur must be removed. Platinum electrode-catalysts are needed, and internal parts must be able to withstand the corrosive acid.

4. Proton Exchange Membrane fuel cells (PEMFC) work with a polymer electrolyte in the form of a thin, permeable sheet. Efficiency is about 40 to 50 $\%$, and operating temperature is about $80{ }^{\circ} \mathrm{C}$ (about $175{ }^{\circ} \mathrm{F}$ ). Cell outputs generally range from 50 to $250 \mathrm{~kW}$. The solid, flexible electrolyte will not leak or crack and these cells operate at a low enough temperature to make them suitable for homes and cars. But their fuels must be purified, and a platinum catalyst is used on both sides of the membrane, raising costs. 
5. Solid Oxide fuel cells (SOFC) use a hard, ceramic compound of metal (like calcium or zirconium) oxides (chemically, $\mathrm{O}_{2}$ ) as electrolyte. Efficiency is about $60 \%$, and operating temperatures are about $1,000{ }^{\circ} \mathrm{C}$ (about $1,800{ }^{\circ} \mathrm{F}$ ). Cells output is up to $100 \mathrm{~kW}$. At such high temperatures a reformer is not required to extract hydrogen from the fuel, and waste heat can be recycled to make additional electricity. However, the high temperature limits applications of SOFC units and they tend to be rather large. While solid electrolytes cannot leak, they can crack.

Of the above mentioned fuel cell types, Proton Exchange Membrane fuel cell generate more power for a given volume or weight of fuel cell. This high-power characteristic makes them compact and lightweight. Also, the operating temperature is less than $100^{\circ} \mathrm{C}$, which allows rapid start-up. The solid electrolyte has many advantages such as - the sealing of the anode and cathode gases is simpler hence is lesser expensive to manufacture, more immune to difficulties with orientation, fewer problems with corrosion which lead to longer cell and stack life. Due to the above advantages, PEMFCs are most commonly used in vehicular and other commercial applications.

The fuel for the PEMFC is hydrogen and the charge carrier is the hydrogen ion (proton). At the anode, the hydrogen molecule is split into hydrogen ions (protons) and electrons. The hydrogen ions permeate across the electrolyte to the cathode while the electrons flow through an external circuit and produce electric power. Oxygen, usually in the form of air, is supplied to the cathode and combines with the electrons and the hydrogen ions to produce water. The reactions at the electrodes are as follows: 
Anode Reactions: $2 \mathrm{H}_{2}=>4 \mathrm{H}++4 \mathrm{e}-$

Cathode Reactions: $\mathrm{O}_{2}+4 \mathrm{H}++4 \mathrm{e}-=>2 \mathrm{H}_{2} \mathrm{O}$

Overall Cell Reactions: $2 \mathrm{H}_{2}+\mathrm{O}_{2}=>2 \mathrm{H}_{2} \mathrm{O}$

The voltage produced by a single PEMFC varies from $1.4 \mathrm{~V}$ at no load to $0.7 \mathrm{~V}$ at nominal load current. Thus, in order to obtain a reasonable voltage a number of individual cells need to be stacked in series. However stacking multiple cells in series has the disadvantage of increasing the complexity of the system.

\subsection{Fuel cell promise}

Some of the main advantages of PEM fuel cells are their high efficiency, simple operation and high energy density. These are the reasons, especially the later, why fuel cells appear as a direct competition for traditional power sources for portable electronics.

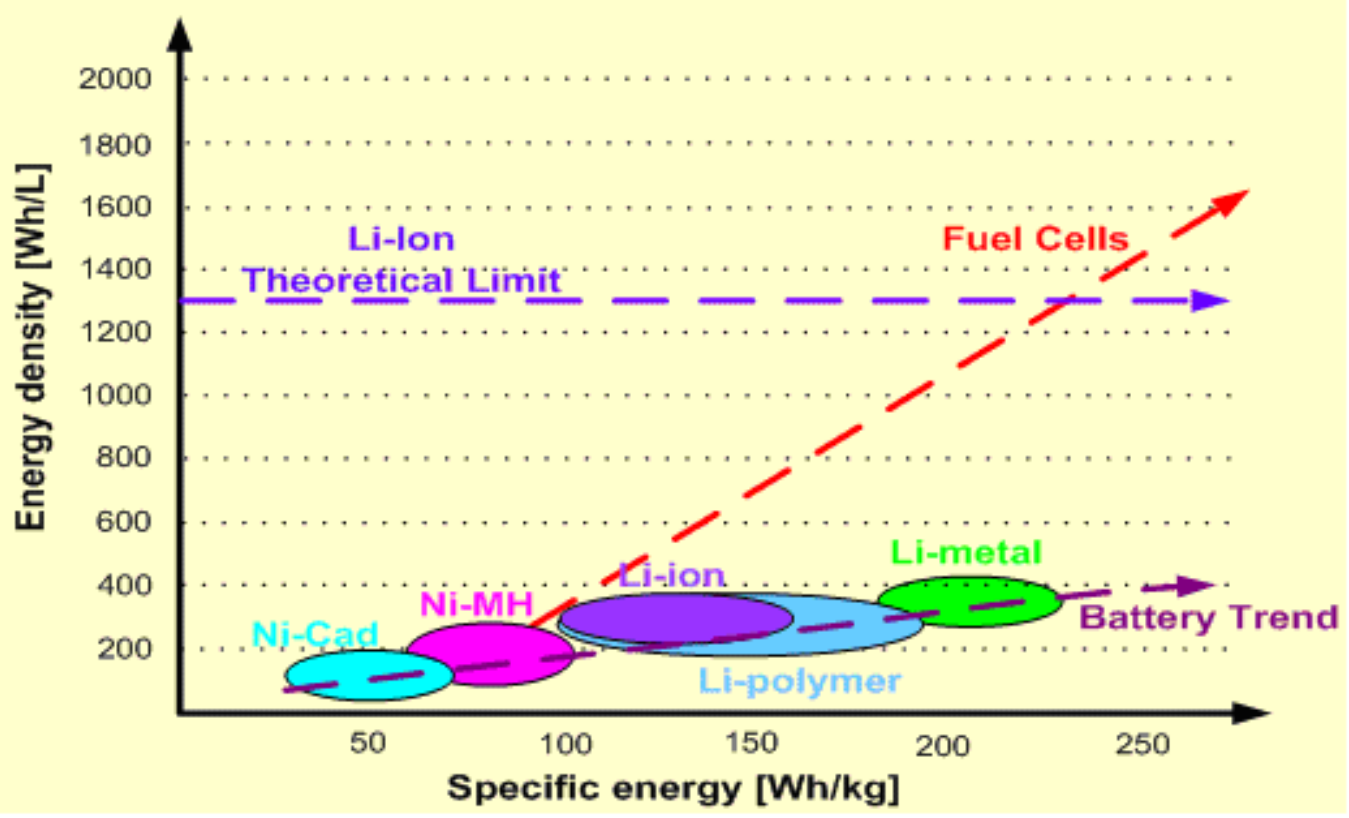

Figure 10. Fuel cell and battery energy density vs. specific energy 
Since the introduction of portable electronics in the mid 1950's batteries have been their de facto source of energy. However the amount of energy that can be stored in batteries is limited and their development does not keep up with the energy requirements of modern devices. In contrast the energy density of fuel cells up to 4 times higher than that of batteries currently available as can be observed from Figure 10. Moreover fuel cells offer an energy density even higher that the theoretical limit of their closes competitor (Li-ion).

Table I Cost of generating $1 \mathrm{~kW}$ of energy

\begin{tabular}{|c|c|c|c|c|}
\hline $\begin{array}{l}\text { Power } \\
\text { source }\end{array}$ & $\begin{array}{l}\text { Investment of } \\
\text { equipment to } \\
\text { generate } 1 \mathrm{~kW}\end{array}$ & $\begin{array}{l}\text { Lifespan of } \\
\text { equipment before } \\
\text { major overhaul or } \\
\text { replacement }\end{array}$ & $\begin{array}{c}\text { Cost of fuel } \\
\text { per } k W h\end{array}$ & $\begin{array}{c}\text { Total cost per } \\
\text { kWh, including } \\
\text { maintenance and } \\
\text { equipment } \\
\text { replacement }\end{array}$ \\
\hline $\mathrm{Ni}-\mathrm{MH}$ & $\begin{array}{c}\mathbf{\$ 9 4 0 0} \\
\text { Based on } 7.5 \mathrm{~V}, \\
1000 \mathrm{mAh} \text { at } \$ 70 / \text { pack }\end{array}$ & $\begin{array}{c}\mathbf{5 0 0 h} \\
\text { based on } 1 \mathrm{C} \text { discharge }\end{array}$ & $\begin{array}{l}\mathbf{\$ 0 . 1 5} \\
\text { for electricity }\end{array}$ & $\$ 18.50$ \\
\hline Li-ion & $\begin{array}{c}\mathbf{\$ 1 2 0 0 0} \\
\text { Based on } 7.2 \mathrm{~V}, \\
1200 \mathrm{mAh} \text { at } \$ 100 / \text { pack }\end{array}$ & $\begin{array}{c}\mathbf{5 0 0 h} \\
\text {, based on } 1 \mathrm{C} \text { discharge }\end{array}$ & $\begin{array}{l}\mathbf{\$ 0 . 1 5} \\
\text { for electricity }\end{array}$ & $\$ 24.00$ \\
\hline $\begin{array}{c}\text { Rechargeable } \\
\text { Alkaline }\end{array}$ & $\begin{array}{c}\$ 1000 \\
\text { Based on } 7.2 \mathrm{~V} \\
1400 \mathrm{mAh} \text { at } \$ 6 / \text { pack }\end{array}$ & , based on 1C discharge & $\begin{array}{l}\mathbf{\$ 0 . 1 5} \\
\text { for electricity }\end{array}$ & $\$ 95.00$ \\
\hline $\mathrm{Ni}-\mathrm{Cd}$ & $\begin{array}{c}\$ 7000 \\
\text { Based on } 7.2 \mathrm{~V}, \\
1000 \mathrm{mAh} \text { at } \$ 50 / \text { pack }\end{array}$ & $\begin{array}{l}\mathbf{1 5 0 0 h} \\
\text {, based on } 1 \mathrm{C} \text { discharge }\end{array}$ & $\begin{array}{l}\mathbf{\$ 0 . 1 5} \\
\text { for electricity }\end{array}$ & $\$ 7.50$ \\
\hline Fuel Cell & $\$ 3000-7500$ & $2000 h$ & $\$ 0.35$ & $\$ 1.85-4.10$ \\
\hline
\end{tabular}

Another strong point of fuel cells appears when the cost of producing $1 \mathrm{~kW}$ of energy is compared against batteries. As can be observed from Table I the total cost of generating $1 \mathrm{~kW}$ of energy using a fuel cell is up to 5.8 times lower than using existing reusable battery technologies. Also the life span of fuel cells is up to four times longer than popular battery technologies such as Li-ion and Ni-MH. For these reasons fuel cells appear as a very promising candidate for replacing batteries in portable devices in the 
upcoming years. However there still are issues that have to be resolved in order to make fuel cells popular in the market place.

Also, given below in Table II is the table of comparison which shows the advantage of using fuel cells over other backup systems such as engine generator, battery, flywheel and supercapacitor (also known as ultracapacitor) [28].

Table II Comparison of various backup systems

\begin{tabular}{|c|c|c|c|c|c|c||}
\hline $\begin{array}{c}\text { Types of Backup } \\
\text { System }\end{array}$ & $\begin{array}{c}\text { Low } \\
\text { Cost }\end{array}$ & $\begin{array}{c}\text { Low } \\
\text { Maintenance }\end{array}$ & $\begin{array}{c}\text { High } \\
\text { Reliability }\end{array}$ & $\begin{array}{c}\text { Long Run } \\
\text { Time }\end{array}$ & $\begin{array}{c}\text { Low } \\
\text { Pollution }\end{array}$ & $\begin{array}{c}\text { Long } \\
\text { Life }\end{array}$ \\
\hline Engine Generator & No & No & Yes* & Yes & No & Yes \\
\hline VRLA Battery & Yes & No & Yes* & No & No & No** \\
\hline Flywheel & No & Yes & Yes & No & Yes & Yes \\
\hline Ultracapacitor & Yes & Yes & Yes & No & Yes & Yes \\
\hline Fuel Cell*** & Yes & Yes & Yes & Yes & Yes & Yes \\
\hline
\end{tabular}

* Reliability is determined by routine maintenance.

** Assuming valve regulated lead-acid (VRLA) with an average life 5-7 years.

*** Hydrogen-based PEM fuel cell.

\subsection{Hybrid source}

The major disadvantage of fuel cells is that they have long start-up time and slow dynamics. Hence, to overcome these drawbacks, an energy buffer is needed to supply the start-up power and peak load demand. This energy buffer can be either batteries or supercapacitors.

Supercapacitors, also known as ultracapacitors or electrochemical double layer capacitors (EDLC), are electrochemical capacitors that have an unusually high energy density when compared to common capacitors, typically on the order of thousands of times greater than a high-capacity electrolytic capacitor.

Their main attribute is high power capability and long life. Supercapacitors are suited for short-term power backup requirements in the range from seconds to a few 
minutes, while the primary source device provides continuous power for a longer time.

Taking this into consideration the supercapacitor is an ideal device to connect in parallel

with the fuel cell to form a hybrid source capable of satisfying both steady-state and

peak power demand [6]. They are environmentally benign and provide a reliable source

of backup power demanded by a wide variety of applications as shown in Table III.

Table III Short and long term reserve energy sources for backup power

\begin{tabular}{|c|c|c|c|}
\hline Characteristic & Fuel cell with fuel & Supercapacitor & Lead-acid battery \\
\hline Energy storage & $\begin{array}{l}\text { Very good, depends on fuel } \\
\text { available, fuel cells use stored } \\
\text { energy (hydrogen) }\end{array}$ & $\begin{array}{l}\text { Poor, limited to seconds of } \\
\text { use; not a candidate for } \\
\text { energy storage greater than } 1 \\
\text { minute }\end{array}$ & $\begin{array}{l}\text { Good, requires linear } \\
\text { scaling; thus, large } \\
\text { banks for large energy } \\
\text { storage }\end{array}$ \\
\hline $\begin{array}{l}\text { Power delivery } \\
\text { and acceptance/ } \\
\text { power density }\end{array}$ & $\begin{array}{c}\text { Can't accept regenerative } \\
\text { current; provides rated power at } \\
\text { about } 50 \% \text { efficiency }\end{array}$ & $\begin{array}{l}\text { Very good and highly } \\
\text { efficient; can discharge and } \\
\text { accept high current }\end{array}$ & $\begin{array}{c}\text { Reasonable power } \\
\text { delivery; recharging is } \\
\text { slower and must be } \\
\text { managed }\end{array}$ \\
\hline Electrical behavior & $\begin{array}{l}\text { Generates energy } \\
\text { electrochemically }\end{array}$ & $\begin{array}{l}\text { Generates energy by dropping } \\
\text { voltage and ramping current } \\
\text { and is highly predictable }\end{array}$ & $\begin{array}{l}\text { Generates energy at } \\
\text { constant voltage and } \\
\text { variable current }\end{array}$ \\
\hline $\begin{array}{c}\text { Life and } \\
\text { maintenance }\end{array}$ & $\begin{array}{l}\text { Expected life is good and } \\
\text { steadily improving; "hot- } \\
\text { swappable" cartridges can } \\
\text { eliminate downtime }\end{array}$ & $\begin{array}{l}\text { Very good, has many years of } \\
\text { useful life, health monitoring } \\
\text { simple and non-destructive }\end{array}$ & $\begin{array}{l}\text { Limited life requires } \\
\text { destructive health } \\
\text { monitoring and } \\
\text { maintenance over the } \\
\text { life of the application }\end{array}$ \\
\hline $\begin{array}{c}\text { Operating } \\
\text { temperature range }\end{array}$ & $\begin{array}{c}0^{\circ} \text { to } 50^{\circ} \mathrm{C} \text {; limited by cold } \\
\text { weather below } 0^{\circ} \mathrm{C}\end{array}$ & $-40^{\circ} \mathrm{C}$ to $+65^{\circ} \mathrm{C}$ & $-20^{\circ} \mathrm{C}$ to $+55^{\circ} \mathrm{C}$ \\
\hline $\begin{array}{c}\text { Cost-effectiveness } \\
\text { for stationary and } \\
\text { portable power }\end{array}$ & $\begin{array}{l}\text { High value proposition in } \\
\text { applications requiring system } \\
\text { reliability }\end{array}$ & $\begin{array}{l}\text { Cost competitive with } \\
\text { batteries, especially where } \\
\text { portability or reliability is } \\
\text { required }\end{array}$ & $\begin{array}{l}\text { Low initial cost, but has } \\
\text { high maintenance cost } \\
\text { and low reliability for } \\
\text { critical applications }\end{array}$ \\
\hline Footprint & $\begin{array}{l}\text { Highly scalable from small (cell } \\
\text { phones) to mid-sized generation } \\
\text { plants }(250 \mathrm{~kW}) \text {; runtime is a } \\
\text { function of incremental fuel } \\
\text { storage }\end{array}$ & $\begin{array}{l}\text { Highly scalable, lightweight } \\
\text { power; very high power } \\
\text { density; small combined with } \\
\text { fuel cell or other energy } \\
\text { source }\end{array}$ & $\begin{array}{l}\text { Heavy weight and size; } \\
\text { requires one-to-one } \\
\text { scaling for more } \\
\text { runtime; can provide } \\
\text { power and energy }\end{array}$ \\
\hline $\begin{array}{c}\text { Integration } \\
\text { potential }\end{array}$ & $\begin{array}{l}\text { Can be optimized for most } \\
\text { economical design at rated power } \\
\text { with power buffer included }\end{array}$ & $\begin{array}{l}\text { Lasts the life of application so } \\
\text { can be intergraded into the } \\
\text { solution; suitable partner with } \\
\text { energy generator }\end{array}$ & $\begin{array}{l}\text { Requires maintenance } \\
\text { and replacement not } \\
\text { fully integrated into the } \\
\text { solution }\end{array}$ \\
\hline Efficiency & $\begin{array}{l}50 \% \text { fuel-efficient at rated } \\
\text { power; at reduced load, } \\
\text { efficiency varies up to } 100 \%\end{array}$ & $\begin{array}{l}\text { Highly efficient at high loads } \\
\text { charging or discharging-about } \\
95 \%\end{array}$ & $\begin{array}{l}\text { Highly efficient at low } \\
\text { loads-about } 90 \% \text {; low } \\
\text { efficiency at high-rate } \\
\text { charging-about } 50 \%\end{array}$ \\
\hline
\end{tabular}


In order to design the optimum combination and realize the advantages listed above, detailed performance information in the form of a comprehensive electric circuit model is needed for each component. This information is usually unavailable from product data sheets for fuel cells as well as supercapacitors and has to be experimentally determined.

\subsection{Fuel cell based battery-less UPS system}

As discussed earlier, conventional UPS system uses battery as the short energy storage/backup system and engine generators for long term backup to ensure power reliability and continuity for critical loads. There are many disadvantages associated with batteries such as low energy and power density, limited number of charge/discharge cycles, environmentally unfriendly nature and buildup of heat and pressure under heavy energy demands. Also, generators have the disadvantage of high cost and high maintenance requirements. Hence other ways of energy storage and generation have been explored such as flywheels, supercapacitors, fuel cells and their combinations.

For the past few years, fuel cells, especially PEMFC, have been the main focus as the back up power source because of their various advantages over batteries and generators such as longer operating times, higher power capacity, lower maintenance, lower cost and mainly - environmental friendliness. But the major drawbacks of fuel cells are long startup time and slow dynamics. This can be easily overcome by connecting a supercapacitor bank in parallel providing power during the startup of the fuel cell and during peak power demands [7]-[8]. The connection of supercapacitor in parallel with the fuel cell stack has many other advantages on the system as a whole 
which are: $120 \mathrm{~Hz}$ ripple suppression, absorbing/providing peak currents thus smoothening out the glitches in the power to the load (helps in improving the power quality) and finally this hybrid setup helps in improving the fuel economy of the fuel cell.

Hence, based on the above conditions, this thesis looks into the design considerations for a $350 \mathrm{VA} / 200 \mathrm{~W}$, fuel cell powered 1- $\varphi$ offline UPS with one hour of backup power employing modular (fuel cell \& power converter) blocks. The motive is to use a battery based off-the-shelf UPS system and design power converter modules to accommodate for the fuel cell unit and the supercapacitors. Interactions between the internal impedance of the fuel cell and supercapacitor along with their steady state and transient stability are also considered.

\subsection{Previous work}

Over the years many solutions were proposed for solving the problem of power quality disturbances and most of these involve the usage of batteries/generators. As an alternative, the usage of fuel cells and supercapacitor as a hybrid source has been suggested [7]-[9]. The system on the whole is complex and in order to understand their operation better, the equivalent circuits of supercapacitor and fuel cell have been derived.

Many models of fuel cells have been proposed so far [10]-[15], which vary in complexity and accuracy. Using one of these equivalent circuit models the effect of the load current in the performance of the fuel cell has been studied by Choi and Enjeti [16], but their work focused only on the effect of low frequency ripple. 
Various supercapacitor equivalent models [17]-[20] have been developed. In [19], Zubieta and Bonert have shown the voltage dependence of the capacitance. Also, they have explained the development of the equivalent circuit in a clear and simple manner. But this model is obtained by injection of small amounts of current charging the supercapacitor to a particular voltage level and deriving the model parameters at steady state thus, not taking into account the transient analysis. The model suggested in [19] considers the transient behavior of the supercapacitor and this model combined with voltage dependent model in [17] are used. The Nyquist plots, obtained for various charge states using frequency response analyzer, are shifted in both $R_{e}$ and $I_{m}$ directions which implies that at least one capacitance in the model needs to be charge dependent. Also the effects of capacitances increase with the increase in voltage across the supercapacitor terminals have not been analyzed.

The effect on the dynamics of the DC-DC converter due to the internal impedance of the fuel cell has not been studied so far. However analytical tools exist that can facilitate this analysis [21]. The use of a fuel cell as a power source for DC-DC converters can be treated in a similar fashion as when a filter is connected between the power source and a DC-DC converter. An approach to analyze this problem is presented by Erickson and Maksimović in [23] and it is shown that for the case of using a filter the stability and dynamics of the system may be compromised.

Many topologies and designs have been put forward for fuel cell powered UPS system [24]-[28]. Most of these only give the conceptual design and only [27]-[28] have shown the actual implementation of system where the power supplied from the utility is 
transferred to the load via UPS. When the power outage occurs, energy stored in the fuel cell/supercapacitor is used to support the load. As the power outage continues and voltage becomes lower than the pre-determined value, the signal-output unit outputs an operation signal to start the fuel cell system. The fuel cell system begins to warm up and incorporated inverter starts to generate the $110 \mathrm{~V}$ AC power. Power transfer is performed by the synchronization-switch system. However, since this system requires the power conditioning stage for both batteries and fuel cell, the system is expensive. Further, it is disadvantageous in terms of efficiency because the power is always processed by the UPS. Also, another main problem faced is that most backup systems already present have batteries/generators installed. Hence, a system has to be developed which is modular and can be interfaced with the dc link of the existing UPS system.

\subsection{Research objective}

The objective of this thesis is to design and analyze a fuel cell powered batteryless single-phase UPS for small power applications. The suggested system will provide continuous and quality power to critical loads. The proposed topology has a standard module offline UPS system and the battery bank at the dc link is replaced by the proposed hybrid energy source. This hybrid section consists of the fuel cell stack in parallel with a supercapacitor bank and its boost converter.

A good approach to this analysis is start with determination of the impedance model of the fuel cell and supercapacitor. This will be achieved using frequency spectroscopy. The equivalent model will be used to analyze the terminal behavior of the supercapacitor and fuel cell and the interactions between themselves and with respect to 
the power electronic circuits. This will be done both analytically and experimentally and the main focus is on determining static and dynamic stability conditions as well as hydrogen fuel consumption.

Supercapacitor sizing for load transients such as sudden power fluctuations, slow dynamics of fuel preprocessor and overload conditions will be shown. The losses during the charge/discharge cycles of the supercapacitor are estimated and their energy storage capability at different voltage levels will be calculated. For transient stability analysis, the effect of fuel cell internal impedance (extra element) along with the impedance of the supercapacitor (nonlinear) on the transfer function of the DC-DC (boost) converter will be analyzed.

\subsection{Thesis outline}

Chapter I of the thesis presents an overview about the various power quality disturbances and the need for backup energy system and the available backup systems.. The possible solutions for the various disturbances are reviewed and a detailed overview of UPS system is presented. The disadvantages of battery as the backup energy source and alternative backup systems are discussed. This chapter also explains in detail the fuel cell technology and comparison between the various types of fuel cells. Finally, the

proposed topology for fuel cell powered battery-less UPS system and research objectives of this thesis has been presented.

Chapter II discusses the details of modeling the fuel cell, experimental verification of the model and the significance of the proposed model of the fuel cell. Further, the non-linear model of supercapacitor also has been developed on this chapter. 
Chapter III deals with the proposed fuel cell based battery-less UPS topology and an explanation of the block diagram and its components. The specifications of the UPS have been given and the required fuel cell capacity and supercapacitor sizing have been shown. For the specified system, design of the essential converters, namely - buck converter and supercapacitor charging circuit for the supercapacitor bank are discussed. Eventually, the losses in supercapacitor during its charge/discharge cycles have been elaborated. This is followed by mathematical analysis of the interactions between the fuel cell, supercapacitor and the power electronic circuits and their transient and stability analysis.

Chapter IV presents the various experimental results and a comparison of battery based UPS system and the proposed topology has been shown.

Chapter V concludes the thesis by presenting the general conclusion of this work. 


\section{CHAPTER II}

\section{MODELING OF FUEL CELL AND SUPERCAPACITOR}

\subsection{Introduction}

A good starting point to examine the behavior of a system and its transient and steady state stability would be to model its equivalent circuit. Hence, to analyze the proposed UPS system, the modeling of the non-electrical components (fuel cell and supercapacitor) is vital. As the UPS system considered for this thesis uses PEM fuel cell and electrochemical double layer capacitor (supercapacitor), the impedance modeling of a PEMFC and supercapacitor are dealt with in this chapter.

PEMFC devices and supercapacitors have been the focus of significant research over the past few years, targeting a better understanding of the factors that influence their performance, ways to improve their operation and arrive at optimal operating conditions. Many ways for impedance modeling have been looked into and among those, frequency impedance spectroscopy has been the most informative and widely used.

This chapter presents the development of an equivalent impedance model of the fuel cell and supercapacitor using frequency impedance spectroscopy along with some experimental results for the verification of the model.

\subsection{Equivalent circuit of fuel cell}

Several models of PEM fuel cells based on Electrochemical Impedance Spectroscopy have been proposed in the recent years [10]-[17] which vary in complexity and accuracy. Most of these models only give the steady state model of the fuel cell 
stack whereas the analysis of their performance in dynamic conditions is imperative. Also, some of the proposed models are characterized by partial differential equations which make them complex and cause difficulties in identifying the various model parameters. Consequently, a simple but fairly accurate model based on the chemicalphysical knowledge of the phenomena occurring inside the cell has been used [17].

The PEM fuel cell is portrayed by the reactions at the anode and the cathode given by,

$$
\begin{gathered}
\mathrm{H}_{2} \rightarrow 2 \mathrm{H}^{+}+2 e^{-} \\
\mathrm{O}_{2}+4 \mathrm{H}^{+}+4 e^{-} \rightarrow 2 \mathrm{H}_{2} \mathrm{O}
\end{gathered}
$$

A curve of cell voltage variation with respect to the current density is also plotted as shown in Figure 11. The voltage drop seen the figure is due to below mentioned conditions:

1. Limited cathode interfacial dynamics

2. Limited protonic conductivity

3. Anode interfacial kinetics

4. Limited cathode mass transport

5. Cathode flooding 


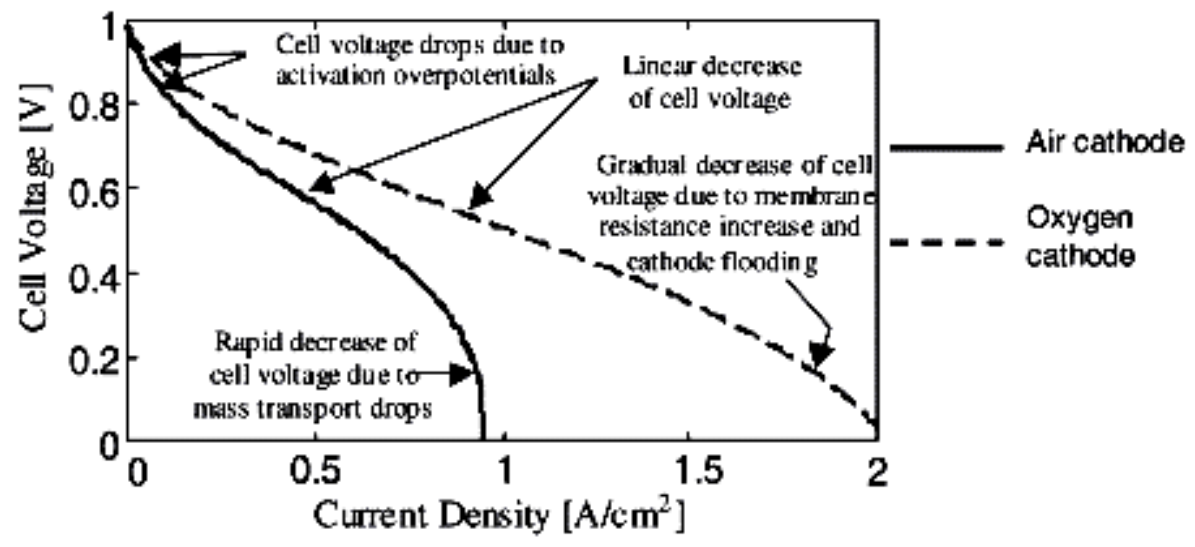

Figure 11. Typical cell voltage vs. current density plots for PEM fuel cells and a common interpretation for volatge drop

Based on many assumptions as given in [15], the cell voltage versus current density diagram, the characteristic chemical reactions and the fuel cell model is derived as shown in Figure 12 [17].

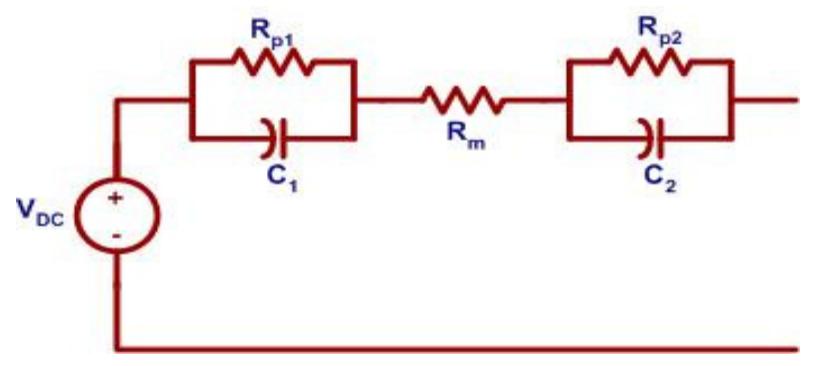

Figure 12. Equivalent circuit for PEM fuel cell

This equivalent circuit consists of the resistance of the membrane $R_{m}$, which is related to the electrolyte resistance. Also the model contains two parallel R-C blocks, $\mathrm{R}_{\mathrm{p} 1}-\mathrm{C}_{1}$ and $\mathrm{R}_{\mathrm{p} 2}-\mathrm{C}_{2}$, which are related to the time constant of each electrode. Specifically these time constants are related to the electron transport phenomena in the anode and cathode. These parameters can be calculated in terms of the fuel cell chemical 
parameters, but this information is rarely available for the power electronics designer. Hence, frequency based impedance spectroscopy is used to determine the parameter values of the given equivalent model. The test setup used is explained below.

The test setup used to obtain the equivalent model of the fuel cell is as shown in Figure 13. The setup consists of Proton Exchange Membrane Fuel Cell Stack (PEMFCS), Programmable Electronic Load (PEL, Chroma 63201), Frequency Response Analyzer (FRA, Venable Model 260), current/voltage probes (Tektronix AM503B Current Amplifier and A6303 Current Probe, Tektronix P5205 Differential Voltage Probe), and a computer with the (Venable) analysis software. The test setup is used to perform both DC and AC tests described in the next sections.

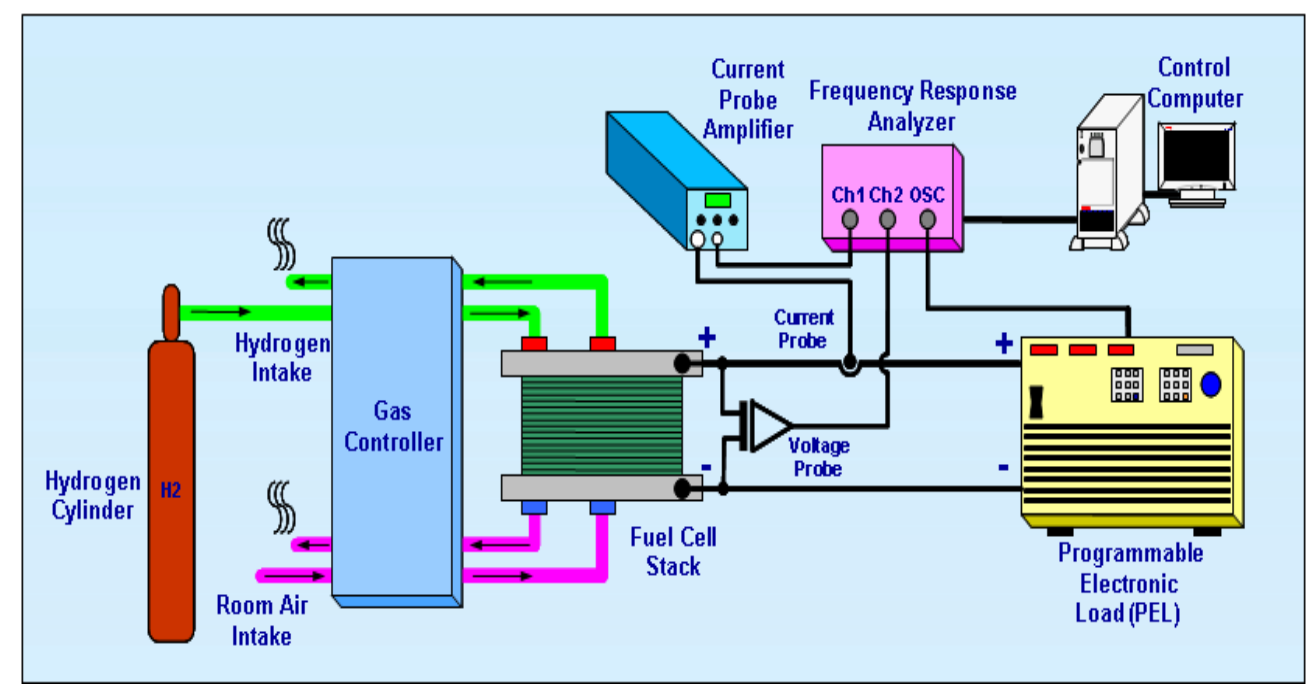

Figure 13. Test setup for measuring the frequency respond of the PEM fuel cell

The test is repeated for a wide frequency range in order to obtain the frequency response of the fuel cell. Figure 14 shows a Nyquist plot of a $300 \mathrm{~W}$ Nexa fuel cell for different load conditions obtained experimentally by using this method. This figure 
shows the resistance and reactance of the fuel cell stack for three different load conditions (light, medium and full) and for frequencies ranging from $0.2 \mathrm{~Hz}$ to $20 \mathrm{kHz}$.

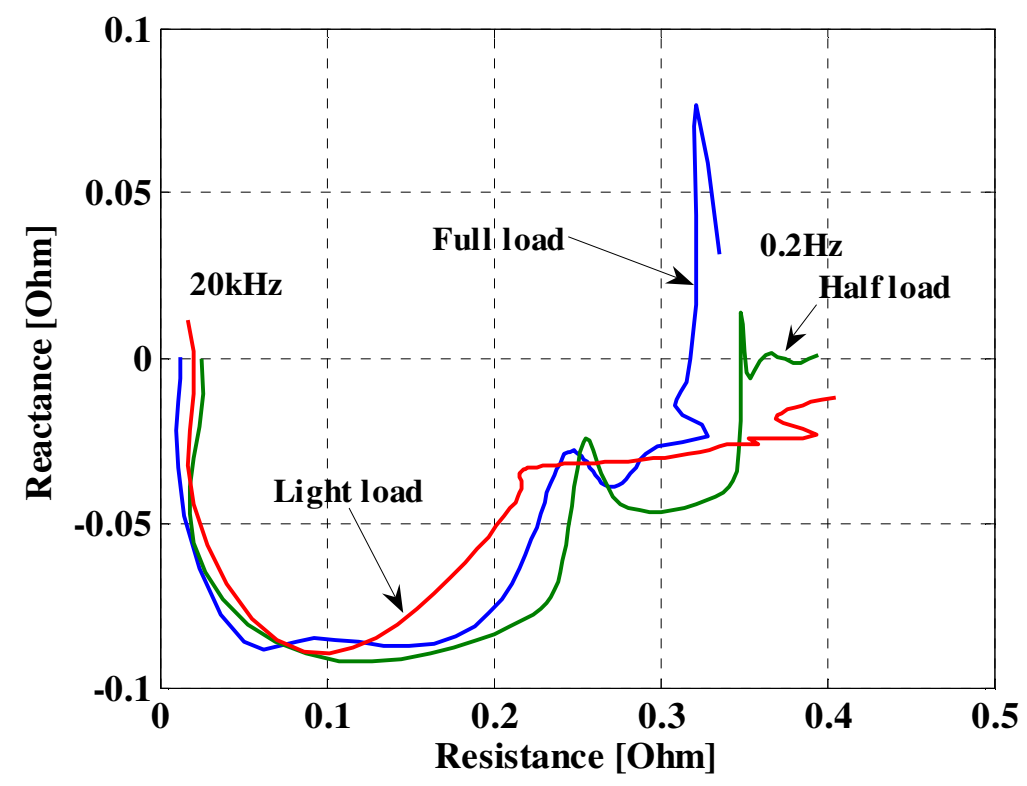

Figure 14. Nyquist plot for $1200 \mathrm{~W}$ fuel cell stack

From this plot it is simple to identify the main elements of the equivalent circuit model and to synthesize the parameters of the circuit model if the chemical data is not known. Each semi circle in the graph corresponds to one R-C time constant and its diameter is proportional to its resistive value while the vertex corresponds to its characteristic frequency. The value of the membrane resistance can be obtained from the graph at the point were the reactance becomes zero. The equivalent circuit parameters of the fuel cell whose response is shown in Figure 14 are listed in Table IV.

It can be observed from Table IV and from the Nyquist plot from Figure 14 that the fuel cell equivalent circuit parameters are a function of the output load. 
Table IV Fuel Cell equivalent circuit parameters

\begin{tabular}{||c|c|c|c|c|c||}
\hline $\begin{array}{c}\text { Load } \\
\text { Condition }\end{array}$ & $\mathbf{R}_{\mathrm{m}}[\mathbf{m} \Omega]$ & $\mathbf{R}_{\mathrm{p} 1}[\mathbf{m} \Omega]$ & $\mathbf{C}_{1}[\mathbf{m F}]$ & $\mathbf{R}_{\mathrm{p} 2}[\mathbf{m} \boldsymbol{\Omega}]$ & $\mathbf{C}_{2}[\mathbf{u F}]$ \\
\hline Light Load & 16.8 & 139.03 & 64.54 & 188.28 & 475.36 \\
\hline Half Load & 16.8 & 111.41 & 95.44 & 229.05 & 376.92 \\
\hline Full Load & 16.8 & 78.65 & 258.96 & 218.75 & 556.85 \\
\hline
\end{tabular}

The resistance values determined using impedance spectroscopy can be easily verified using the V-I (polarization) curve. This curve is obtained by plotting voltage versus current at constant power load as shown in Figure 15. The slope of this curve corresponds to the sum of the resistances of the equivalent model $\left(=R_{m}+R_{p 1}+R_{p 2}\right)$ shown in Figure 12.

\section{Polarization Curve}

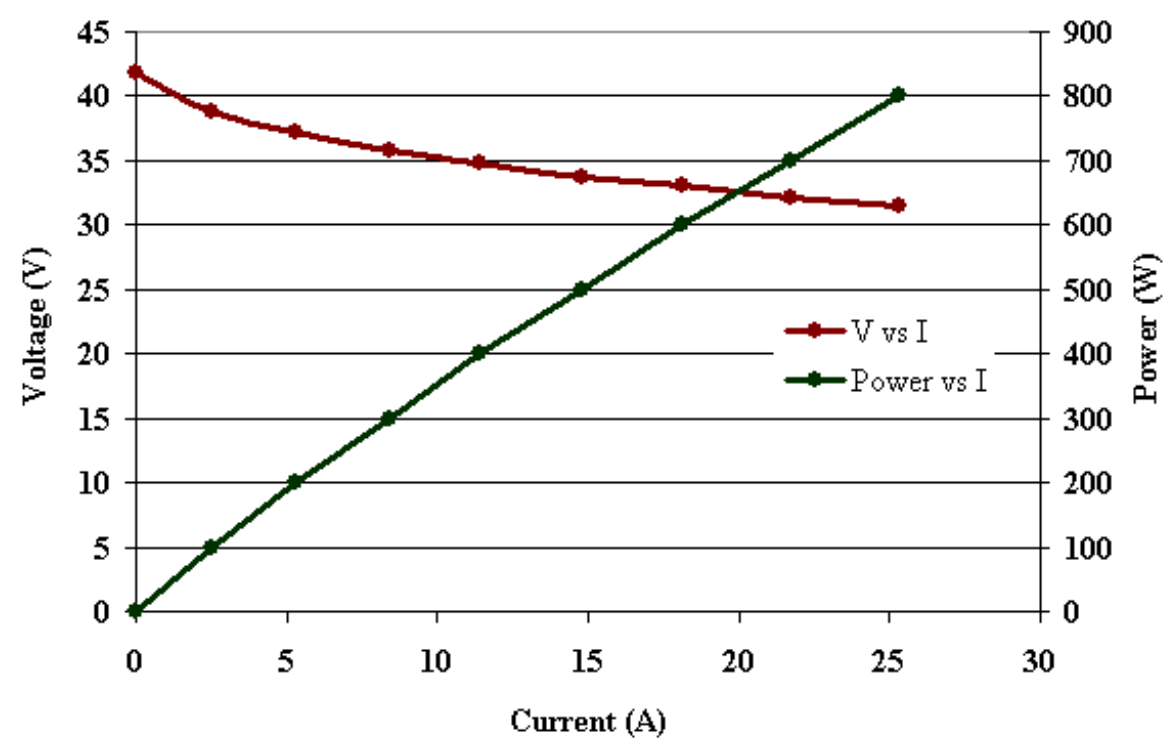

Figure 15. V-I curve for 1200W PEM fuel cell for power up to $200 \mathrm{~W}$ 


\subsection{Non-linear model of supercapacitor}

Supercapacitors, also known as electrochemical double layer capacitors (EDLC), have their capacitance varying non-linearly with the voltage to which they are charged and their operating temperature. The internal impedance of the supercapacitor varies with the surface area of the carbon electrodes, the distance between them and the type of dielectric material and hence has to be modeled accordingly with different time constants and voltage dependent capacitive terms. The modeling of supercapacitor is important as it helps in analyzing the terminal behavior of the supercapacitor with respect to the power electronic circuits. Also, the modeling aids in understanding the interaction between the fuel cell and the supercapacitor bank thus facilitating the stability analysis.

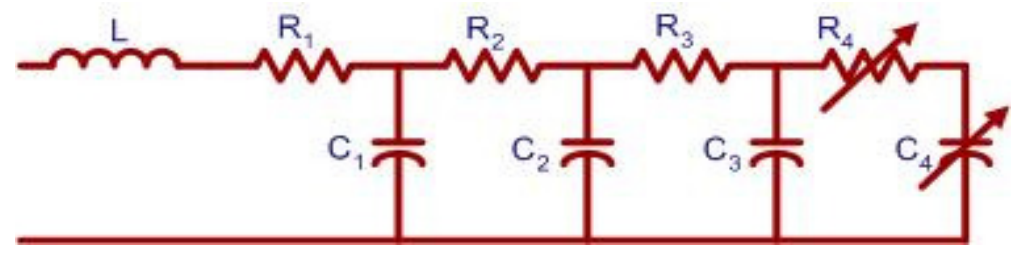

Figure 16. Non-linear model of a supercapacitor

Various models for double layer capacitors have been proposed [18]-[21]. The transmission model (Miller model) shown in Figure 16 has been chosen, in which the moment matching algorithm is used to assign the weights for each capacitor branch. This model accounts for the RC time constants of the electrodes and the leakage resistance present in this model accounts for the discharge in voltage over time. The parameters of 
this model can be determined the same way as the fuel cell by using the impedance spectroscopy.

In impedance spectroscopy, a small ac ripple superimposed with a dc bias voltage. But a difficulty that is faced here is that the capacitance of the supercapacitor under test is so high $(140 \mathrm{~F})$ that the ac ripple has no effect and only parasitic values are reflected. Hence, sixteen supercapacitors are connected in series in order to reduce the capacitance by a factor of nine (to $\approx 8.75 \mathrm{~F}$ ). Also across each supercapacitor, a $10 \mathrm{M} \Omega$ high precision resistor is connected to balance the voltage across the capacitors. The Nyquist plots were obtained only for 0 to $10 \mathrm{~V}$ because of the limitation in dc bias voltage of the frequency spectrometer used. Each of these voltages can be divided by sixteen to obtain the dc bias of each individual supercapacitor. The Nyquist plot for sixteen supercapacitors in series for different voltage levels have been shown in Figure 17.

From Figure 17, it can be observed that the Nyquist plot can be divided as three sections [20]-[21]. The vertical asymptote at low frequencies corresponds to capacitive and equivalent series resistive behavior. At lower frequencies the equivalent series resistance value reaches its maximum (ESR_DC) and includes the resistance of the terminals, electrodes and electrolyte. At the intermediate frequencies, the oblique asymptote is seen and the equivalent series resistance decreases with frequency and reaches a minimum (ESR_HF) at a higher resonant frequency. At frequencies higher than the resonance frequency, the supercapacitor behavior becomes inductive and can be expressed by a resistor ESR_HF in series with a low serial inductor. This behavior is due 
to the very porous nature of the electrodes and the manufacturing process when using wounded technology. It can be seen that the results for ESR_DC and ESR_HF (for 1 $\mathrm{kHz}$ ) in Table $\mathrm{V}$ are in agreement with values found in manufacturer's datasheet [22].

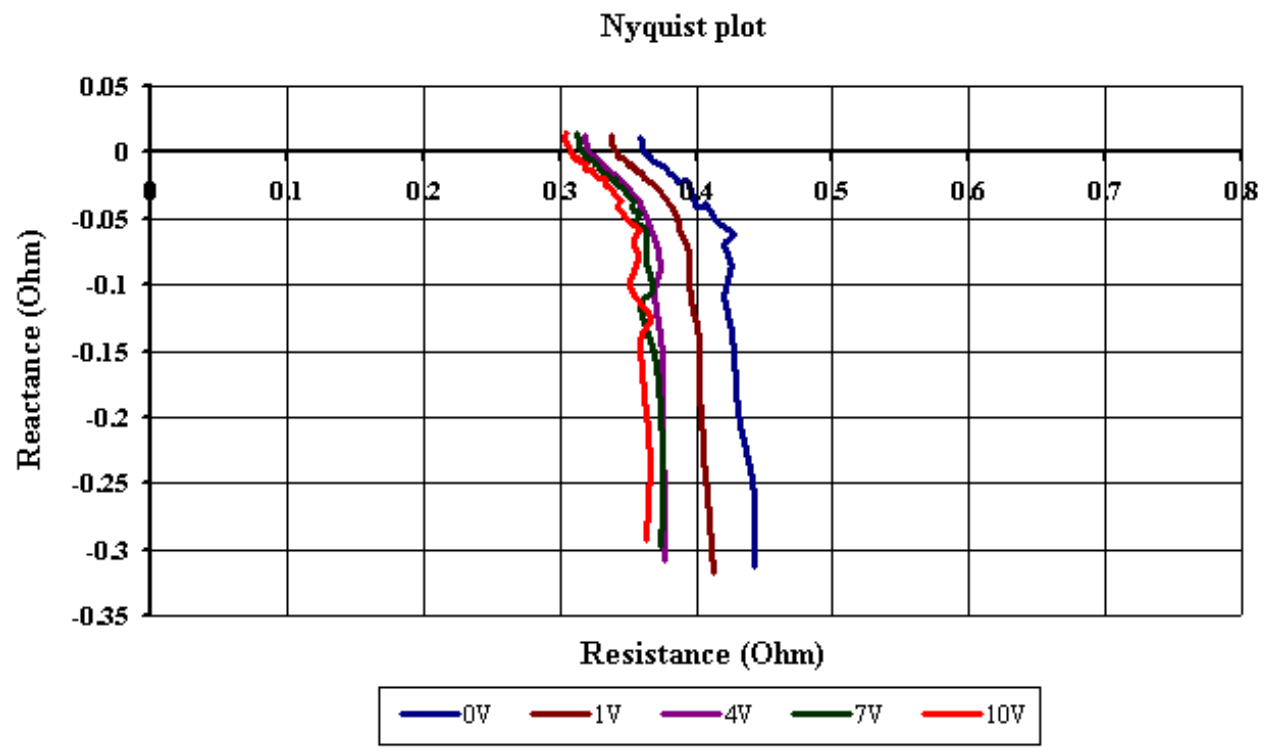

Figure 17. Nyquist plot for sixteen Maxwell BCAP0140 supercapacitor

Looking at the results, the supercapacitor model in Figure 16 and its parameters can be extracted from the Nyquist plots. By construction, the wide electrode-electrolyte interface is obtained by using porous electrodes implying that it is distributed in space. Hence a single capacitor is not enough to model the supercapacitor; distributed resistors and capacitors is required along with a series inductor to account for the nonlinear charge/discharge process [18]-[20]. 
Table V Supercapacitor equivalent circuit parameters

\begin{tabular}{|c|c|c|c|c|c|c|c|c|c|}
\hline $\mathbf{U}$ & $\begin{array}{c}\mathbf{L 1} \\
(\mathbf{u H})\end{array}$ & $\begin{array}{c}\mathbf{R 1} \\
(\mathbf{m O h m})\end{array}$ & $\begin{array}{c}\mathbf{C 1} \\
(\mathbf{m F})\end{array}$ & $\begin{array}{c}\mathbf{R 2} \\
(\mathbf{m O h m})\end{array}$ & $\begin{array}{c}\mathbf{C 2} \\
(\mathbf{F})\end{array}$ & $\begin{array}{c}\mathbf{R 3} \\
(\mathbf{m F})\end{array}$ & $\begin{array}{c}\mathbf{C 3} \\
(\mathbf{F})\end{array}$ & $\begin{array}{c}\mathbf{R 4} \\
(\mathbf{O h m})\end{array}$ & $\begin{array}{c}\mathbf{C 4} \\
(\mathbf{F})\end{array}$ \\
\hline $\mathbf{0}$ & 2.632 & 360.620 & 99.342 & 20.717 & 1.276 & 73.573 & 3.582 & 3.151 & 1.726 \\
\hline $\mathbf{1}$ & 2.679 & 338.750 & 91.184 & 18.313 & 1.253 & 67.931 & 3.592 & 3.873 & 1.206 \\
\hline $\mathbf{2}$ & 2.716 & 327.120 & 70.487 & 14.285 & 0.826 & 38.043 & 2.496 & 0.159 & 1.706 \\
\hline $\mathbf{3}$ & 2.733 & 321.920 & 81.635 & 15.288 & 1.073 & 50.883 & 3.103 & 0.475 & 0.954 \\
\hline $\mathbf{4}$ & 2.743 & 318.970 & 70.751 & 13.863 & 0.760 & 33.303 & 2.174 & 0.111 & 2.127 \\
\hline $\mathbf{5}$ & 2.751 & 316.220 & 72.209 & 13.481 & 0.791 & 37.447 & 2.477 & 0.156 & 1.837 \\
\hline $\mathbf{6}$ & 2.871 & 319.050 & 77.462 & 13.906 & 0.824 & 37.975 & 2.483 & 0.140 & 1.805 \\
\hline $\mathbf{7}$ & 2.880 & 314.400 & 79.911 & 13.064 & 0.773 & 33.940 & 2.192 & 0.102 & 2.289 \\
\hline $\mathbf{8}$ & 2.890 & 311.610 & 84.061 & 12.966 & 0.789 & 33.902 & 2.344 & 0.105 & 2.203 \\
\hline $\mathbf{9}$ & 2.909 & 310.380 & 81.901 & 13.118 & 0.790 & 34.428 & 2.309 & 0.112 & 2.307 \\
\hline $\mathbf{1 0}$ & 2.923 & 305.940 & 85.836 & 13.180 & 0.882 & 37.553 & 2.388 & 0.115 & 2.152 \\
\hline
\end{tabular}

Table V gives the parameters of the equivalent model shown in Figure 16. It can be observed that the R-C values vary with the state of charge i.e. the voltage up to which the supercapacitor is charged. Also, the Nyquist plots show a shift along the $\mathrm{x}$ and the $\mathrm{y}$ axis with change in the dc bias voltage applied. This shift can be attributed to charge dependency of at least one resistor and capacitor.

Table VI Nonlinear variation of supercapacitor equivalent model parameters

\begin{tabular}{|c|c|c|c|c|c|c|c|c|c|}
\hline $\mathbf{U}$ & $\begin{array}{c}\mathbf{L 1} \\
(\mathbf{u H})\end{array}$ & $\begin{array}{c}\mathbf{R} 1 \\
(\mathbf{m O h m})\end{array}$ & $\begin{array}{c}\mathbf{C 1} \\
(\mathbf{m F})\end{array}$ & $\begin{array}{c}\mathbf{R 2} \\
(\mathbf{m O h m})\end{array}$ & $\begin{array}{c}\mathbf{C 2} \\
(\mathbf{F})\end{array}$ & $\begin{array}{c}\mathbf{R 3} \\
(\mathbf{m F})\end{array}$ & $\begin{array}{c}\mathbf{C 3} \\
(\mathbf{F})\end{array}$ & $\begin{array}{c}\mathbf{R 4} \\
(\mathbf{O h m})\end{array}$ & $\begin{array}{c}\mathbf{C 4} \\
(\mathbf{F})\end{array}$ \\
\hline $\mathbf{0}$ & 2.793 & 322.271 & 81.344 & 14.744 & 0.913 & 43.543 & 2.649 & $\mathbf{0 . 4 3 4}$ & $\mathbf{2 . 9 1 0}$ \\
\hline $\mathbf{1}$ & 2.793 & 322.271 & 81.344 & 14.744 & 0.913 & 43.543 & 2.649 & $\mathbf{0 . 3 4 9}$ & $\mathbf{1 . 8 8 6}$ \\
\hline $\mathbf{2}$ & 2.793 & 322.271 & 81.344 & 14.744 & 0.913 & 43.543 & 2.649 & $\mathbf{0 . 2 2 3}$ & $\mathbf{1 . 5 2 7}$ \\
\hline $\mathbf{3}$ & 2.793 & 322.271 & 81.344 & 14.744 & 0.913 & 43.543 & 2.649 & $\mathbf{0 . 1 9 1}$ & $\mathbf{1 . 5 0 6}$ \\
\hline $\mathbf{4}$ & 2.793 & 322.271 & 81.344 & 14.744 & 0.913 & 43.543 & 2.649 & $\mathbf{0 . 1 3 9}$ & $\mathbf{1 . 4 5 1}$ \\
\hline $\mathbf{5}$ & 2.793 & 322.271 & 81.344 & 14.744 & 0.913 & 43.543 & 2.649 & $\mathbf{0 . 1 4 1}$ & $\mathbf{1 . 4 5 1}$ \\
\hline $\mathbf{6}$ & 2.793 & 322.271 & 81.344 & 14.744 & 0.913 & 43.543 & 2.649 & $\mathbf{0 . 1 3 3}$ & $\mathbf{1 . 4 9 7}$ \\
\hline $\mathbf{7}$ & 2.793 & 322.271 & 81.344 & 14.744 & 0.913 & 43.543 & 2.649 & $\mathbf{0 . 0 7 0}$ & $\mathbf{1 . 5 8 5}$ \\
\hline $\mathbf{8}$ & 2.793 & 322.271 & 81.344 & 14.744 & 0.913 & 43.543 & 2.649 & $\mathbf{0 . 0 0 0}$ & $\mathbf{1 . 6 3 4}$ \\
\hline $\mathbf{9}$ & 2.793 & 322.271 & 81.344 & 14.744 & 0.913 & 43.543 & 2.649 & $\mathbf{0 . 0 0 0}$ & $\mathbf{1 . 6 7 7}$ \\
\hline $\mathbf{1 0}$ & 2.793 & 322.271 & 81.344 & 14.744 & 0.913 & 43.543 & 2.649 & $\mathbf{0 . 0 0 0}$ & $\mathbf{1 . 6 7 7}$ \\
\hline
\end{tabular}


This has been shown in Table VI and the graphs below (Figure 18-Figure 19) which tell us how the capacitance and resistance vary with voltage. This is given by the quadratic equations:

$$
\begin{gathered}
R_{4}=-0.0006 U^{3}+0.0127 U^{2}-0.1105 U+0.4305 \\
C_{4}=0.0013 U^{4}-0.0346 U^{3}+0.3171 U^{2}-1.163 U+2.8629
\end{gathered}
$$

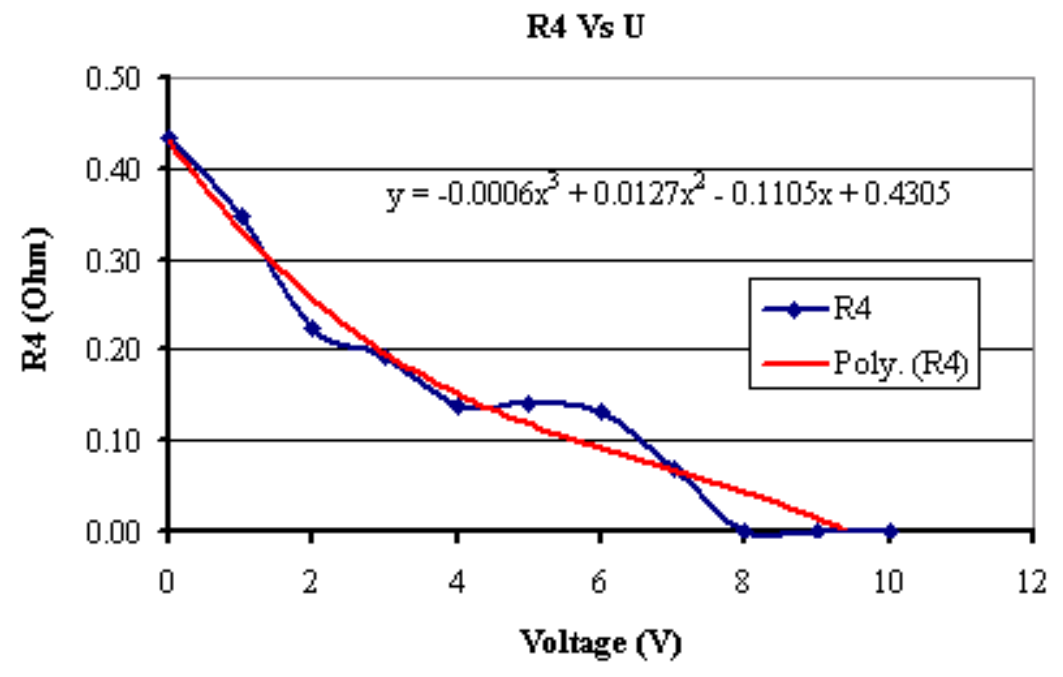

Figure 18. Resistance, $\mathrm{R} 4$ vs. charge voltage

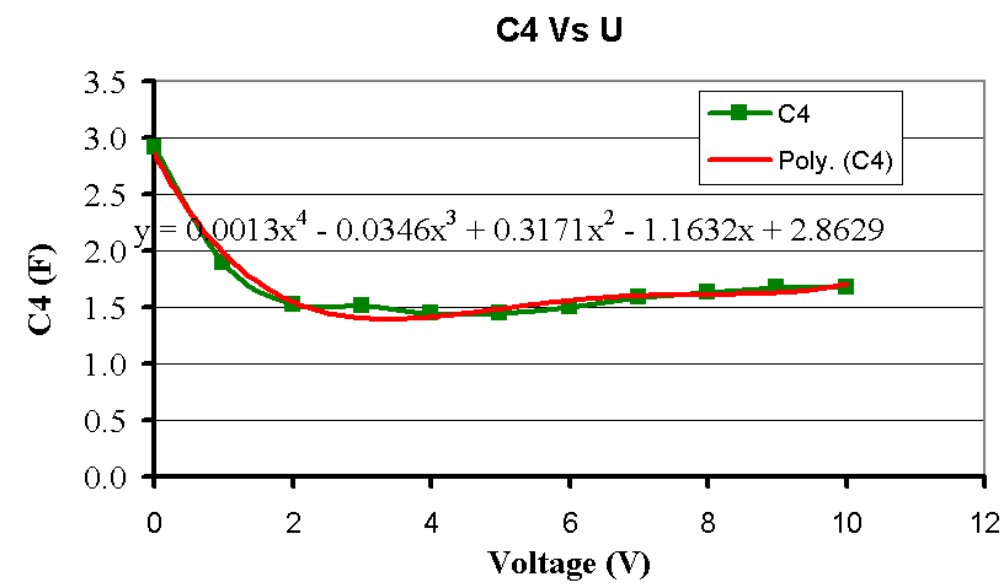

Figure 19. Capacitance, $\mathrm{C} 4$ vs. charge voltage 


\subsection{Conclusions}

In this chapter, the test setup for fuel cell impedance modeling has been explained. Further, the equivalent circuit model for the fuel cell has been derived from the results obtained from the impedance model. Also, the modeling of supercapacitor has bee shown in detail. The Nyquist plots have been plotted from which the proposed equivalent model parameters are extracted. The variation of the supercapacitor capacitance and internal resistance with respect to voltage has been shown. Once the impedance modeling of the supercapacitor bank and fuel cell stack are done, the effect of interfacing them with the power converter circuits and the entire system can be analyzed using the Middlebrook's extra element theorem [23]. This analysis along with the results is shown in the coming chapter. 


\section{CHAPTER III}

\section{PROPOSED FUEL CELL BASED BATTERY-LESS UPS SYSTEM}

\subsection{Introduction}

As previously discussed, conventional UPS system uses battery as the short energy storage/backup system and engine generators for long term backup to ensure power reliability and continuity for critical loads. Due to the obvious disadvantages of generators and batteries, as mentioned earlier, other ways of energy storage and generation have been explored such as flywheels, supercapacitors, fuel cells and their combinations.

For the past few years, fuel cells, especially PEMFC, have been the main focus as the back up power source because of their various advantages over batteries and generators such as longer operating times, higher power capacity, lower maintenance, lower cost and mainly - environmental friendliness. But the major drawbacks of fuel cells are long startup time and slow dynamics. This can be easily overcome by connecting a supercapacitor bank in parallel providing power during the startup of the fuel cell and during peak power demands [7]-[8].

Hence, based on the above conditions, this chapter looks into the design considerations for a 350VA/200W, fuel cell powered 1- $\varphi$ offline UPS with one hour of backup power employing modular (fuel cell \& power converter) blocks as shown in Figure 20. The motive is to use a battery based off-the-shelf UPS system and design power converter modules to accommodate for the fuel cell unit and the supercapacitors. 
Interactions between the internal impedance of the fuel cell and supercapacitor along with their steady state and transient stability are also considered. The supercapacitor sizing, boost converter design and supercapacitor charging circuit has also been elaborated on.

\subsection{Block diagram of the proposed topology}

The block diagram of the proposed fuel cell powered battery less UPS system has been shown in Figure 20. The proposed topology has a standard module online UPS system and instead of the battery bank at the dc link, a fuel cell stack along with a supercapacitor bank, supercapacitor charging circuit and a buck converter (to match the supercapacitor and fuel cell voltage to dc link voltage) are connected as shown.

When the utility power is available, the supercapacitor bank is charged from the ac source through the supercapacitor charging circuit (a flyback converter, explained later in this chapter). When the supercapacitor bank reaches the full state of charge, the charging circuit stops operating and power to the supercapacitor bank is cut off. Meanwhile, power is supplied to the load through the UPS system while the fuel cell supplies for $10 \%$ of the power. This arrangement (continuous operation of fuel cell) is made so that in case of power outage, the startup time is reduced and the supercapacitor bank has to supply power only for the time taken for the fuel cell to ramp up from supplying $10 \%$ load to $100 \%$ load instead of ramping from zero to full load. In case of power outage or other long term disturbances, the fuel cell operates to provide the average output power to the load. Incase of transient and peak power requirements, the 
supercapacitor bank satisfies this peak power demand. Also, the supercapacitor bank can be used to supply power during short term power disturbances.

Normally, the supercapacitor bank satisfies the energy and power requirement but the voltage level might not be appropriate for the dc link of the UPS. Also, there might be some voltage and charge fluctuations in the bank. Hence, a buck converter is added between the supercapacitor bank and the dc link to provide stable dc power.

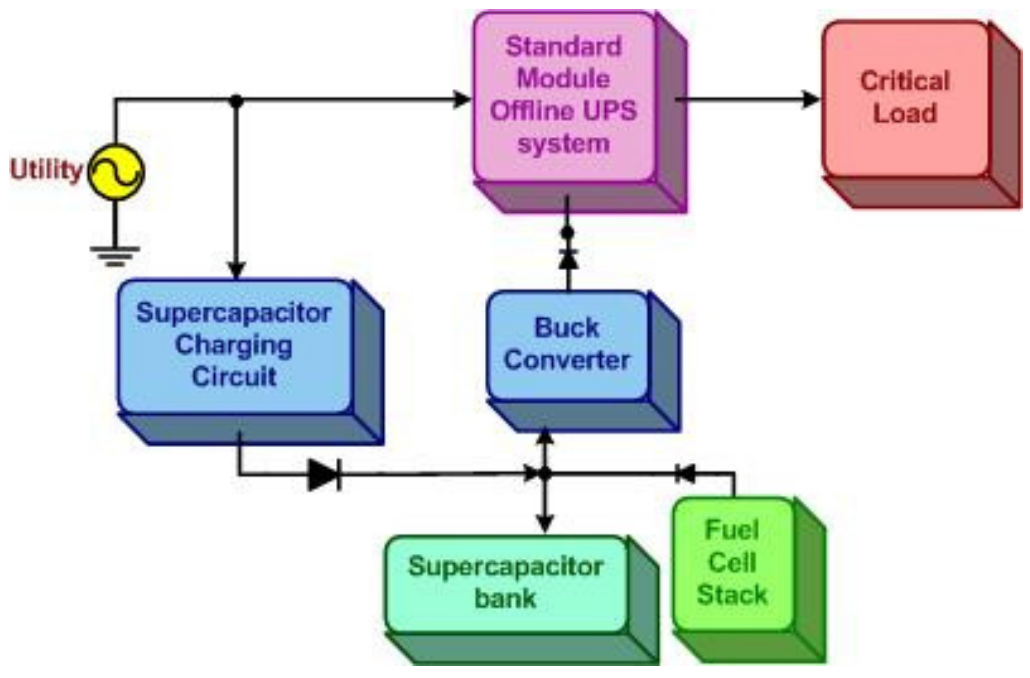

Figure 20. Block diagram of the proposed topology

The main advantage of this topology over battery powered UPS is that it environmentally friendly and produces only green house gases as by-products. Also, they require minimal maintenance because it is not dependent on the floating charge (in case of batteries) or moving parts (in case of engine generators). When the battery discharges, the only way to use it again would be after charging the batteries, but in case of fuel cells, while they are running, the hydrogen cylinders can be switched [29]. Also, the supercapacitor connected in parallel to the fuel cell has various advantages such as: 
$120 \mathrm{~Hz}$ ripple suppression, absorbing/providing peak currents thus smoothening out the glitches in the power to the load (helps in improving the power quality) and finally this hybrid setup helps in improving the fuel economy of the fuel cell.

\subsection{Design example}

\subsubsection{Specification of UPS system}

Table VII shows a typical specification of the proposed fuel cell powered UPS system. The fuel and emission specifications correspond to Nexa fuel cell stack [30] shown in Figure 21. Table VIII shows the specifications of the Nexa fuel cell stack. Performance ratings are largely determined by the power conditioning unit design along with the associated size of the energy storage.

Table VII Specification of proposed fuel cell powered UPS

\begin{tabular}{|c|c|}
\hline \multicolumn{2}{|l|}{ Performances } \\
\hline Power Rating VA/W & $350 \mathrm{VA} / 200 \mathrm{~W}$ \\
\hline Technology & Offline, 1-phase \\
\hline Output Voltage/Frequency & $120 \mathrm{~V} \pm 3 \%, 50 / 60 \mathrm{~Hz} \pm 0.5 \%$ \\
\hline Backup capacity & $200 \mathrm{~W}$ for 17.5 seconds \\
\hline Energy required & $200 \mathrm{~W} * 17.5$ seconds $=3500 \mathrm{~J}$ \\
\hline Overload capacity & $\begin{array}{l}>100 \% \&<=150 \% \text { for } 11.67 \text { seconds } \\
\text { Up to } 200 \% \text { for } 8.75 \text { seconds }\end{array}$ \\
\hline Current Ripple & $120 \mathrm{~Hz}, 24.7 \%$ RMS 35\% peak-peak \\
\hline \multicolumn{2}{|l|}{ Fuel } \\
\hline Composition & $99.99 \%$ dry gaseous hydrogen \\
\hline Consumption Rate & 900 standard liters of hydrogen/kWhr \\
\hline Supply Pressure & 75 PSIG \\
\hline \multicolumn{2}{|l|}{ Emissions (Water and Heat) } \\
\hline Water Exhaust Rate & $750 \mathrm{ml} / \mathrm{kWhr}$ \\
\hline Heat Exhaust Rate & $1.5 \mathrm{~kW} / 1 \mathrm{~kW}$ electricity produced \\
\hline
\end{tabular}


Table VIII Specifications of the Nexa fuel cell stack

\begin{tabular}{|c|c|c|}
\hline Performance : & $\begin{array}{l}\text { Rated net power } \\
\text { Rated current } \\
\text { DC voltage range } \\
\text { Operating lifetime }\end{array}$ & $\begin{array}{l}1200 \text { watts } \\
46 \text { Amps } \\
26 \text { to } 50 \text { Volts } \\
1500 \text { hours } \\
\end{array}$ \\
\hline Fuel : & $\begin{array}{l}\text { Composition } \\
\text { Supply pressure } \\
\text { Consumption }\end{array}$ & $\begin{array}{l}99.99 \% \text { dry gaseous hydrogen } \\
10 \text { to } 250 \text { PSIG } \\
\leq 18.5 \text { SLPM }\end{array}$ \\
\hline $\begin{array}{l}\text { Operating } \\
\text { Environment : }\end{array}$ & $\begin{array}{l}\text { Ambient temperature } \\
\text { Relative humidity } \\
\text { Location }\end{array}$ & $\begin{array}{l}3{ }^{\circ} \mathrm{C} \text { to } 30^{\circ} \mathrm{C}\left(37^{\circ} \mathrm{F} \text { to } 86^{\circ} \mathrm{F}\right) \\
0 \% \text { to } 95 \% \\
\text { Indoors and outdoors }\end{array}$ \\
\hline Physical : & $\begin{array}{l}\text { Length } \mathrm{x} \text { width } \mathrm{x} \text { height } \\
\text { Weight }\end{array}$ & $\begin{array}{l}56 \times 25 \times 33 \mathrm{~cm}(22 \times 10 \times 13 \mathrm{in}) \\
13 \mathrm{~kg}(29 \mathrm{lbs})\end{array}$ \\
\hline Certification : & & CSA, UL \\
\hline Emissions : & $\begin{array}{l}\text { Liquid water } \\
\text { Noise }\end{array}$ & $\begin{array}{l}0.87 \text { liters ( } 30 \text { fluid oz.) maximum per hour2 } \\
\leq 72 \text { dBA @ } 1 \text { meter }\end{array}$ \\
\hline Integration : & $\begin{array}{l}\text { Fuel interface } \\
\text { Electrical interface } \\
\text { Control interface }\end{array}$ & $\begin{array}{l}45^{\circ} \text { flared tube fitting for } 1 / 4 " \text { OD tubing - metallic } \\
\# 8 \text { AWG electrical wire } \\
\text { Full duplex RS } 485\end{array}$ \\
\hline
\end{tabular}

\subsubsection{Fuel cell capacity}

In this section a method to calculate the amount of hydrogen required to supply $0.2 \mathrm{kWh}$ is shown. The [31]-[33] detail an approach from the chemical engineering point of view. However, a more simplistic approach is presented here with some assumptions.

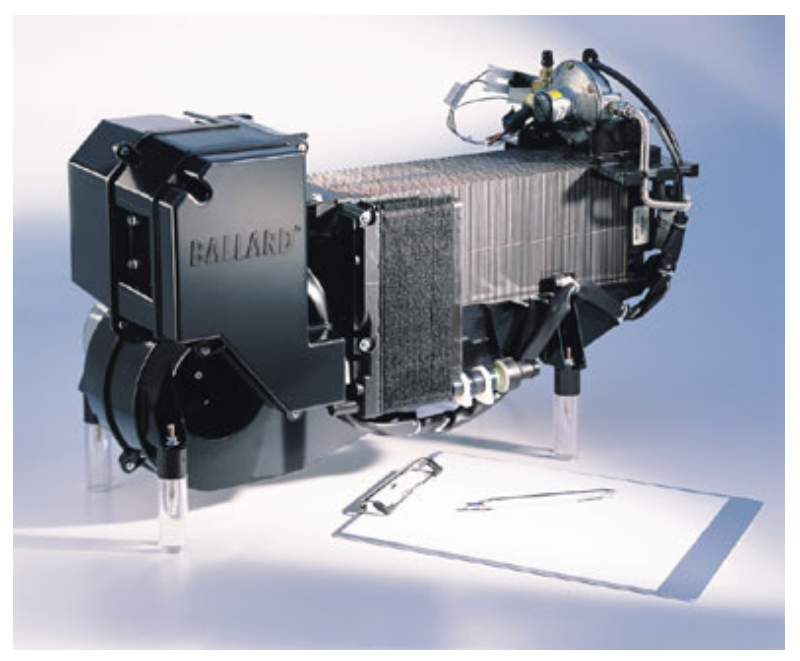

Figure 21. Ballard Nexa 1200W PEM fuel cell 
The required output power $=0.2 \mathrm{~kW}$

The hydrogen density is $\quad=\quad 0.09 \mathrm{~kg} / \mathrm{m}^{3}$

Specific heating value of hydrogen is $=\quad 120 \mathrm{MJ} / \mathrm{kg}$

This is the energy that we can get by burning the hydrogen, which is its theoretical maximum. Only part of this energy can be utilized to produce the electricity via fuel cell due to other losses as explained below. Typical PEM fuel cell efficiency can be calculated as follows:

PEM Fuel cell efficiency

$=\frac{\text { Actual fuel cell output voltage }}{\text { Theoretical output voltage }} *($ Fuel utilization $) *\left(\frac{\text { Net power produced }}{\text { Total power produced }}\right) * 100$

Assuming:

The actual fuel cell voltage $=0.7 \mathrm{~V} /$ per-cell

Theoretical fuel cell voltage $=\quad 1.25 \mathrm{~V} /$ per-cell

Hydrogen fuel utilization $\quad=\quad 95 \%$

(i.e. $5 \%$ of hydrogen fuel is wasted during purging)

$\frac{\text { Net power produced }}{\text { Total power produced }}=0.9$

(i.e. $10 \%$ of the energy is used to power the balancing plant)

PEM Fuel cell efficiency $=\frac{0.7}{1.25} *(0.95) *(0.9) * 100=48 \%$

Since,

$0.2 \mathrm{kWh}=200 \mathrm{Wh}=200 * 3600 \mathrm{Ws}=0.72 \mathrm{MJ}($ mega-joules $)$ 
Weight of the required hydrogen $=$

$\frac{0.72 \mathrm{MJ}}{\text { Specific heating value of hydrogen }} * \frac{1}{\text { PEM Fuel cell efficiency }}$

$$
=\frac{0.72 M J}{(120 M J) *(0.48)}=0.0125 \mathrm{Kg}
$$

Since $0.09 \mathrm{~kg}$ of hydrogen needs 1000 liters,

Now, $0.0125 \mathrm{~kg}$ of hydrogen needs $=1000 * 0.0125 / 0.09=138.88$ liters at 1 bar or 2.899

$\mathrm{lbf} / \mathrm{in}^{2}$

At 150 bar, the volume of hydrogen is: $138.88 / 150=0.925$ liters

Therefore, 0.925 liters of hydrogen fuel at 150 bar is required for powering a $0.2 \mathrm{kWh}$ load.

\subsubsection{Supercapacitor sizing}

The supercapacitor sizing must be such that the energy stored in it is sufficient to supply for the start up power and the peak power demand. The design procedure for supercapacitor sizing is given in [33]. This has been shown below:

Basic system parameters:

Nominal working voltage $=\mathrm{V}_{\mathrm{w}}=40 \mathrm{~V}$

To increase the life of the supercapacitor, the voltage discharge is allowed only till $1 / \sqrt{ } 2$ times the nominal cell voltage,

Maximum voltage $=\mathrm{V}_{\max }=40 \mathrm{~V}$

Minimum voltage $=\mathrm{V}_{\min }=28.28 \mathrm{~V}$

Power to be supplied $=350 \mathrm{VA}$ or $200 \mathrm{~W}$

Time for which the power must be supplied $=t=5 \mathrm{~s}$ 
The change in voltage during the discharge of the capacitor is

$$
\begin{aligned}
d V & =V_{w}-V_{\min } \\
& =40.0-28.28 \\
& =11.72 \mathrm{~V}
\end{aligned}
$$

Hence, the maximum, minimum and average currents (using apparent power rating) are given by,

$$
\begin{aligned}
& i_{\max }=\frac{\text { power }}{V_{\text {min }}}=\frac{350}{28.28}=12.38 \mathrm{~A} \\
& i_{\min }=\frac{\text { power }}{V_{\max }}=\frac{350}{40.0}=8.75 \mathrm{~A} \\
& i_{\text {avg }}=\frac{i_{\text {max }}+i_{\min }}{2}=\frac{12.38+8.75}{2}=10.57 \mathrm{~A}
\end{aligned}
$$

Discharge time $=\mathrm{dt}=5 \mathrm{~s}$

The voltage discharge has two components namely, resistive voltage drop and capacitive voltage drop and this is given by:

$$
d V=i \frac{d t}{C}+i \cdot R
$$

Assuming the RC time constant of the supercapacitor to be 1.1 seconds,

$$
R C=1.1 s
$$

Hence,

$$
R=\frac{1.1}{C}
$$


Substituting this in (8),

$$
\begin{aligned}
d V & =i \frac{d t}{C}+\frac{i}{C} 1.1 \\
C & =\frac{i}{d V}(d t+1.1) \\
& =\frac{10.57}{11.72}(5+1.1) \\
& =5.5 F
\end{aligned}
$$

The capacitance calculated here is the total stack capacitance. As a voltage drop of $1 / \sqrt{2}$ is allowed, the optimum value of capacitance would be $\sqrt{ } 2 * \mathrm{C}$. Assuming that Maxwell BCAP0140 supercapacitor is used whose capacitance is $140 \mathrm{~F}$ and voltage is $2.5 \mathrm{~V}$, the number of capacitors required in parallel

$$
\begin{aligned}
C_{\text {total }} * \sqrt{2} & =C_{\text {cell }} \frac{\# \text { in parallel }}{\# \text { in series }} \\
\# \text { in parallel } & =\frac{5.5 * \sqrt{2}}{140} \times 16 \\
& =0.88 \approx 1
\end{aligned}
$$

Hence the configuration is: one branch with sixteen capacitors in series in each.

The energy stored in the supercapacitor for this configuration is:

$$
\begin{aligned}
E & =\frac{1}{2} C \cdot V^{2}-\frac{1}{2} C \cdot\left(\frac{V}{\sqrt{2}}\right)^{2} \\
& =\frac{1}{4} C \cdot V^{2} \\
& =\frac{1}{4} \cdot\left(140 \frac{1}{16}\right) \cdot(40)^{2} \\
& =3500 \mathrm{~J}
\end{aligned}
$$

During full load, the power supplied for $\frac{3500}{200}=17.5 \mathrm{~s}$ 
For $150 \%$ load power, the time for which power is supplied is $\frac{3500}{1.5 \cdot 200}=11.67 \mathrm{~s}$

For $200 \%$ load power, the time for which power is supplied is $\frac{3500}{2 \cdot 200}=8.75 s$

The amount of capacitance calculated to provide power during overload conditions is sufficient to ensure that the impedance inequalities are met which will be elaborated on in the coming sections. The Table IX shows the detailed specifications for supercapacitor sizing.

Table IX Specification of supercapacitor, BCAP0140 E350 (Maxwell Technologies, 2000)

\begin{tabular}{||l|c||}
\hline Capacitance & 140 Farads $( \pm 20 \%)$ \\
\hline Maximum ESR $\left(\mathbf{2 5}^{\circ} \mathbf{C}\right)$ & $7.2 \mathrm{mOhm}$ \\
\hline Specific Power Density & $3500(\mathrm{~W} / \mathrm{kg})$ \\
\hline Voltage(Cont.) & $2.5 \mathrm{~V}$ \\
\hline Maximum Current & $530 \mathrm{~A}$ \\
\hline Dimensions & $51.0 \times 26.0 \mathrm{~mm}$ \\
\hline Weight & $29 \mathrm{~g}$ \\
\hline Volume & 0.0271 \\
\hline Temperature $(\text { Operating \& Storage })^{\circ}$ & $-40^{\circ} \mathrm{C}$ to $65^{\circ} \mathrm{C}$ \\
\hline Leakage Current $\left(\mathbf{1 2}\right.$ hours, $\left.\mathbf{2 5}^{\circ} \mathbf{C}\right)$ & $0.1 \mathrm{~mA}$ \\
\hline
\end{tabular}

\subsubsection{Design of buck converter}

The output voltage of the fuel cell and supercapacitor bank has variations in the output voltage due to purging of fuel cell and discharge of supercapacitor bank. Hence, the buck converter has to be designed for input range in accordance to the voltage variation of the fuel cell and supercapacitor bank and the output must satisfy the requirements of the dc bus of the UPS module. 
The specifications are as below:

Supercapacitor bank/Fuel cell power output $P_{\text {out }}=200 \mathrm{~W} / 350 \mathrm{VA}$ and the nominal input voltage, $V_{\text {in }}=40-35 \mathrm{~V}$. An output voltage, $V_{o}=12 \mathrm{~V}$ is generated using a simple buck converter as shown in Figure 22. The switching frequency, f, is set at $100 \mathrm{kHz}(\mathrm{T}=$ $1 / 100 \mathrm{k} \mathrm{s})$. The supercapacitor current is calculated for its lowest voltage condition $\left(V_{\text {in }}\right.$ $=28.28 \mathrm{~V})$ as

$$
I_{\text {in }}=\frac{350}{28.28}=12.38 \text { A and } I_{\text {out }}=\frac{350}{12}=29.17 \mathrm{~A}
$$

The duty cycle of the boost converter is, $D=\frac{V_{\text {OUT }}}{V_{I N}}=\frac{12}{28.28}=42.43 \%$

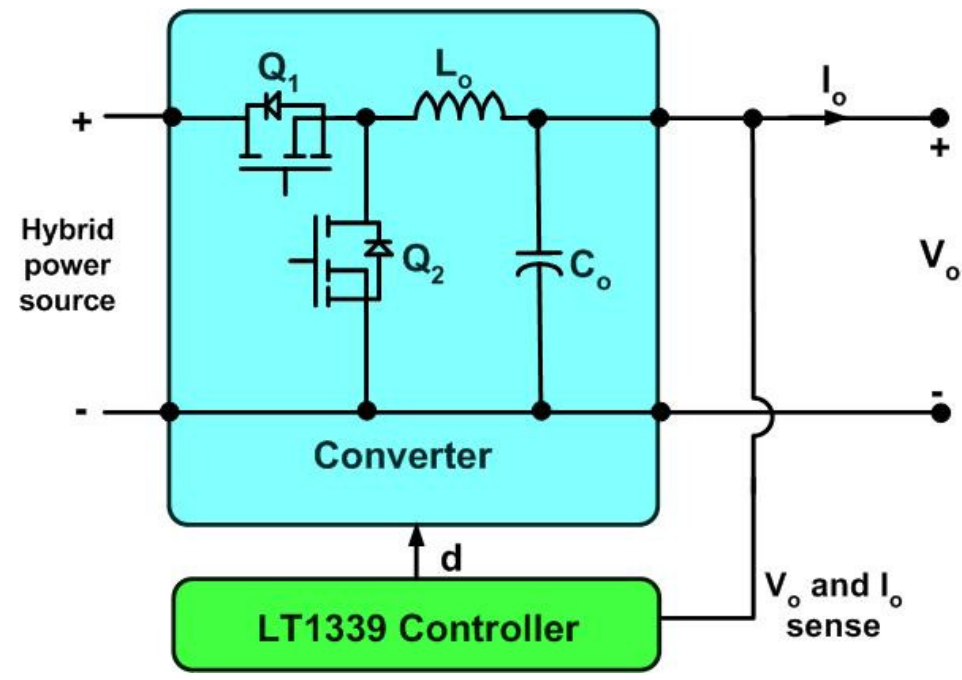

Figure 22. Buck converter

The output filter is designed such that the current ripple is $20 \%$ and voltage ripple is minimal. The inductor calculation is: 


$$
\begin{aligned}
L & =\frac{V_{\text {OUT }}\left(V_{\text {IN }}-V_{\text {OUT }}\right)}{\Delta I \cdot f \cdot V_{I N}} \\
& =\frac{12(28.28-12)}{0.3 \cdot(200 / 12) \cdot 100 k \cdot 28.28} \\
& =13.81 \mu H \approx 18 \mu H
\end{aligned}
$$

The output capacitor is so chosen so that the output voltage ripple is $<1 \%$. Using the formula,

$$
\begin{aligned}
C & =\frac{V_{\text {out }} T D}{2 \Delta V_{\text {out }} R_{\text {load }}} \\
& =\frac{12 \cdot(1 / 100 \mathrm{k}) \cdot 96 \%}{2 \cdot(0.2 \% \cdot 12) \cdot\left(12^{2} / 200\right)} \\
& =3333.33 \mu \mathrm{F}
\end{aligned}
$$

Hence, two electrolytic $2200 \mu \mathrm{F}$ capacitors are used in parallel as output capacitor.

The single controller chip, LT1339 is used. The finer details of design procedure followed are as given in the datasheet of the controller chip [35].

\subsubsection{Design of supercapacitor charging circuit}

The charging of supercapacitors requires certain behavioral considerations [36][37]. As a capacitive element, the ultracapacitor has no charge/discharge memory effects allowing charging and discharging hundreds of thousands of cycles without any effect on the storage capacity. Also with its very low equivalent series resistance (ESR), these components can be charged and discharged at rates far greater than the best of battery technologies. Low ESR and lack of any current limiting mechanism poses a problem for the system integrator - standard battery charging systems usually do not operate well with ultra-capacitors because these components appear as a virtual short circuit to the 
charging system. To solve this problem, a dc power supply that will operate into a short circuit must be selected.

Also, the RC time constant of passive charging networks is usually too long. Therefore, linear regulators are inefficient components for ultracapacitor charging. There are many recommended methods of charging supercapacitors such as constant current charging, constant power charging, and AC line charging.

Here, constant current charging has been chosen as it is the simplest method of active charging of the supercapacitor bank. This has been implemented in two steps simple diode bridge rectifier followed by flyback converter as shown in Figure 23.

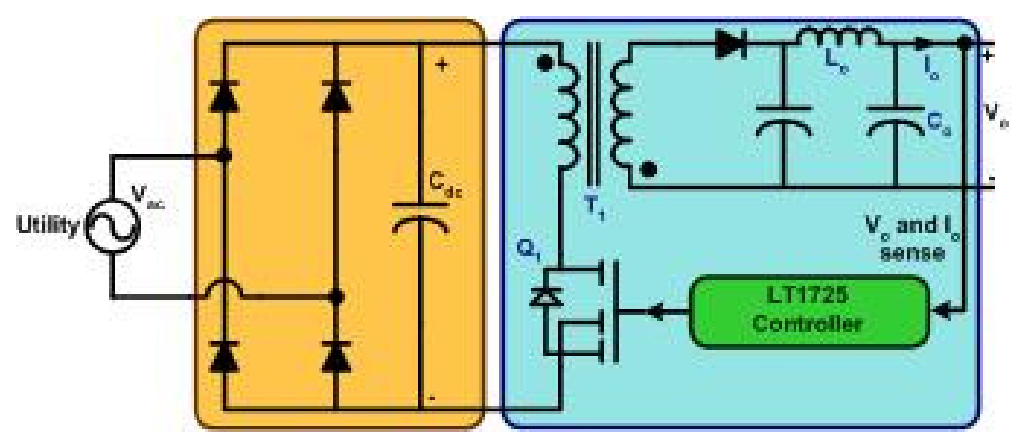

Figure 23. Supercapacitor charging circuit

The diode bridge rectifier has been implemented with the MB88 rectifier. The output filter inductor and capacitor have been chosen as $10 \mu \mathrm{H}$ and $100 \mu \mathrm{F}$ respectively. The input of the rectifier is the ac mains while the output voltage variation is $95-115 \mathrm{~V}$. This is the input for the flyback converter. The flyback converter is controlled using LT1725 controller chip. The design procedure is followed as given in [38]-[39]. The current sensing resistor controls the charging current of the supercapacitor bank and the voltage limit is set to the maximum bank voltage level. 


\subsection{Losses in supercapacitor}

There are significant losses in the supercapacitor during the charge/discharge cycles mainly due to the equivalent series resistance (ESR) of the capacitor. In order to quantify these losses, a constant power discharge cycle as shown in Figure 24 below is considered. The voltage is assumed to discharge from $\mathrm{V}_{\max }$ to $\mathrm{V}_{\min }$ and current rises from $I_{\min }$ to $I_{\max }$ so that a constant power, $P$ is maintained i.e. these satisfy the condition shown below.

$$
P=V_{\min } I_{\max }=V_{\max } I_{\min }
$$

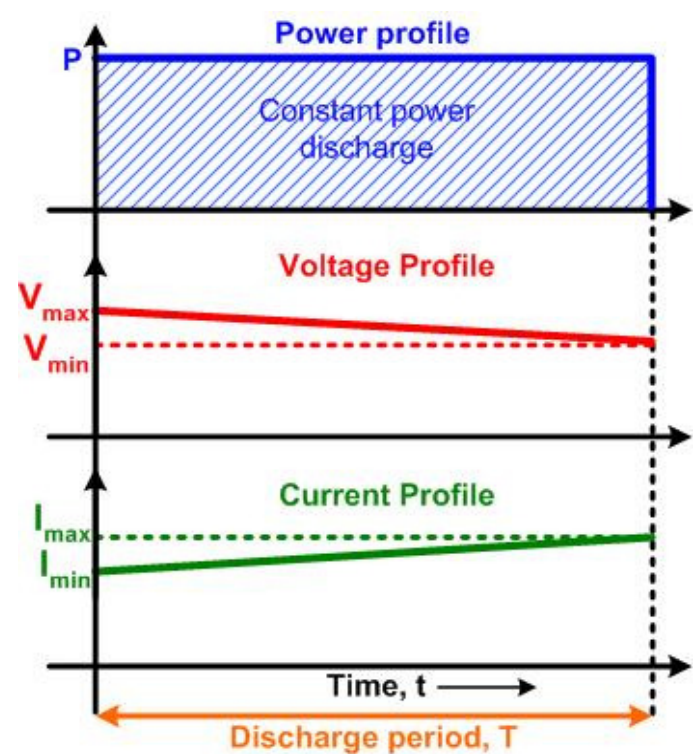

Figure 24. Supercapacitor discharge profile

From the above figure, the current can be expressed as a function of time as shown below: 


$$
\begin{aligned}
\frac{t-T}{0-T} & =\frac{i-I_{\max }}{I_{\min }-I_{\max }} \\
i & =\left(I_{\max }-I_{\min }\right) \frac{t}{T}+I_{\text {min }}
\end{aligned}
$$

The power loss due to ESR is:

$$
P_{\text {loss }}=\frac{1}{T} \int_{0}^{T} i^{2} R d t
$$

Where

$\mathrm{R}$ is the ESR and

$\mathrm{T}$ is the discharge time.

Substituting for i from (9) in (10),

$$
P_{\text {loss }}=\frac{1}{T} \int_{0}^{T}\left[\left(I_{\max }-I_{\min }\right) \frac{t}{T}+I_{\min }\right]^{2} R d t
$$

Therefore, simplifying the above equation, power loss during discharge of a supercapacitor can be calculated as:

$$
P_{l o s s}=\frac{R}{3}\left[I_{\max }^{2}+I_{\max } I_{\min }+I_{\min }^{2}\right]
$$

It can be shown that the above equation holds true for charging cycles also.

\subsection{Steady state stability analysis}

In the given topology the fuel cell connects to a dc link from which an inverter supplies the power required for the load. In this configuration, from the fuel cell terminals point of view, the buck converter can be considered as constant power dc load. This is because regardless of the voltage being produced by the fuel cell stack the output 
voltage of the converter is maintained at a constant voltage. In general for a fuel cell powered system to be stable in steady state, the V-I characteristic of the fuel cell and the constant power locus of the inverter have to intersect at one point, which sets the operating condition of the system. If the two curves do not intersect the source is not able to meet the power demanded by the load.

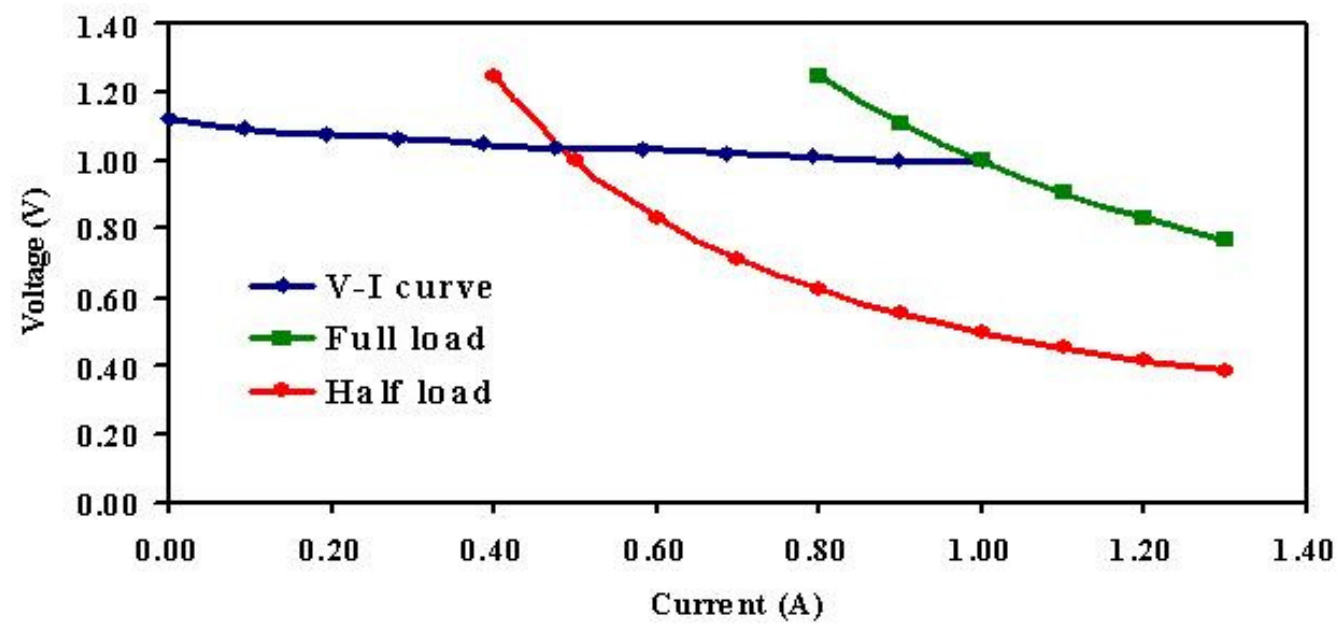

Figure 25. Fuel cell V-I characteristic and load power locus

Figure 25 shows the V-I characteristic of the commercial $1200 \mathrm{~W}$ Nexa fuel cell whose parameters were obtained in the previous chapter (here it is shown only for up to $200 \mathrm{~W}$ as the UPS is rated for $200 \mathrm{~W}$ only). This figure also shows the constant power locus of a $350 \mathrm{~W}$ DC-DC converter operating at full and half load. As can be observed from Figure 25 the constant power locus intersects the V-I characteristic of the fuel cell, and therefore the power requirements of the load are met. However, if the voltage produced by the stack experiences variations due to a reduction in its fuel pressure the curves may not intersect, especially for loads close to full power where voltage 
characteristic of the fuel cell drops quickly as the load current increases. If the curves do not intersect there is a mismatch between the power demanded by the load and the power that the stack can produce. Moreover, if the voltage at the input of the DC-DC converter drops, its controller will increase the input current which results in an additional drop in the fuel cell voltage. In other words, a positive feedback takes place which leads to system instability.

To avoid this problem an energy buffer such as a supercapacitor is required to ride through transient voltage disruptions in the fuel cell output.

\subsection{Transient state stability analysis}

The interaction of the DC-DC converter with the stand-alone fuel cell as well as with the hybrid source has been analyzed in order to investigate dynamic response as well as the stability of the overall system. The power converter controller is generally designed to provide appropriate amount of phase and magnitude margins in order to meet the stability criteria. But once the fuel cell is connected to the input terminals of the power converter, as shown in Figure 26 the output impedance of the fuel cell alters system behavior. 


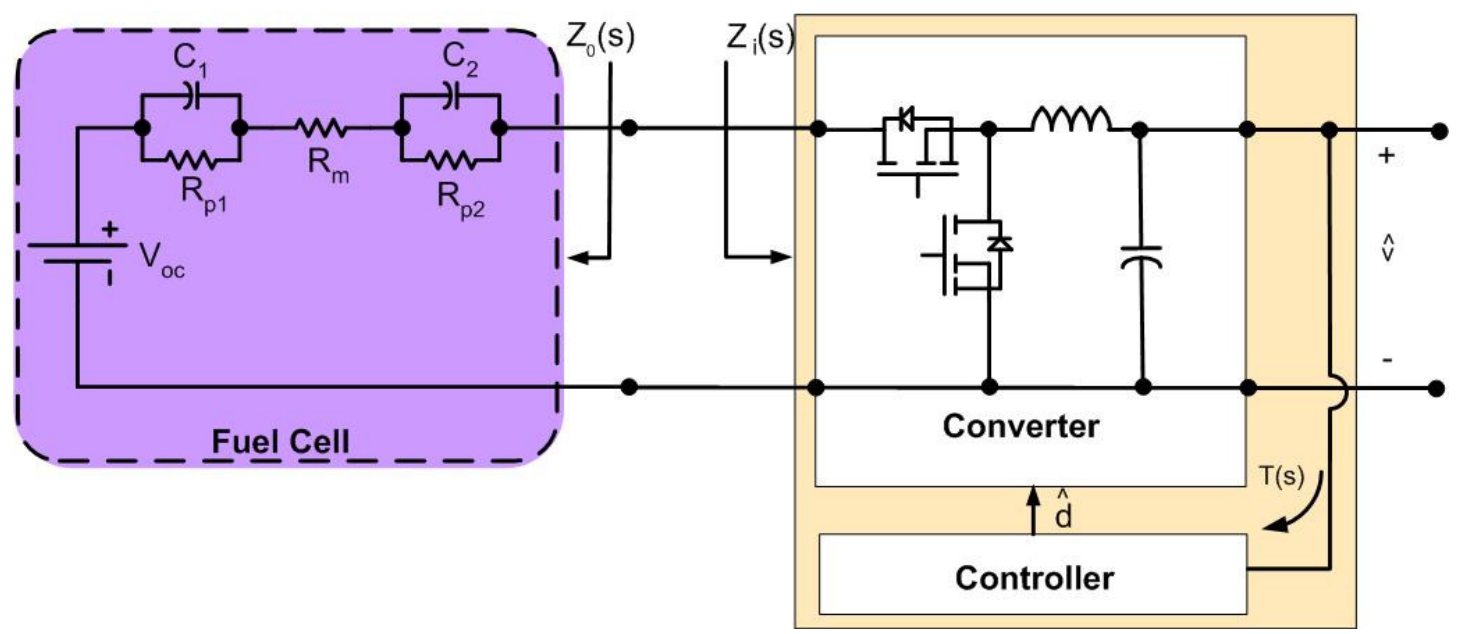

Figure 26. Fuel cell DC-DC converter system

If the internal impedance of the fuel cell stack is considered, Middlebrook's extra element theorem [23] can be used to analyze the effect of the fuel cell onto the dynamics of the converter. Application of this theorem results in the system shown in Figure 27, where the fuel cell output impedance is modeled as an extra element in the system.

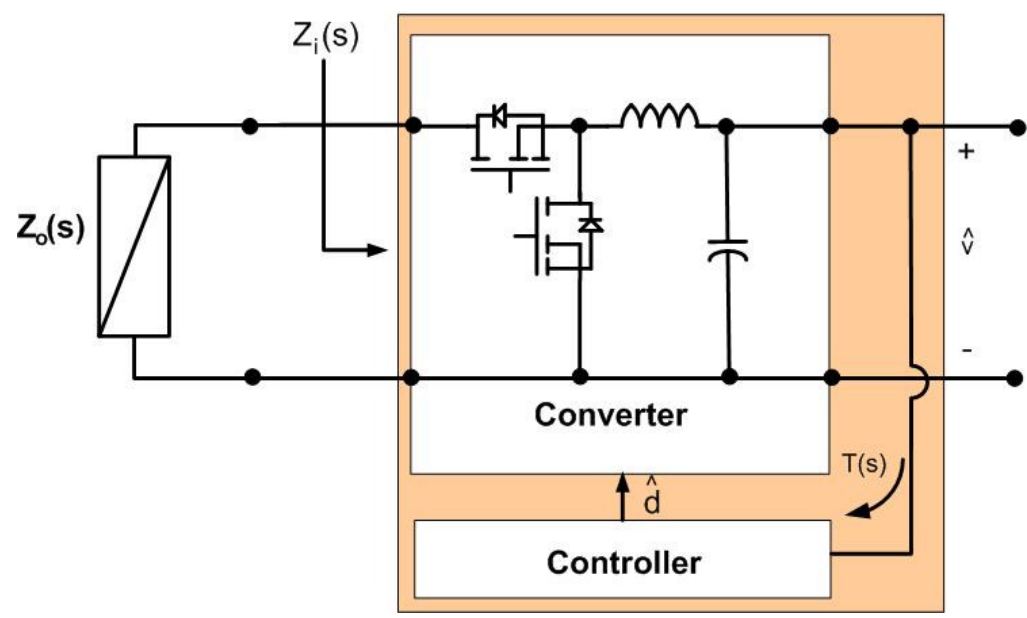

Figure 27. Modeling of fuel cell impedance effect

It can be found that the control to output transfer function of the converter when fuel cell is considered is given by (12). 


$$
G_{v d}(s)=\left(\left.G_{v d}(s)\right|_{Z_{o}=0}\right) \frac{1+\frac{Z_{o}(s)}{Z_{N}(s)}}{1+\frac{Z_{o}(s)}{Z_{D}(s)}}
$$

Where $\left.G_{v d}(s)\right|_{Z_{o}=0}$ is the converter transfer function when the supply is an ideal voltage source, $Z_{N}(s)$ is the input impedance of the converter under the condition that the feedback controller operates ideally, $Z_{D}(s)$ is the input impedance of the converter under the assumption that $\hat{d}(s)=0$, and $Z_{o}(s)$ is the output impedance of the fuel cell. It is obvious that the transfer function of the converter is modified by the output impedance of the fuel cell. Moreover, it can be shown that by connecting the fuel cell to the DC-DC converter all the transfer functions are modified including the control-to-output and the line-to-output, and the converter output impedance. In order to minimize the effect in the dynamics of the converter it has been shown [23] that the following impedance inequalities have to be met.

$$
\begin{aligned}
\left\|Z_{o}\right\| & <<\left\|Z_{N}\right\| \\
\left\|Z_{o}\right\| & <\|\| Z_{D} \|
\end{aligned}
$$

Similarly the converter output impedance of the converter is not affected if

$$
\begin{gathered}
\left\|Z_{o}\right\|<\left\|Z_{e}\right\| \\
\left\|Z_{o}\right\|<\left\|Z_{D}\right\|
\end{gathered}
$$

where $Z_{e}$ is the converter input impedance when its output is shorted. Due to the high output voltage of the fuel cell the converter of choice for this kind of applications is a buck converter. The small signal model for a buck converter is shown in Figure 28a. If 
the fuel cell equivalent circuit model is added to the circuit the small signal equivalent shown in Figure $28 \mathrm{~b}$ is obtained. From Figure $28 \mathrm{~b}$ the converter transfer function when the supply is an ideal voltage source $G_{v d}(s)$, and input impedances of the system, $Z_{N}(s)$ and $Z_{D}(s)$ are given by:

$$
\begin{gathered}
G_{v d}(s)=\frac{D \cdot V_{o}}{1+s \frac{L}{R}+s^{2} L C} \\
Z_{N}(s)=-\frac{R}{D^{2}} \\
Z_{D}(s)=\frac{R}{D^{2}} \frac{1+s \frac{L}{R}+s^{2} L C}{1+s R C}
\end{gathered}
$$

where $V_{o}$ is nominal output voltage, $D$ is the converter duty cycle, $L$ and $C$ are the inductor and capacitor of the converter, and $R$ is a load resistance.

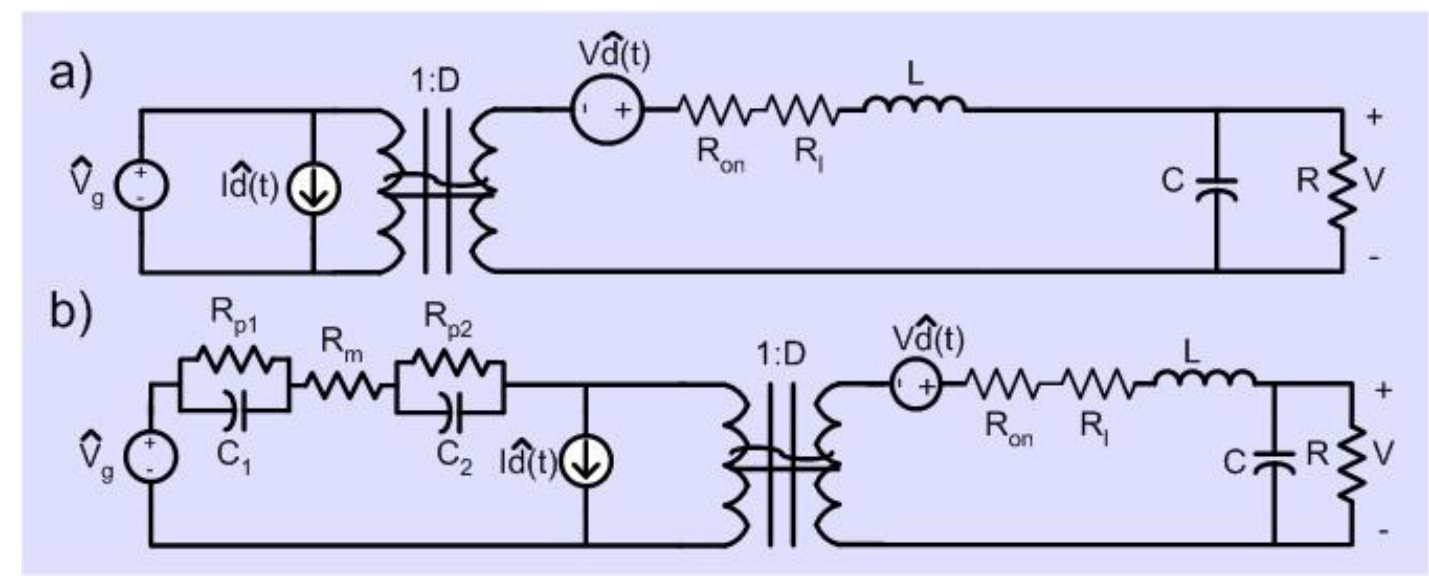

Figure 28. Small signal model of a) buck converter b) when fuel cell is connected

From the fuel cell equivalent circuit discussed in 2.2 its output impedance is given by (20). 


$$
Z_{o}=\frac{s^{2}\left(R_{m} R_{p 1} R_{p 2} C_{1} C_{2}\right)+s\left(R_{m}\left(R_{p 1} C_{1}+R_{p 2} C_{2}\right)+R_{p 1} R_{p 2}\left(C_{1}+C_{2}\right)\right)+R_{m}+R_{p 1}+R_{p 2}}{s^{2}\left(R_{p 1} R_{p 2} C_{1} C_{2}\right)+s\left(R_{p 1} C_{1}+R_{p 2} C_{2}\right)+1}
$$

By plotting the magnitudes of the converter input impedances and fuel cell output impedance (18)-(20) for the fuel cell parameters shown in Table IV and for a $350 \mathrm{~W}$ buck converter designed to operate in continuous conduction with a $20 \mathrm{mH}$ inductance and $4400 \mathrm{mF}$ output capacitance, the graph in Figure 29 is obtained.

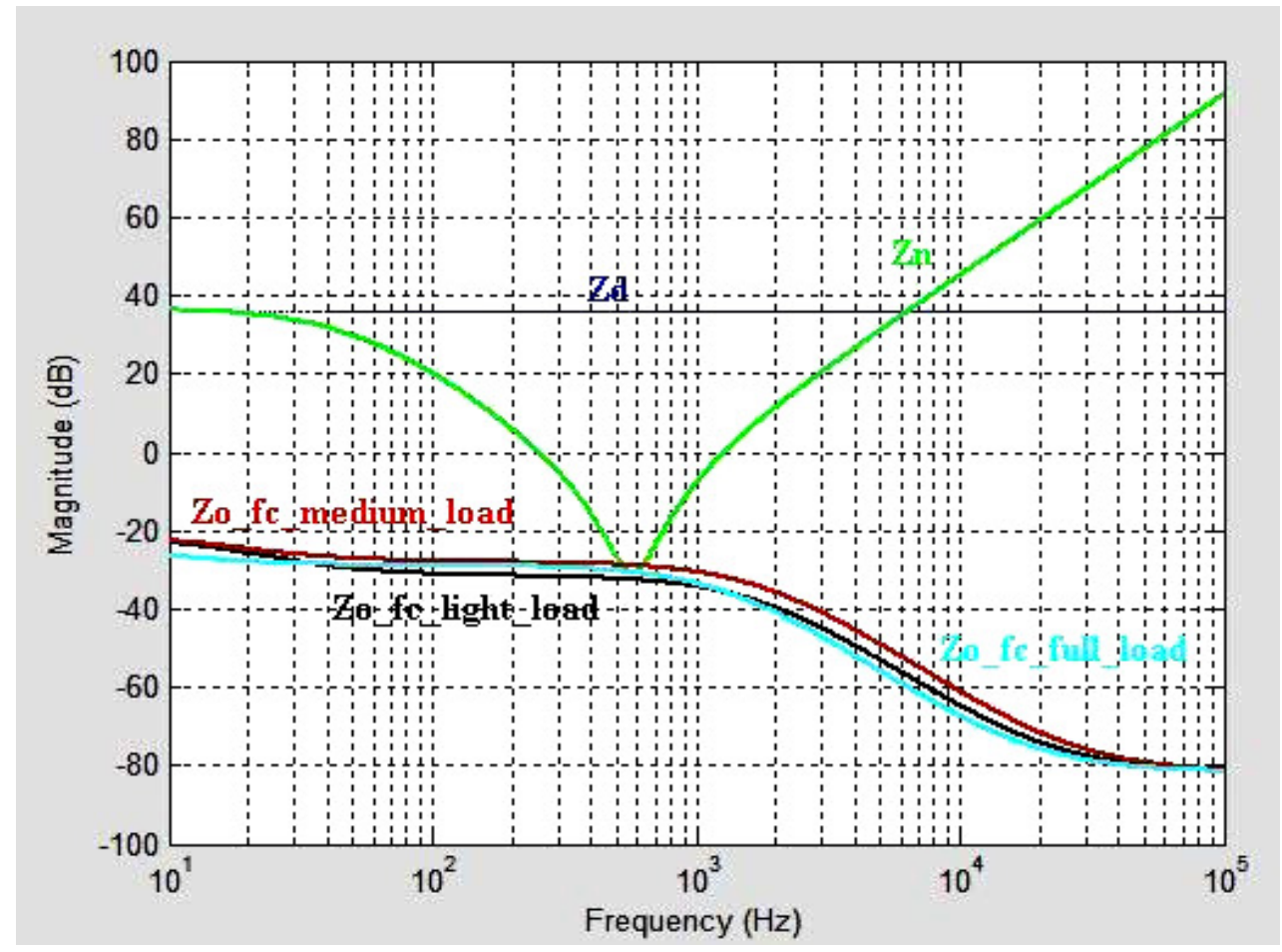

Figure 29. Impedances for fuel cell buck converter system

It can be seen from Figure 29 that the magnitudes of the converter input impedance and the fuel cell output impedance are of comparable magnitudes. From (13) in order to minimize the effect of the fuel cell on the dynamics of the system the impedance inequalities (13)-(14) have to be met. Normally the "much greater than" condition $(>>)$ can be considered to be true if there exist at least $6 \mathrm{~dB}$ of difference 
between the magnitude of the converter and fuel cell impedances. As can be seen from Figure 29 the inequalities may not be satisfied for low frequencies and at the resonant frequency of the buck inductor and output capacitor. Therefore it is important to verify the stability of the system as part of the system designing. At low frequencies the inequalities (13)-(14) are met as long as the DC-DC converter input power is less or equal to the rated power of the fuel cell. On the other hand to meet the design criteria at the resonant frequency of the input impedance of the buck converter either the converter or the fuel cell impedances have to be modified.

A method of modifying the output impedance of the fuel cell is by connecting a supercapacitor in parallel to form a hybrid source. Small signal equivalent model of the portable system powered by hybrid source is formed by combining the equivalent model of the fuel cell and equivalent model of the supercapacitor derived in Section 2.3, and is shown in Figure 30. The effect of the parallel capacitor is displacement of the output impedance of the fuel cell to the left as shown in Figure 31, which increases the distance between the output impedance of the fuel cell and the input impedance of the buck converter. This helps satisfying the impedance inequalities. The modified output impedance of the hybrid source system $Z_{o_{-} H S}$ can be calculated by solving ladder R-C form: 


$$
\begin{gathered}
Z_{o_{-} s c}=s L_{s c}+R_{1}+\frac{1}{s C_{1}+\frac{1}{R_{2}+\frac{1}{s C_{2}+\frac{1}{R_{3}+\frac{1}{s C_{3}+\frac{1}{R_{4}+\frac{1}{s C_{4}}}}}}}} \\
Z_{o_{-} h y b r i d_{-} \text {source }}=Z_{o_{-} s c} / / Z_{o_{-} f c}
\end{gathered}
$$

where $C_{1}-C_{4}, R_{1}-R_{4}$ and $L_{s c}$ are parameters of the supercapacitor and $Z o$ is output impedance of the fuel cell (20).

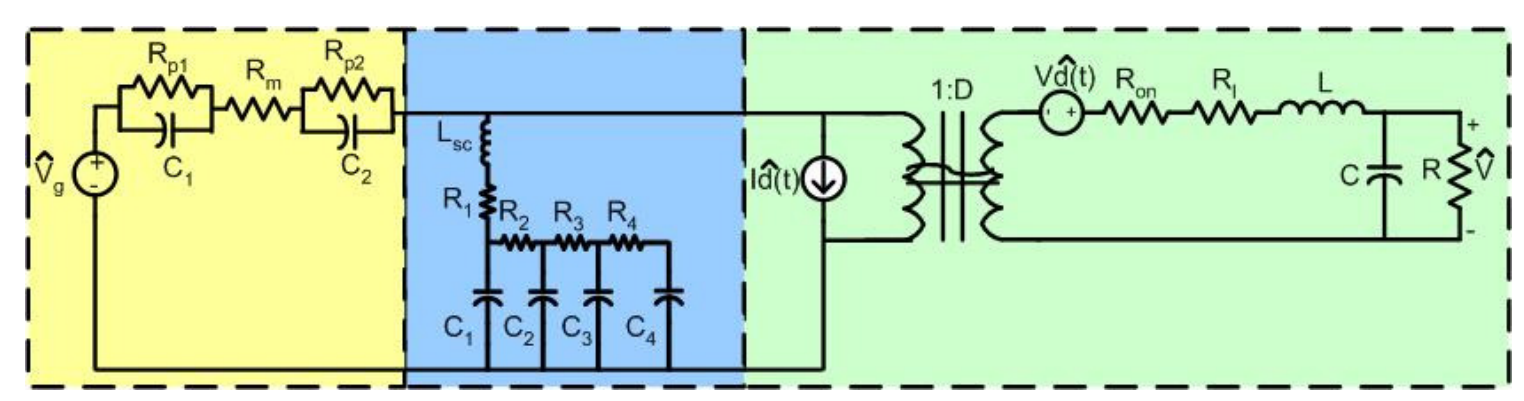

Figure 30. Small signal representation of fuel cell and supercapacitor powered system

Figure 31 shows the fuel cell output impedance for the full load condition (20), and DC-DC input impedance frequency responses for five BCAP0140 supercapacitors connected in series in order to match fuel cell operating voltage range. Supercapacitors charge state is calculated assuming that the nominal fuel cell voltage (full load condition) is divided equally between the supercapacitors, and the parameters are given in Table V. As can be observed from this figure the capacitance needed to modify the output impedance of the fuel cell in order to satisfy (13)-(16) is relatively small. In 
general the amount of capacitance calculated to compensate for the voltage drop during the purging period is sufficient to ensure that the impedance inequalities are met.

\subsection{Conclusions}

This chapter started out with description of the block diagram of the proposed UPS system topology. A design example has been shown which gives the specifications of the proposed UPS system along with detailed specification of the Ballard Nexa fuel cell. A complete design example illustrating the amount of hydrogen storage required for 1 hour power outage and sizing of supercapacitors for transient load demand has been presented for a $200 \mathrm{~W} / 350 \mathrm{VA}$ UPS. A method to size the supercapacitor module was incorporated to overcome the load transients such as instantaneous power fluctuations,

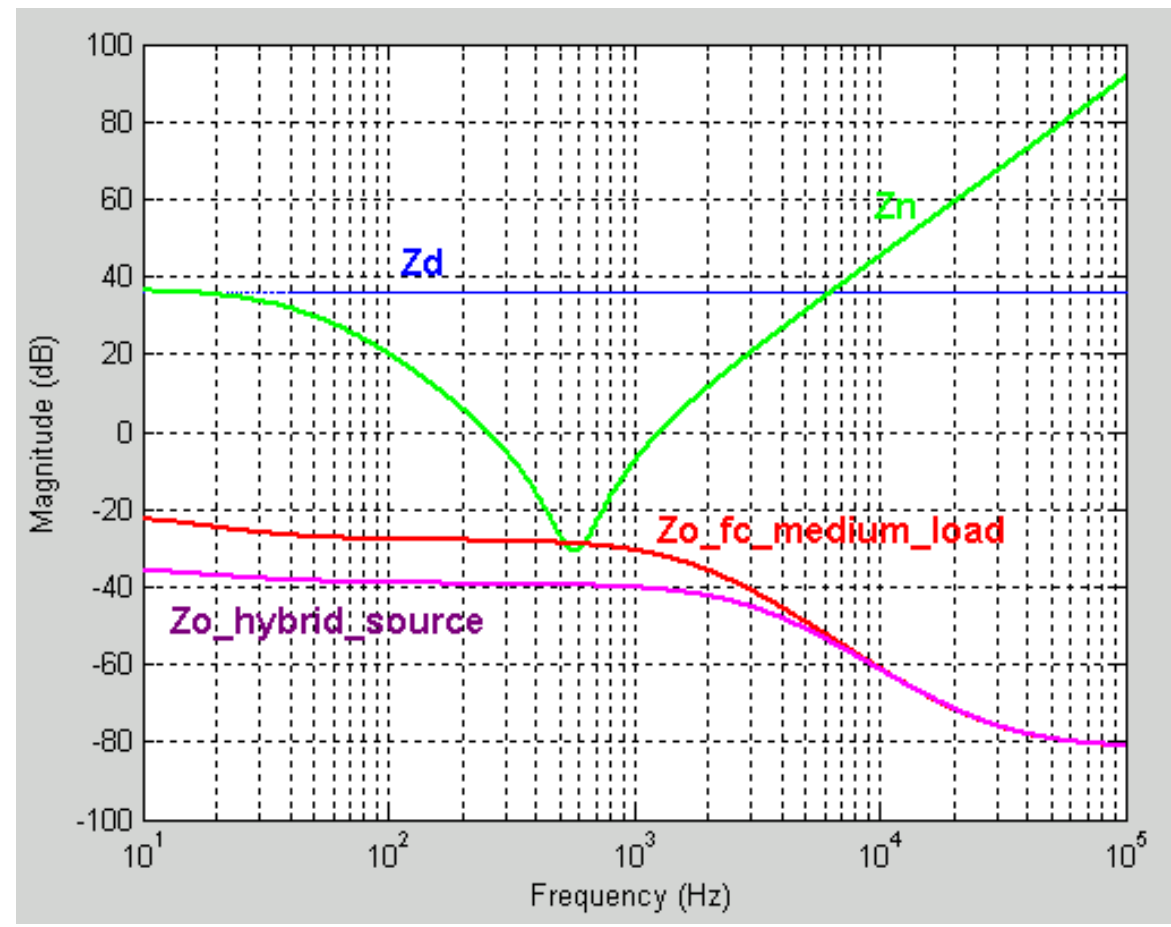

Figure 31. Effect of forming hybrid source 
slow dynamics of the fuel preprocessor and overload conditions. It was shown that the supercapacitor values calculated for overload conditions were sufficient to enhance stability and improve dynamic response of the fuel cell. The design of the buck converter used has been explained hence arriving at the output inductor and capacitor values. In addition, the necessity of the supercapacitor charging circuit and its topology has bee depicted. A mathematical approach to analyze the interactions between the internal impedance of the fuel cell and the dc-dc converter closed loop control to verify steady state and transient stability has been presented. Design inequalities have been reviewed to better understand the interaction between the DC-DC converter and fuel cell and, as well, potential instability conditions. 


\section{CHAPTER IV}

\section{EXPERIMENTAL RESULTS}

\subsection{Introduction}

This chapter compares the various experimental results that were obtained from battery based UPS system and the proposed system. Furthermore, the transient and steady state responses when having just the fuel cell as the power source and while having the hybrid power source (fuel cell and supercapacitor in parallel) have been shown.

\subsection{Experimental results for proposed UPS system}

\subsubsection{Transient response comparison of fuel cell and hybrid power source}

It has been discussed in Section 2.3 that the supercapacitor's capacitance increases as a function of the voltage applied across it and its internal resistance decreases as a function of the voltage. This implies that when the voltage is higher, the energy stored in the supercapacitor is higher than that stored at lesser voltage levels. Also, it implies that the charge/discharge cycles will incur more losses at lower voltage levels than at higher voltage levels. The increased energy storage capacity at higher voltage level is advantageous when connected in parallel with the fuel cell during transient response. This is because, at lighter loads (lesser power demand) the voltage is higher and hence the energy stored in the supercapacitor is higher. When a step load change is applied from lighter load to a higher load, there is more energy available to supply during the step load change. 

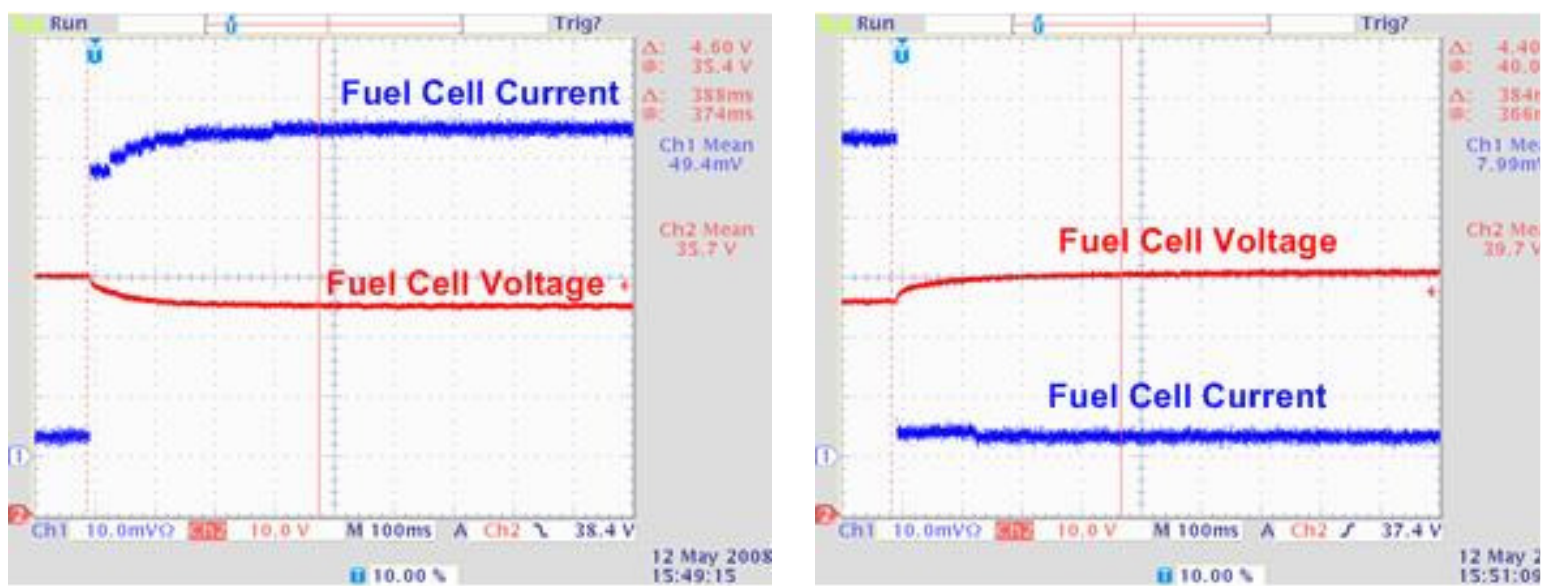

32 a)

32 b)
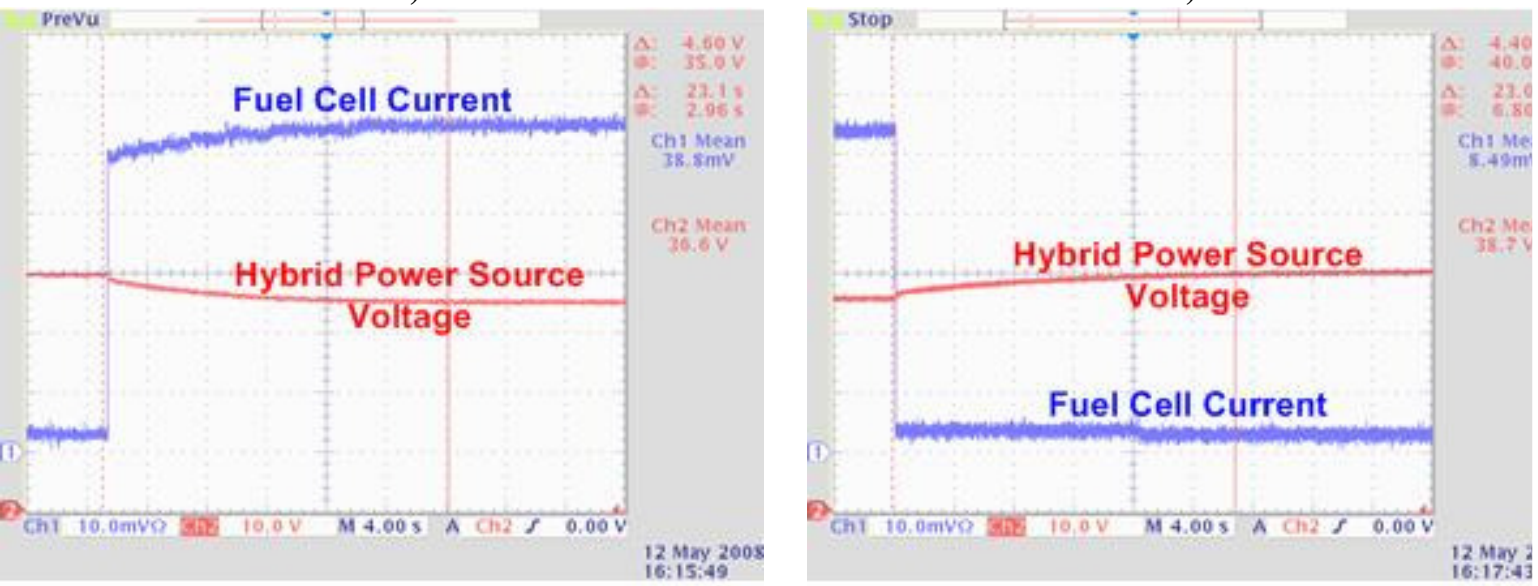

32 c)

32 d)

Figure 32. Transient behavior of fuel cell and hybrid (fuel cell in parallel with supercapacitor) power sources for step change in load between $20 \mathrm{~W}$ and $200 \mathrm{~W}$ a) $20 \mathrm{~W}$ to $200 \mathrm{~W}$ with fuel cell power source; b) $200 \mathrm{~W}$ to $20 \mathrm{~W}$ with hybrid power source; c) $20 \mathrm{~W}$ to $200 \mathrm{~W}$ with hybrid power source; d) $200 \mathrm{~W}$ to $20 \mathrm{~W}$ with hybrid power source

Tests were performed to compare energy storage capability of the supercapacitor at different voltage levels. Hence, step load change between 20W (light load) and 200W (full load) was applied with fuel cell alone as the power source and with hybrid power source (supercapacitor connected in parallel with the fuel cell) and the response times were measured. This gave higher response times for hybrid source when compared to the fuel cell alone as the source. Similar results were seen for step change between $100 \mathrm{~W}$ and $200 \mathrm{~W}$. These results have been shown in Figure 32, Figure 33 and Table X. 

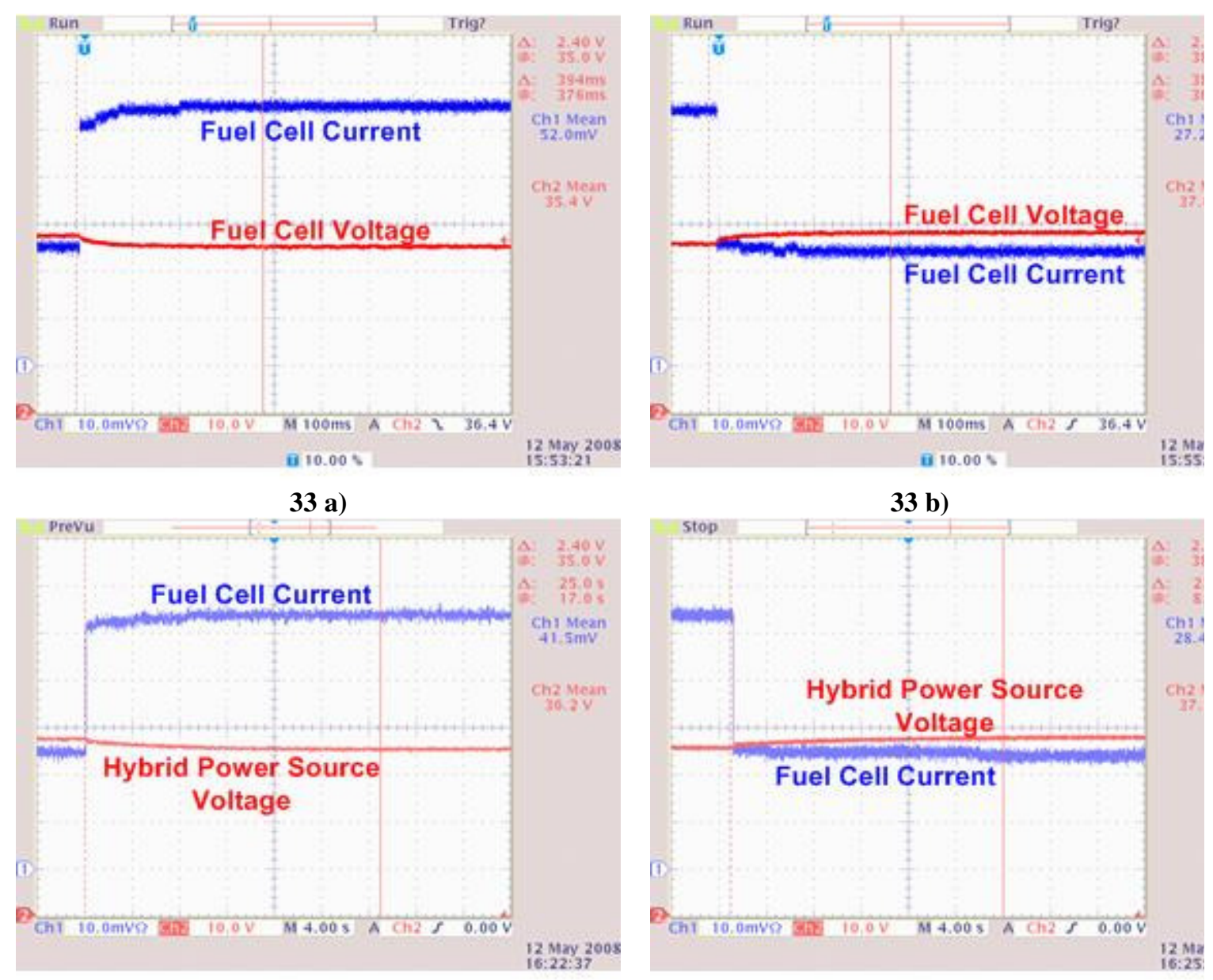

33 c)

33 d)

Figure 33. Transient behavior of fuel cell and hybrid (fuel cell in parallel with supercapacitor) power sources for step change in load between $100 \mathrm{~W}$ and $200 \mathrm{~W}$ a) $100 \mathrm{~W}$ to $200 \mathrm{~W}$ with fuel cell power source; b) $200 \mathrm{~W}$ to $100 \mathrm{~W}$ with hybrid power source; c) $100 \mathrm{~W}$ to $200 \mathrm{~W}$ with hybrid power source; d) $200 \mathrm{~W}$ to $100 \mathrm{~W}$ with hybrid power source

From the result obtained in Section 2.3 , it is seen that the energy stored at $20 \mathrm{~W}$ is 1.198 times higher than that stored at $200 \mathrm{~W}$ while the ratio of energy stored at $100 \mathrm{~W}$ to $200 \mathrm{~W}$ is 1.081 only. Hence, the transition from $100 \mathrm{~W}$ to $200 \mathrm{~W}$ is seen to take a longer time compared to the transition form $20 \mathrm{~W}$ to $200 \mathrm{~W}$. 
Table X Response times for step load changes for fuel cell and hybrid power source

\begin{tabular}{|c|c|c|}
\hline $\begin{array}{c}\text { Power Source } \\
\text { Step change }\end{array}$ & Fuel cell alone as power source & Hybrid power source \\
\hline $20 \mathrm{~W}$ to $200 \mathrm{~W}$ & $388 \mathrm{~ms}$ & $2023.1 \mathrm{~s}$ \\
\hline $200 \mathrm{~W}$ to $20 \mathrm{~W}$ & $384 m s$ & $23 s$ \\
\hline $100 \mathrm{~W}$ to $200 \mathrm{~W}$ & $394 \mathrm{~ms}$ & $25 \mathrm{~s}$ \\
\hline $200 \mathrm{~W}$ to $100 \mathrm{~W}$ & $384 m s$ & $23 s$ \\
\hline
\end{tabular}

\subsubsection{Fuel consumption}

The Ballard Nexa Fuel Cell is monitored using the Nexamon software which monitors various parameters of the fuel cell such as it stack power, current and voltage, fuel cell temperature, air pressure, air flow, fuel consumption etc. The fuel consumption data was collected from this software to compare the fuel consumed when stand alone fuel cell is used power source and when hybrid power source is used. From the results (Figure 34), it can be seen that hybrid source utilizes lesser fuel as against fuel cell power source. The test was performed only for 10 minutes and hence the fuel saved was only around 0.2 liters. It is expected that when the UPS is run for one hour, more than 5 liters of fuel can be saved. Figure 34 shows fuel consumption data for half load (100 W) and full load $(200 \mathrm{~W})$.

\subsubsection{Temperature rise}

The UPS system was run with only the fuel cell as the source as well with the hybrid source. Temperature rise for both the cases were compared for half load (100 W) and full load $(200 \mathrm{~W})$ conditions. It was noticed that there was slightly smaller 


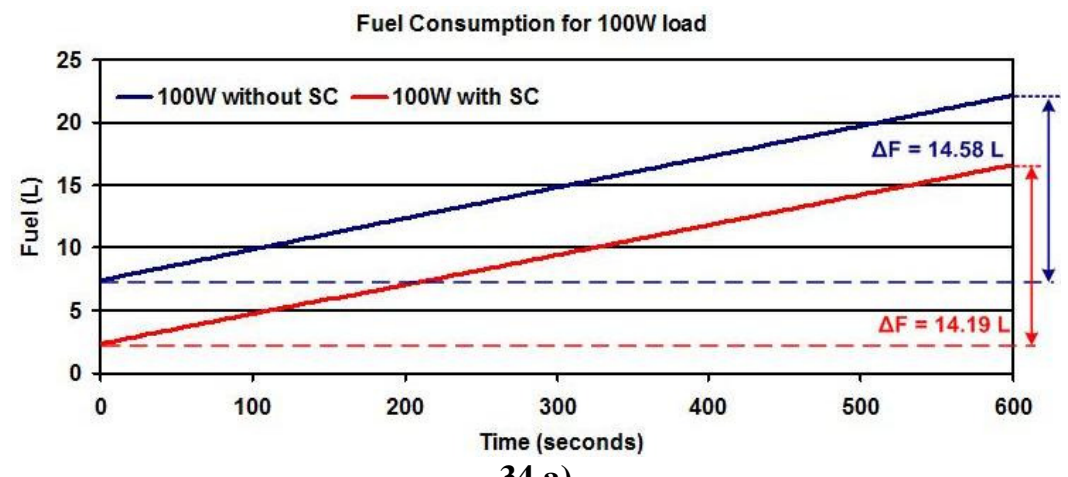

34 a)

Fuel Consumption for 200W load

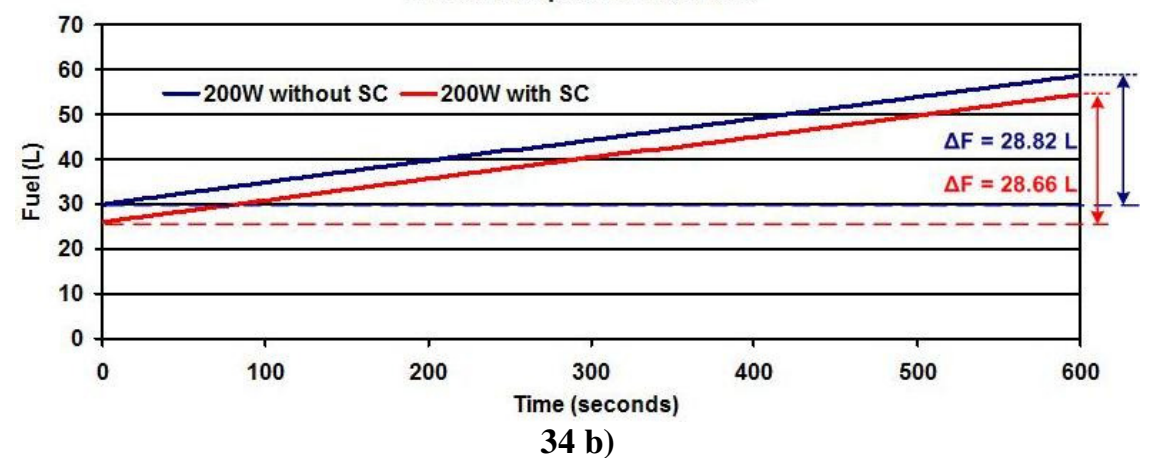

34 b)

Figure 34. Fuel consumption of a) $100 \mathrm{~W}$ load and b) $200 \mathrm{~W}$ load

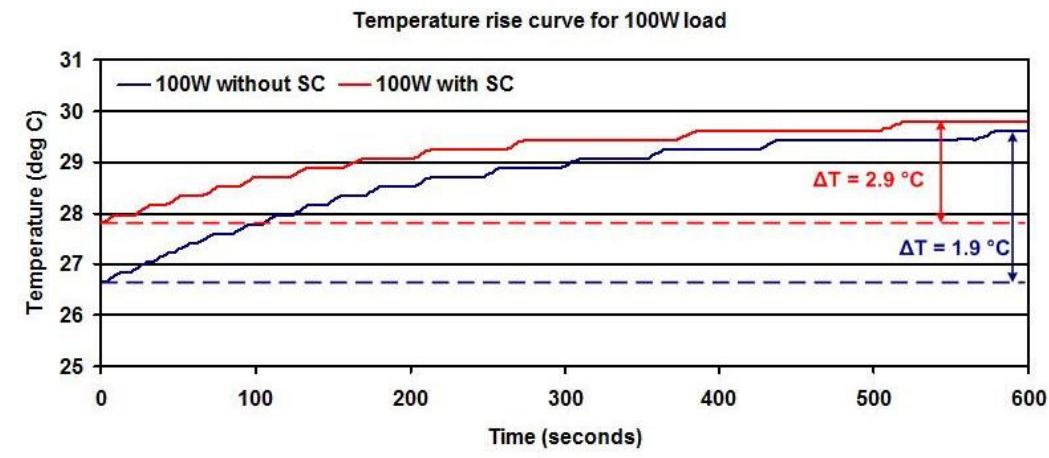

35 a)

Temperature rise curve for $200 \mathrm{~W}$ load

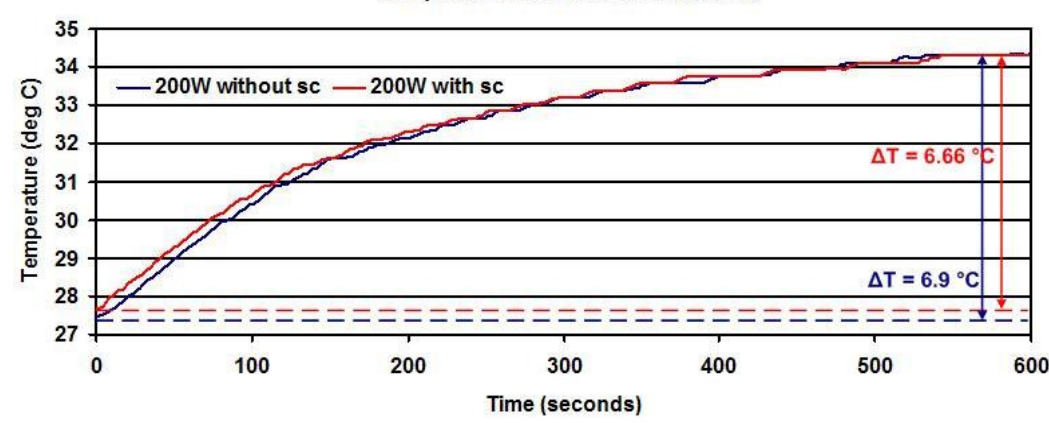

35 b)

Figure 35. Temperature rise curve for a) $100 \mathrm{~W}$ load and b) $200 \mathrm{~W}$ load 
temperature rise when the hybrid power source was used. This test was done only for 10 minutes and has been shown in Figure 35. It is expected that even when the prolonged for few hours, the difference in temperature rise will not be much.

\subsubsection{Performance of battery based and the proposed UPS systems}
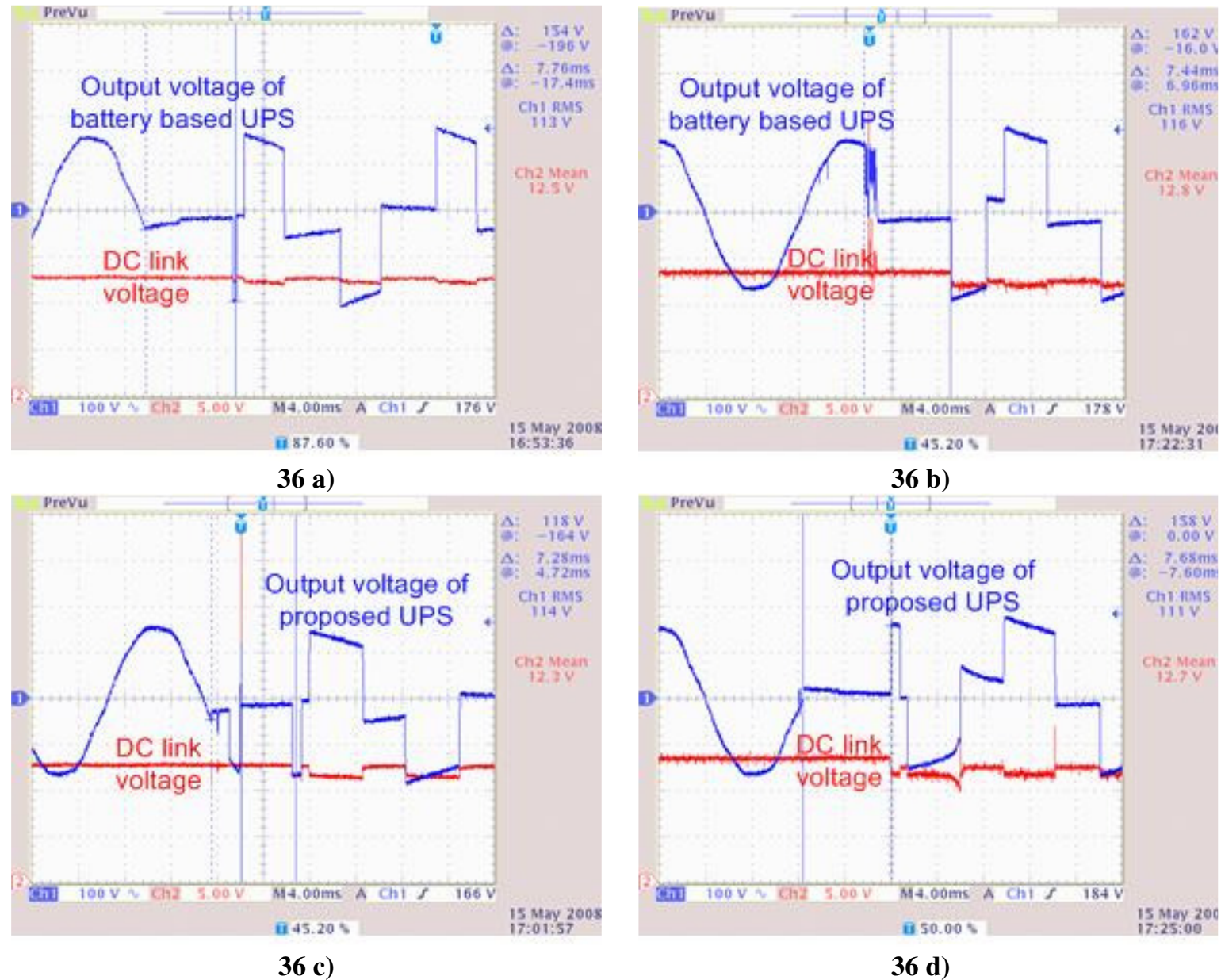

36 c)

$36 \mathrm{~d})$

Figure 36. Transfer time for a) battery based UPS system with $20 \mathrm{~W}$ load b) battery based UPS system with $100 \mathrm{~W}$ load c) proposed UPS system with $20 \mathrm{~W}$ load and d) proposed UPS system with $100 \mathrm{~W}$ load

The performance of the proposed UPS system is important and it must at least meet that of the battery based UPS system. One the important parameter is the transfer 
time from the utility power to the back-up power. This comparison was done and the results are shown in Figure 36. It can be seen from the results that the transfer for both battery based UPS system and the proposed UPS system are almost the same. The UPS mainly being for residential applications (like computers), less than $8 \mathrm{~ms}$ transfer time is lesser than the ride through time for the SMPS of a computer (10-20 ms).

The primary use of the proposed UPS system being for residential, mainly for computer back up, it must be ensured that there's no flickering of the monitor during the transfer from utility to back-up power source. This was also experimented on and it was observed that there was no flickering of the monitor when the source switched from the utility to the hybrid power source.

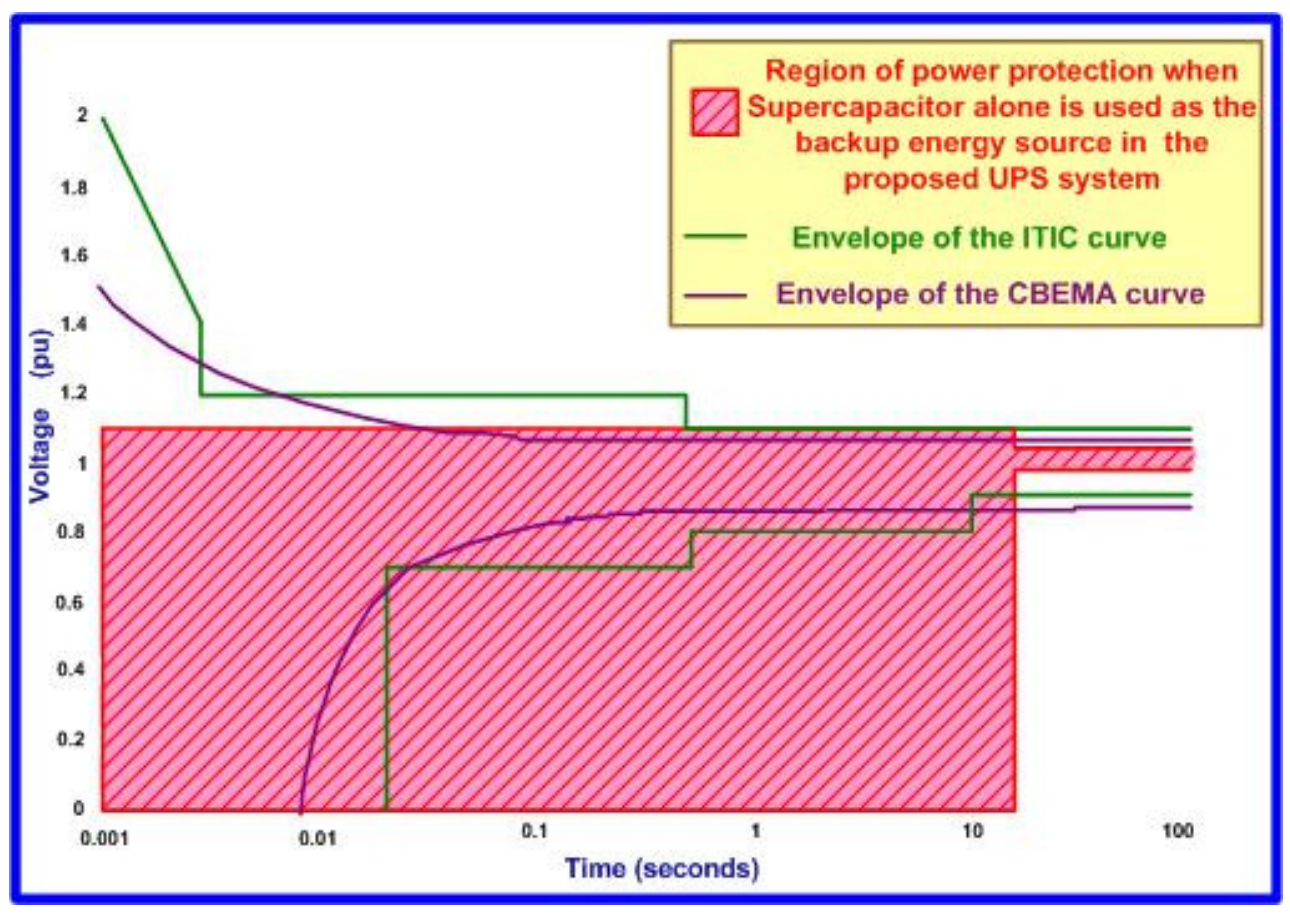

Figure 37. CBEMA - ITIC curve showing the region of operation of the proposed UPS system 
Another important result from these tests is that the region of protection of the proposed UPS system when supercapacitor bank is used as the backup power source has been increased as shown in Figure 37. This ensures that quality power is supplied to the load at all times. Also, this region of operation can be further reduced to $\pm 10 \%$ of the rms voltage throughout the time of operation if a On-line UPS was used instead of the Stand-by UPS (which has been used here).

\subsection{Conclusions}

This chapter focuses on experimental verification of the proposed UPS system and verification of its performance. The chapter starts out with the verification of the non linear model of the supercapacitor by applying step load changes and measuring the response times. It was proven that the capacitor energy storage capacity varies as a function of the voltage and hence proves to be advantageous during transients. Further, the advantage of having a hybrid source (supercapacitor in parallel with fuel cell) over just a stand alone fuel cell source was shown through fuel consumption data and temperature rise data. Finally, the transfer times for the proposed UPS system and the battery based UPS system were measured and were found to be satisfactory. Overall, the proposed system was found to satisfy the required performance specifications. 


\section{CHAPTER V}

\section{CONCLUSIONS}

The increasing dependence on electric power and the demand for not just continuous power supply also for quality power requires a power conditioner system. While aiming towards a reliable and quality backup system, another major factor to be considered is achieving this while remaining environmentally friendly; this cannot be realized with batteries and engine generators. Among various viable technologies the fuel cells have emerged as one of the most promising sources for both portable and stationary applications.

In this thesis, a new battery less UPS system configuration powered by fuel cell is discussed. The proposed topology utilizes a standard offline UPS module and the battery is replaced by a supercapacitor. The system operation is such that the supercapacitor bank is sized to support startup and load transients and steady state power is supplied by the fuel cell. Further, the fuel cell runs continuously to supply $10 \%$ power in steady state. In case of power outage, it is shown that the startup time for fuel cell is reduced and the supercapacitor bank supplies power till the fuel cell ramps up from supplying $10 \%$ load to $100 \%$ load. A detailed design example is presented for a 200W/350VA 1-phase UPS system to meet the requirements of a critical load. The equivalent circuit and hence the terminal behavior of the fuel cell and the supercapacitor are considered in the analysis and design of the system for a stable operation over a wide 
range. Experimental results along with stability analysis and efficiency calculations using a prototype is also shown for performance verification.

In this chapter, the test setup for fuel cell impedance modeling has been explained. Further, the equivalent circuit model for the fuel cell has been derived from the results obtained from the impedance model. Also, the modeling of supercapacitor has bee shown in detail. The Nyquist plots have been plotted from which the proposed equivalent model parameters are extracted. The variation of the supercapacitor capacitance and internal resistance with respect to voltage has been shown. Once the impedance modeling of the supercapacitor bank and fuel cell stack are done, the effect of interfacing them with the power converter circuits and the entire system can be analyzed using the Middlebrook's extra element theorem.

Chapter III started out with description of the block diagram of the proposed UPS system topology. A design example has been shown which gives the specifications of the proposed UPS system along with detailed specification of the Ballard Nexa fuel cell. A complete design example illustrating the amount of hydrogen storage required for 1 hour power outage and sizing of supercapacitors for transient load demand has been presented for a 200W/350 VA UPS. A method to size the supercapacitor module was incorporated to overcome the load transients such as instantaneous power fluctuations, slow dynamics of the fuel preprocessor and overload conditions. It was shown that the supercapacitor values calculated for overload conditions were sufficient to enhance stability and improve dynamic response of the fuel cell. The design of the buck converter used has been explained hence arriving at the output inductor and capacitor values. In 
addition, the necessity of the supercapacitor charging circuit and its topology has bee depicted. A mathematical approach to analyze the interactions between the internal impedance of the fuel cell and the dc-dc converter closed loop control to verify steady state and transient stability has been presented. Design inequalities have been reviewed to better understand the interaction between the DC-DC converter and fuel cell and, as well, potential instability conditions.

Finally, Chapter V focuses on experimental verification of the proposed UPS system and verification of its performance. The chapter starts out with the verification of the non linear model of the supercapacitor by applying step load changes and measuring the response times. It was proven that the capacitor energy storage capacity varies as a function of the voltage and hence proves to be advantageous during transients. Further, the advantage of having a hybrid source (supercapacitor in parallel with fuel cell) over just a stand alone fuel cell source was shown through fuel consumption data and temperature rise data. Finally, the transfer times for the proposed UPS system and the battery based UPS system were measured and were found to be satisfactory. Overall, the proposed system was found to satisfy the required performance specifications. 


\section{REFERENCES}

[1] Information Technology Industry Council (CBEMA) Curve, http://www. itic.org/archives/iticurv.pdf, Revised 2000.

[2] Arizona Public Service, "Power quality for business", http://www.aps.com/main/ _files/services/BusWaysToSave/Power.pdf, Accessed 2008.

[3] Merlin Gerin UPS, "MGE UPS standards and topologies", http://www.mgeups. com /techinfo/techpap/articles/0248-e.pdf, Accessed 2008.

[4] American Power Conversion UPS, "The different types of UPS systems", http://m.softchoice.com/files/pdf/brands/apc/The\%20Different $\% 20$ Types $\% 20$ of $\% 2$ 0UPS\%20Systems.pdf, Accessed 2008.

[5] Critical Power Resource, LLC, "Different types of UPS systems", www.criticalpowerresource.com/kindsofups.pdf, Accessed 2008.

[6] W. Fuglevand and R.E. Grant, "Ultracapacitors and fuel cells make a perfect match for portable applications", Portable Design, http://www.portabledesign.com /archive_article/17579, Jan 2004.

[7] A. F. Burke, "Batteries and ultracapacitors for electric, hybrid, and fuel cell vehicles", Proceedings of the IEEE, vol. 95, April 2007, pp. 806-820.

[8] M. Uzunoglu and M. S. Alam, "Dynamic modeling, design, and simulation of a combined PEM fuel cell and ultracapacitor system for stand-alone residential applications", IEEE Transactions on Energy Conversion, vol. 21, no. 3, pp 767 775, September 2006.

[9] M. Amrhein and P.T. Krein "Dynamic simulation for analysis of hybrid electric vehicle system and subsystem interactions, including power electronics", IEEE Transactions on Vehicle Technology, vol. 54, no. 3, pp. 825-836, May 2005.

[10] P. J. H. Wingelaar, J. L. Duarte and M. A. M. Hendrix, "PEM fuel cell model representing steady-state, small-signal and large-signal characteristics", Journal of Power Sources, vol. 171, issue 2, pp. 754-762, September 2007. 
[11] N. Fouquet, C. Doulet, C. Nouillant, G. Dauphin-Tanguy and B. OuldBouamamab, "Model based PEM fuel cell state-of-health monitoring via ac impedance measurements", Journal of Power Sources, vol. 159, issue 2, pp. 905913, September 2006.

[12] P. J. H. Wingelaar, J. L. Duarte and M. A. M. Hendrix, "Dynamic characteristics of PEM fuel cells", in IEEE $36^{\text {th }}$ Annual Power Electronics Specialists Conference, 2005, pp.1635-1641.

[13] R. F. Mann, J. C. Amphlett, M. A. I. Hooper, H. M. Jensen, B. A. Peppley and P. R. Roberge, "Development and application of a generalized steady-state electrochemical model for a PEM fuel cell", Journal of Power Sources, vol. 86, issues 1-2, pp. 173-180, March 2000.

[14] J.J. Baschuk and X. Li, "Modeling of polymer electrolyte membrane fuel cells with variable degrees of water flooding", Journal of Power Sources, vol. 86, issues 1-2, pp. 181-196, March 2000.

[15] M. Ceraolo, C. Miulli and A. Pozio, "Modeling static and dynamic behavior of proton exchange membrane fuel cells on the basis of electro-chemical description", Journal of Power Sources, vol. 113, no. 1, pp. 131-144, January 2003.

[16] W. Choi, P. Enjeti and J.W. Howze, "Fuel cell powered UPS systems: design considerations", in Thirty-fourth Annual IEEE Power Electronics Specialists Conference, vol. 1, June 2003, pp. 385 - 390.

[17] M. Ciureanu and R. Roberge, "Electrochemical impedance study of PEM fuel cells. Experimental diagnostics and modeling of air cathodes", J. Phys. Chem. B, vol. 105, issue 17, pp. 3531-3539, Jan 2001.

[18] L. Zubieta and R. Bonert, "Characterization of double-layer capacitors for power electronics applications", IEEE Transactions on Industry Applications, vol. 36, pp. 199-205, Jan/Feb 2000.

[19] J.R. Miller, "Development of equivalent circuit models for batteries and electrochemical capacitors", in Fourteenth Annual Battery Conference on Applications and Advances, 1999, pp. 107-109.

[20] W. Lajnef, J.-M. Vinassa, 0. Briat, S. Azzopardi and C. Zardini, "Study of ultracapacitors dynamic behavior using impedance frequency analysis on a specific test bench", in 2004 IEEE International Symposium on Industrial Electronics, vol. 2, May 2004, pp. 839- 844. 
[21] W. Lajnef, J.-M. Vinassa, O. Briat, S. Azzopardi and E. Woirgard, "Characterization methods and modeling of ultracapacitors for use as peak power sources", Journal of Power Sources, vol. 168, Issue 2, pp. 553-560, June 2007.

[22] Maxwell Technologies, Datasheet, BCAP0140 E250 BC Energy Series Boostcap Ultracapacitors, Maxwell Technologies, Inc, San Diego, CA, USA, http://www.maxwell.com/pdf/uc/datasheets/BC_Cell_Energy_1009473_rev3.pdf. Accessed 2008.

[23] R. Erickson and D. Maksimović, Fundamentals of Power Electronics, Second Edition, Massachusetts, Kluwer Academic Publishers, 2001.

[24] M. Pagano and L. Piegari, "Electrical networks fed by fuel cells for uninterruptible electrical supply," in ISIE 2002 Conf. Rec., vol.3, May 2002, pp.953-958.

[25] E. Santi, D. Franzoni, A. Monti, D. Patterson, F. Ponsi, and N. Barry, "A fuel cell based domestic uninterruptible power supply", in Twelfth Annual IEEE Applied Power Electronics Conference and Exposition, March 2002, pp. 605-613.

[26] F. Alessandro, V. Antonucci, L. Dusonchet, S. Favuzza, M. Ferraro and G. Graditi, "UPS fuel cell based: an innovative back-up system", in IEEE International Conference on Clean Electrical Power, 2007, pp.723-729.

[27] G. V. Sukumara, A. Parthasarathy and V. R. Shankar, "Fuel cell based uninterrupted power sources," in International Conference on Power Electronics and Drive Systems, vol. 2, May 1999, pp. 728 -733.

[28] N. Kato, T. Murao, K. Fujii, T. Aoiki and S. Muroyama, "1 kW portable fuel cell system based on PEFCs," in Third International IEEE Telecommunications Energy Special Conference, May 2000, pp. 209 -213.

[29] N. Myers and J. DeHaan, "Fuel cells: will fuel cells be replacing batteries at your facility?", Bureau of Reclamation, Denver, CO, USA, 2005.

[30] Ballard Power Systems Inc, NexaTM Power Module User's Manual MAN5100078, Burnaby, BC, Canada: Ballard Power Systems Inc, Oct. 2005.

[31] M.W. Chase Jr., NIST-JANAF Thermochemical Tables, 4th ed., Washington D.C: American Institute of Physics for the NIST, 1998.

[32] J.H. Dymond, and E.B. Smith, The Virial Coefficients of Pure Gases and Mixtures, A Critical Complication, Oxford: Oxford University Press, 1980. 
[33] J.M. Smith, H.C. Van Ness, and M.M. Abbott, Introduction to Chemical Engineering Thermo Dynamics, New York: McGraw-Hill, 1996.

[34] Maxwell Technologies, Appl Note 1007236, How to Determine the Appropriate Size Ultracapacitor for Your Application, Maxwell Technologies Inc, San Diego, CA, USA, 2004.

[35] Linear Technology, Datasheet, LT1339 High Power Synchronous DC/DC Controller, Linear Technology Corporation, Milpitas, CA, USA, 1997.

[36] Maxwell Technologies, Appl Note 1008981, Charging of Ultracapacitors, Maxwell Technologies Inc, San Diego, CA, USA, 2005.

[37] Maxwell Tecnologies, Appl Note 009, Roger Edelson, Charging Ultracapacitors with Current-Fed Power Supplies, Maxwell Technologies Inc, San Diego, CA, USA, Oct. 2006.

[38] Linear Technology, Datasheet, LT1725 General Purpose Isolated Flyback Controller, Linear Technology Corporation, Milpitas, CA, USA, 2000.

[39] Linear Technology, Design Note 260, Robert Sheehan, LT1725 Isolated Flyback Regulated without and Optocoupler, Linear Technology Corporation, Milpitas, CA, USA, 2001. 


\section{VITA}

Mirunalini Venkatagiri Chellappan received her Bachelors of Engineering degree in 2006 from College of Engineering, Guindy, Anna University, Chennai, India in Electrical and Electronics Engineering. She joined her Masters of Science degree in Electrical Engineering at Texas A\&M University, specializing in Power Electronics, in August 2006 and graduated in August 2008.

Her interests include power electronics especially UPS systems, converters for fuel cells, solar cells and energy storage devices.

She can be reached at vcmirunalini@gmail.com or vcm@numericups.com or

through Department of Electrical and Computer Engineering, Texas A\&M University, College Station, Texas 77840, mail stop 77843-3128. 